FUNÇÕES DE RESPOSTA DA LARANJA PÊRA

A IRRIGAÇÃO COMPLEMENTAR E NITROGÊNIO

ALTAIR BERTONHA

Engenheiro Agrônomo

Prof. Orientador : José Antonio Frizzone

PIRACICABA

Estado de São Paulo - Brasil

Março - 1997 
Dados Internacionais de Catalogação na Publicação (CIP) DIVISĀo DE BIBLIOTECA E DOCUMENTAÇĀO - Campus "Luiz de Queiroz"/USP

Bertonha, Altair

Funções de resposta da laranja pêra : a irrigação complementar e nitrogênio / Altair Bertonha. - Piracicaba, 1997.

113 p. : il.

Tese (doutorado) -. Escola Superior de Agricultura Luiz de Queiroz, 1997. Bibliografia.

1. Adubaçāo nitrogenada 2. Fertirrigação 3. Fruta citrica 4. Irrigação por microaspersāo 5. Laranja pêra I. Título 
FUNÇÕES DE RESPOSTA DA LARANJA PÊRA

A IRRIGAÇÃO COMPLEMENTAR E NITROGÊNIO

ALTAIR BERTONHA

Aprovada em 15.05.97.

Comissão julgadora:

Prof. Dr. José Antonio Frizzone

ESALQ-USP

Prof. Dr. Tarlei Arriel Botrel

ESALQ-USP

Prof. Dr. Marcos Vinicius Folegatti

ESALQ-USP

Prof. Dr. Jõao Carlos Cury Saad

UNESP

Prof. Dr. José Renato Zanini

UNESP

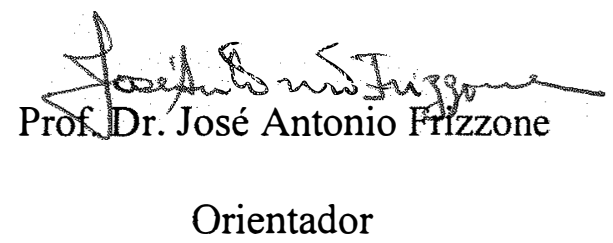




\section{DEDICO}

À minha esposa VITORINA e a meus filhos

LEONARDO, LEANDRO e LETICIA

pelo incentivo, apoio e compreensão. 
AGRADECIMENTOS

Ao Prof. Dr. José Antonio Frizzone e família, pelo apoio e amizade;

Aos professores do departamento de Engenharia Rural da ESALQ: Prof. Dr. Décio Eugenio Cruciani, Prof. Dr. Hugo Ghelfi Filho, Prof. Dr. Tarlei Arriel Botrel, Prof. Dr. Marcos Vinicius Folegatti e Prof. Dr. Antônio Sanchez de Oliveira.

Ao Prof. Elias Nunes Martins pela ajuda na definição do delineamento e análise estatística;

Aos colegas e amigos de curso: Vital, Tangerino, Vanglesio e Tharga;

Aos colegas da Universidade Estadual de Maringá: Prof. Roberto, Prof. Antônio e Prof. Paulo. 


\section{SUMÁRIO}

Pág.

RESUMO Xvi

SUMMARY Xvi

1. INTRODUÇÃO 1

2. REVISÃO DE LITERATURA 4

2.1. Efeito da água no solo sobre o vegetal e os fatores que afetam a absorção 5

2.2. Água e nitrogênio no sistema solo-planta-atmosfera 9

2.2.1. Disponibilidade de água no solo 10

$\begin{array}{ll}\text { 2.2.2. Disponibilidade de nitrogênio } & 11\end{array}$

2.3. A interação planta-atmosfera 13

2.4. Efeitos da água e do nitrogênio na produção dos citrus 15

2.5. Função de resposta das culturas $\quad 22$

$\begin{array}{lll}2.6 & \text { Funções de custo e receita } & 27\end{array}$

3. MATERIAL E MÉTODOS 30

3.1. Localização e caracterização da área 30

3.2. Práticas culturais 33 
3.3. Delineamento experimental 34

3.4. Tratamentos 35

3.5. Adubação nitrogenada 35

3.6. Controle de irrigação 37

3.7. Parâmetros avaliados 41

3.8. Funções de resposta da laranjeira $\quad 44$

3.9. Preços da laranja 46

3.10. Custo de produção de laranja 46

3.10.1. Custo da irrigação 46

3.10.2. Custo do pomar 51

3.10.3. Custo do nitrogênio 54

3.10.4. Custo da colheita $\quad 54$

4. RESULTADOS E DISCUSSÃO 55

4.1. Número de frutos durante o ciclo de produção 55

4.2. Número de frutos colhidos por árvore $\quad 59$

4.3. Peso médio do fruto na colheita 65

4.4. Caixas de frutos produzidos por árvore $\quad 69$

4.5. Produção de suco por fruto 75

4.6. Volume de suco produzido por árvore $\quad 79$

4.7. Sólidos solúveis produzidos por fruto (brix) 83

4.8. Sólidos solúveis produzidos por árvore 86 
4.9. Análise econômica do experimento 90

4.9.1. Custo da irrigação 90

4.9.2. Custo anual do pomar 93

$\begin{array}{ll}\text { 4.9.3. Receitas } & 94\end{array}$

5. CONCLUSÕES 97

6. REFERÊNCIAS BIBLIOGRÁFICAS 99 


\section{LISTA DE TABELAS}

TABELA

Pág.

1 Analise química e granulométrica do solo

2 Valores mensais de evaporação do tanque classe A (ECA), precipitação (PREC), diferença entre evaporação e precipitação (ECA-PREC), número de irrigações (Ni), intervalo entre irrigações (I) e lâmina de irrigação aplicada por parcela (Wi)

3 Tarifas de energia elétrica para uso rural, oferecidas pela CPFL

4 Despesas anuais de implantação do pomar $\left(1 .^{\circ}\right.$ ao $4 .^{\circ}$ ano) e de custeio $\left(5 .^{\circ}\right.$ e $6 .^{\circ}$ anos $)$

5 Valor do investimento para implantação do pomar (R $\$$ /árvore)

6 Valores médios do número de frutos colhidos por árvore

7 Análise de variância dos tratamentos e seus desdobramentos, da regressão e dos coeficientes da regressão para número de frutos colhidos por árvore

$8 \quad$ Valores médios do peso do fruto (g.)

9 Análise de variância dos tratamentos e de seus desdobramentos, da regressão e dos coeficientes da regressão para peso do fruto. 
10 Número de caixas de frutos (40,8 $\mathrm{kg}$ de frutos) produzidos por árvore 70

11 Análise de variância dos tratamentos e seus desdobramentos, da regressão e dos coeficientes da regressão para caixas de frutos produzidos por árvore $\quad 72$

12 Valores médios do volume de suco produzido por fruto $(\mathrm{ml}) \quad 76$

13 Análise de variância dos tratamentos e seus desdobramentos, da regressão e dos coeficientes da regressão para volume de suco produzido por fruto

14 Volume de suco produzido (l/árvore) $\quad 80$

15 Análise de variância dos tratamentos e seus desdobramentos, da regressão e dos coeficientes da regressão para volume de suco produzido por árvore

16 Sólidos solúveis produzidos por fruto $(\%)$

17 Análise de variância dos tratamentos e seus desdobramentos, da regressão e dos coeficientes da regressão para teor de sólidos solúveis contidos nos frutos

18 Sólidos solúveis produzidos por árvore $(\mathrm{kg}) \quad 86$

19 Análise de variância dos tratamentos e seus desdobramentos, da regressão e dos coeficientes da regressão para sólidos solúveis produzidos por árvore 
21 Custo anual da energia elétrica para as várias opções de tarifas oferecidas pela CPFL, em função dos volumes de irrigação utilizados no experimento

22 Volumes de irrigação, custos fixos, variáveis e totais (R \$árvore), durante o ciclo de produção

23 Custo anual do pomar, por árvore, no $5^{\circ}$ ano (R\$árvore)

24 Custo total do pomar no $5^{0}$ ano, por árvore (R \$árvore) 94

25 Receita bruta por árvore, frutos para consumo in natura $(\mathrm{R} \$ 3,00 / \mathrm{cx}) \quad 95$

26 Receita líquida por árvore, para o mercado de frutos in natura. (R\$árvore) 


\section{LISTA DE FIGURAS}

FIGURA

Pág.

1 Representação esquemática de uma função de produção tendo a água como fator variável

2 Representação esquemátiça de funções de (a) receita bruta, (b) custo e (c) receita líquida

3 Curva de retenção de água no solo

4 Médias mensais da evaporação do tanque classe A, precipitação e temperatura média para os anos de 1980 a 1995.

5 Médias mensais da evaporação do tanque classe A, precipitação e temperatura média para o período do experimento (julho de 1995 a junho de 1996).

6 Diagrama esquemático da área experimental

7 Evapotranspiração da cultura acumulada entre irrigações, precipitação pluvial e irrigações no período de julho a dezembro de 1995.

8 Evapotranspiração da cultura acumulada entre irrigações, 
precipitação pluvial e irrigações no período de janeiro a junho de 1996.

9 Médias por tratamento, do número de frutos por árvore, no final do florescimento (agosto de 1995), no final da frutificação (setembro de 1995) e na colheita ( julho de 1996), em função dos volumes de água aplicados por irrigação

10 Médias por tratamento do número de frutos por árvore, no final do florescimento (agosto de 1995), no final da frutificação (setembro de 1995) e na colheita (julho de 1996), em função das doses de nitrogênio aplicadas semanalmente

11 Superficie de resposta para número de frutos colhidos em função da irrigação e adubação nitrogenada

12 Curvas de isoprodução para número de frutos colhidos em função da irrigação e adubação nitrogenada

13 Superficie de resposta para o peso médio de fruto em função da irrigação e adubação nitrogenda

14 Superfície de resposta para número de caixas de frutos por árvore em função da irrigação e adubação nitrogenada

15 Curvas de isoprodução para número de caixas de frutos por árvore em função da irrigação e adubação nitrogenada 
16 Superfície de resposta para volume de suco produzidos por árvore em função da irrigação e adubação nitrogenada.

17 Curvas de isoprodução para volume de suco produzidos por árvore em função da irrigação e adubação nitrogenada

18 Superfície de resposta para sólidos solúveis produzidos por árvore, em função da irrigação e adubação nitrogenada

19 Curvas de isoprodução para sólidos solúveis produzidos por árvore em função da irrigação e adubação nitrogenada

20 Custo da irrigação em função dos níveis de irrigação, em R\$/árvore

21 Isoquantas de receita líquida em função da irrigação e adubação nitrogenada 


\title{
FUNÇÕES DE RESPOSTA DA LARANJA PÊRA \\ A IRRIGAÇÃO COMPLEMENTAR E NITROGÊNIO
}

\author{
Autor: ALTAIR BERTONHA \\ Orientador: Prof. Dr. JOSÉ ANTONIO FRIZZONE
}

RESUMO

Com o objetivo de estudar o efeito da irrigação e adubação nitrogenada no rendimento econômico e nos componentes de produção da laranja (Citrus sinensis Osbeck vr. Pêra), conduziu-se um experimento no Centro Técnico de Irrigação da Universidade Estadual de Maringá, Maringá, PR. O delineamento experimental foi inteiramente casualizado, com sete níveis de irrigação complementar $\left(\mathrm{W}_{0}=0, \mathrm{~W}_{1}=1440, \mathrm{~W}_{2}=2880, \mathrm{~W}_{3}=4320\right.$, $\mathrm{W}_{4}=5760, \mathrm{~W}_{5}=7200$ e $\mathrm{W}_{6}=86401$ de água/árvore $)$ e seis de nitrogênio $\left(\mathrm{N}_{0}=0, \mathrm{~N}_{1}=\right.$ 107,5, $\mathrm{N}_{2}=215, \mathrm{~N}_{3}=322,5, \mathrm{~N}_{4}=430$ e $\mathrm{N}_{5}=537.5 \mathrm{~g}$ de N/árvore). A irrigação foi realizada por microaspersão e controlada em função da evapotranspiração da cultura (Etc), estimada pelo tanque "Classe A". Aplicou-se água sempre que Etc acumulada entre irrigações atingiu 7,3 mm. Para adubação nitrogenada usou-se uréia diluída em 
água, parcelada em 43 aplicações, com freqüência semanal. Os resultados permitiram as seguintes conclusões:

- O número de frutos, caixas de frutos, volume de suco e sólidos solúveis por árvore descrevem uma relação quadrática em função do volume de água aplicada e da adubação nitrogenada.

- O peso médio do fruto descreve uma relação quadrática para nitrogênio e linear para água.

- O número de caixas de frutos produzidas por árvore tem maior relação com o número de frutos por árvore que com o peso médio do fruto.

- Níveis adequados de irrigação e adubação nitrogenada possibilitam o aumento simultâneo do número de frutos por árvore e do peso médio do fruto.

- Aplicação de doses crescentes de nitrogênio aumenta o volume de suco por fruto e diminuiu o teor de sólidos solúveis.

- Teores de sólidos solúveis superiores a 10\% são obtidos com doses de nitrogênio menores que 337 g/árvore, independente do volume de irrigação complementar.

- O volume de suco produzido por árvore apresenta maior correlação com o número de frutos que com volume de suco por fruto.

- Irrigação complementar e adubação nitrogenada em níveis adequados favorecem a obtenção de receitas líquidas positivas em pomares de cinco anos, produzindo frutos para consumo in natura. 


\title{
RESPONSE FUNCTIONS OF ORANGE PÊRA \\ TO SUPPLEMENTAL IRRIGATION AND NITROGEN
}

\author{
Author: ALTAIR BERTONHA \\ Adviser: Prof. Dr. JOSÉ ANTONIO FRIZZONE
}

SUMMARY

An experiment was conducted at the Centro Técnico de Irrigação of the State University of Maringá, in Maringá, PR, Brasil, in order to study the effect of irrigation and nitrogen fertilization on the economic yield and orange (Citrus sinensis Osbeck vr. Pêra) production elements. The experimental design was entirely randomized with seven rates of supplemental irrigation $\left(\mathrm{W}_{0}=0, \mathrm{~W}_{\mathrm{l}}=1440, \mathrm{~W}_{2}=2880, \mathrm{~W}_{3}=4320, \mathrm{~W}_{4}=5760, \mathrm{~W}_{5}\right.$ $=7200$, and $\mathrm{W}_{6}=8640 \mathrm{l}$ water/tree $)$ and six rates of nitrogen $\left(\mathrm{N}_{0}=0, \mathrm{~N}_{1}=107.5, \mathrm{~N}_{2}=\right.$ $215, \mathrm{~N}_{3}=322.5, \mathrm{~N}_{4}=430$, and $\mathrm{N}_{5}=537.5 \mathrm{~g} \mathrm{~N} /$ tree). Irrigation through a microsprinkler was performed and controlled according to the evapotranspiration of the crop, and estimated by a "Class A" pan. Water was applied whenever the evapotranspiration reached 7,3 $\mathrm{mm}$. For the nitrogen fertilization water-diluted urea divided into 48 applications at a weekly rate. The results allowed the following conclusions: 
- The number of fruits, boxes of fruits, juice volume, and soluble solids per tree increased with the irrigation volume and nitrogen fertilization, according to a quadratic relationship.

- The average fruit weight increases with the irrigation volume and nitrogen rates, according to a quadratic relationship for the nitrogen and linear relationship for the water.

- The number of boxes of fruits produced per tree has higher correlation with the number of fruits than with the average fruit weight.

- Adequate irrigation and nitrogen fertilization rates provide increased number of fruits per tree and average fruit weight simultaneously.

- The application higher rates of nitrogen produces increased juice volume per fruit and soluble solid contents.

- Soluble solid contents above $10 \%$ are obtained with nitrogen rates below $337 \mathrm{~g} /$ tree, disregarding the volume of the supplemental irrigation.

- The volume of juice produced per tree presents higher correlation with the number of fruits than with juice volume per fruit.

- Supplemental irrigation and nitrogen fertilization at adequate rates provide positive net revenue in five-year orchards, thus producing fruits for in natura consumption. 


\section{INTRODUÇÃO}

No panorama mundial de produção de frutas, a laranja ocupa o primeiro lugar com valores oscilando entre 50,7 e 57,8 milhões de toneladas por ano, seguida pela uva, com valores semelhantes e depois pela banana e maçã com valores em torno de 40 milhões de toneladas anuais cada uma, segundo FAO (1995).

Dos 57,8 milhões de toneladas de laranja produzidas no mundo no ano de 1995, 19,6 milhões de toneladas (33,9\%) foram produzidas no Brasil, em uma área de 895,8 mil hectares de pomares produtivos. Estima-se a produção média dos pomares brasileiros em $21.880 \mathrm{~kg} / \mathrm{ha}$ (FAO, 1995).

Da produção brasileira de laranja, 70\%, são destinadas para a indústria de extração de suco, sendo que este suco é na sua maioria exportado (Iannini, 1992). O restante dos frutos é destinado ao mercado de frutos frescos, tanto para consumo in natura, quanto para sucos frescos.

Como a perspectiva mundial de consumo de suco de laranja é crescente, principalmente porque estão sendo abertos novos mercados de consumo (Japão, China e Rússia) além de estarem sendo estimulados os mercados tradicionais a consumirem mais 
suco, pode-se considerar que, a médio prazo, esteja assegurado a comercialização da laranja produzida, segundo Garcia (1993).

Apesar da demanda ser crescente, o preço da caixa de frutos $(40,8 \mathrm{~kg})$ destinado à indústria de suco, tende a permanecer estável nos próximos anos, entre US\$ 1,5 e US\$ 2,0, passando para patamares mais altos somente se ocorrer frustração na safra americana (Garcia, 1993). Por outro lado os frutos destinados ao consumo in natura, apresentaram no último ano uma variação de preço no período de safra, entre US $\$ 1,50$ a US $\$ 3,50$ por caixa.

Considerando o peço da caixa e a produtividade média dos pomares brasileiros (2,0 caixa/árvore), a renda bruta desta atividade tende a se estabilizar entre US $\$ 3,00$ e US\$ 7,00 por árvore por ciclo de produção quando as despesas são de US\$2,72 para o quinto ano de produção e de US\$ 3,04 por árvore para o sexto ano em diante em pomares de 360 árvores/ha (COCAMAR-CITRUS $\left.{ }^{1}, 1997\right)$.

Para aumentar a renda desta atividade o produtor de laranja pode atuar na produção física, na produção de suco e nos teores de sólidos solúveis, buscando também a redução dos custos operacionais da cultura. Isto somente poderá ser feito se ele tiver consciência da importância dos efeitos dos parâmetros de produção, tais como: populações de plantas, controle de pragas, doenças e invasoras e época de colheita. Para fazer frente à estes problemas, o produtor de laranja dispões de técnicas como contrôle

'COCAMAR-CITRUS - Custo de implantação e produção de pomares de laranja para a região de Maringá PR, no ano de 1997. 
fitossanitário da lavoura, adubação e irrigação e a utilização de cultivares mais produtivos e resistentes de laranja e de porta enxerto

Considerando que há três mercados distintos para o fruto (indústria, frutas para consumo in natura e frutas para consumo na forma de suco fresco), o produtor de laranja deve definir níveis de insumos que atenda as exigências do mercado que pretende atingir, em função do preço de cada um destes mercados no momento de venda.

Como a laranja é uma fruta de produção sazonal, Sua produção deve ser projetada para ocorrer nas épocas de melhor preço histórico. Para isto a irrigação, pode suprir a possível deficiência hídrica no período de floração e durante o crescimento dos frutos.

O objetivo deste trabalho foi obter funções de respostas associadas a produção de laranja (Citrus sinensis Osbekc vr. PERA) em função de níveis de água e nitrogênio, para que, por meio de análise de superfície de resposta, seja possível definir as melhores alternativas de manejo, visando racionalizar a produção. Também buscou-se obter informações de alguns parâmetros de importância econômica (número de frutos, quantidade de sólidos solúveis e de suco, produzidos por unidade de fruto e por unidade de árvore além do peso unitário de frutos) em função dos níveis de água e nitrogênio aplicados. 


\section{REVISÃO DE LITERATURA}

A maioria das espécies do gênero Citrus são originárias de regiões tropicais úmidas do sudeste asiático, mais propriamente entre o sudeste da China e o sul da Índia. No entanto estas plantas têm como característica principal a boa adaptação aos períodos de déficit hídrico, ou mesmo a climas de deserto. Dentre as formas de adaptação pode-se citar o fechamento dos estômatos, a queda de folhas e a redução da taxa de crescimento, tanto da parte aérea como das raízes (Castro, 1994; Giorgi et al., 1991 e Marsh, 1968).

Por outro lado, o déficit hídrico no solo, combinado com temperaturas baixas, ou mesmo isoladamente, pode estimular o processo de florescimento da planta, provocar aumento do teor de sólidos solúveis nos frutos, além de antecipar a maturação dos mesmos (Castro, 1994; Giorgi et al., 1991).

Assim, conhecendo-se o efeito do déficit hídrico sobre esse vegetal, bem como sua demanda de água nas diferentes fases do ciclo de produção, além das características do solo e do clima local, pode-se atuar sobre esses fatores com o propósito de alterar o crescimento da planta, a produção de frutos, a qualidade dos frutos colhidos, a época de produção, bem como sobre o manejo de pragas e doenças no pomar (Castro, 1994). 
2.1. O efeito da água no solo sobre o vegetal e os fatores que afetam a absorção

O sistema radicular é a estrutura física que dá suporte para as plantas, funcionando como fundação para que o vegetal possa permanecer sobre o solo. Além disso, desempenha importantes atividades fisiológicas, tanto na síntese de fitohormônios como na função de absorver a solução do solo. Estas atividades, por sua vez, são moduladas pelos fatores que afetam a respiração, tais como, taxa de oxigênio e temperatura do solo, que também atuam como reguladores na disponibilidade de íons, na toxidez e na presença de patógenos no solo. Por ouro lado, tanto a temperatura quanto a taxa de difusão de oxigênio e a sua quantidade são influenciadas pela umidade do solo (Magalhães, 1988; Labanauskas et al., 1966 e Marsh, 1968).

A disponibilidade de oxigênio no solo, está diretamente relacionada com o acúmulo de matéria seca nas plantas, atuando sobre a emissão de radicelas, sendo substancialmente menor a concentração de radicelas, quanto menos oxigênio estiver disponível (Maza e Vitti, 1994; Labanauskas et al., 1966). Se, por um lado, a umidade excessiva no solo causa redução na disponibilidade de oxigênio, a redução desta não causa danos ao sistema radicular das plantas cítricas; esse simplesmente para de crescer, reduzindo a sua atividade na medida em que a deficiência hídrica for aumentada, voltando a desenvolver esta atividade quando o solo novamente for umedecido (Marsh, 1968). 
A necessidade de oxigênio no solo não está relacionada apenas com a demanda vegetal, mas também com a necessidade dos microorganismos e com a oxidação de matéria orgânica. A sua disponibilidade, é função da temperatura, da ocupação dos poros por água e da compactação. A redução da quantidade de oxigênio é intensificada quando a umidade do solo se aproxima da saturação. Também a temperatura tem uma relação direta com a disponibilidade e demanda de oxigênio no solo, pois o aumento desta causa um aumento de consumo de oxigênio para a oxidação de matéria orgânica e para a respiração da flora microbiana do solo. Isto faz com que haja maior demanda por oxigênio no verão do que no inverno (Marsh, 1968).

A temperatura do solo também afeta diretamente o crescimento das raízes das plantas, particularmente do gênero Citrus, sendo de $20{ }^{\circ} \mathrm{C}$ a $34{ }^{\circ} \mathrm{C}$ o intervalo adequado para o crescimento das raízes e $20{ }^{\circ} \mathrm{C}$ a temperatura ideal (Giriton, 1927). Fora desse intervalo, o crescimento é insignificante.

As radicelas dos citrus encontram-se num extrato muito superficial do solo. Segundo Moreira (1988) 45,46\% das radicelas de árvores de citrus adultas estão distribuídas em até $15 \mathrm{~cm}$ de profundidade, $59,36 \%$ em até $30 \mathrm{~cm}$ e 73,12\% em até 60 cm. Observa-se que a água como regulador térmico, passa a ter maior importância para estas plantas do que para aquelas de sistemas radiculares mais profundos.

March. (1968) observou que o efeito da temperatura pode suplantar o efeito do déficit de água em plantas cítricas. Relatou que em um experimento onde a freqüência de irrigação ideal era de duas semanas, foi observado que freqüências de irrigações maiores 
apresentavam um efeito mais promissor para o crescimento das plantas, devido a redução gradual da temperatura do solo. Este efeito da água sobre a temperatura do solo deixava de existir em 10 dias e, portanto, o intervalo de duas semanas, apesar de ser hidricamente adequado, permitia que o solo ficasse exposto a temperaturas maiores à medida que a umidade reduzia.

Além da temperatura e da disponibilidade de oxigênio, a umidade também causa influência sobre o ciclo de vida dos microorganismos do solo, como sugere Feichtenberger (1990), quando afirma que para completar o ciclo de vida o Phitophora requer uma flutuação na umidade do solo. Os esporos do Phitophora nicotianae variedade Parasitica germinam rapidamente e produzem esporângeos em temperatura elevada, quando o solo está úmido. Os zoósporos, contudo, são formados e liberados dos esporângios quando o solo está saturado de água. Isto sugere que os esporângeos são produzidos após cada chuva ou irrigação, quando o solo começa a perder água e que os zoósporos somente são liberados após as chuvas ou as irrigações seguintes.

Pomares irrigados por gotejamento ou por microaspersão, em geral são menos sujeitos a problemas de Phitophora que aqueles irrigados por aspersão convencional e estes menos sujeitos que aqueles irrigados por superfície. Nos sistemas de irrigação localizada o solo permanece por mais tempo a uma umidade alta dificultando a frutificação do fungo. Também um menor volume de solo fica saturado e com isto um menor volume de propágulos passa a ser produzido devido a irrigação (Feichtenberger, 1990). 
No entanto, ao se discutir o efeito do manejo da água sobre os microorganismos do solo, é importante salientar que há também microorganismos fundamentais para a produção vegetal, como aqueles que atuam sobre a fixação e decomposição do nitrogênio, colocando-o de forma disponível para as plantas (Malavolta e Violante Neto, 1988).

A manutenção da atividade fisiológica e metabólica dos tecidos que compõem o sistema radicular dependem, também, do funcionamento harmônico das diferentes partes das plantas, principalmente das folhas, pois estas são responsáveis pelos processos de produção de carbohidratos, aminoácidos e outros compostos carbônicos sintetizados na fotossíntese, responsáveis pela manutenção e crescimento das plantas (Magalhães, 1988).

A água é o elemento fundamental para o desenvolvimento das raízes das plantas de citrus, no entanto, a extensão do seu efeito no crescimento das raízes e da planta como um todo, depende de como é aplicada, da permeabilidade do solo regularmente molhado, de suas condições físicas relacionadas com o movimento da água, da temperatura do solo e da água e da interação entre aeração e disponibilidade de água para a planta, além da interação entre estes fatores e a necessidade hídrica da planta nos diferentes estádios fenológicos (Marsh,1968).

Havendo água disponível, o sistema radicular dos citrus cresce continuamente devido a absorção e acumulação da água nos vacúolos das células, promovendo o alongamento das raízes e assim, causando o crescimento em volume deste órgão. 
Simultaneamente, compostos carbônicos metabolizados são transportados das folhas e depositados como macromoléculas, constituindo-se nos elementos estruturais dos tecidos das raízes. Além disso, os carbohidratos que chegam às raízes são utilizados como substratos para a manutenção dos processos de respiração e produção de energia metabólica, essenciais para a sustentação da absorção ativa dos elementos do solo (Hilgeman, 1977).

Para uma planta adulta, os processos que causam a maior demanda por nutrientes e água são o florescimento e a frutificação, fazendo com que haja um aumento das atividades metabólicas das folhas, responsáveis pela produção dos compostos orgânicos. Principalmente nessa fase, a preservação do sistema radicular em pleno funcionamento é importante para se conseguir, tanto a geração como a fixação de um maior número de frutos (Giorgi et al, 1991; Rodriguês, 1980 e Villiers, 1969).

2.2. Água e nitrogênio no sistema solo-planta-atmosfera

A água assume importância fundamental na produção vegetal, de modo que sua falta ou excesso afetam decisivamente o desenvolvimento da planta, e, por isso, seu manejo é essencial para a maximização da produção agrícola. Segundo Lima (1993), com o aparecimento das doenças podridão floral e CVC (Clorose variegada de citrus), a irrigação passou a ter novos enfoques, uma vez que pode adiantar a florada dos citrus, diminuindo os riscos com o colletotrichum e amenizar os efeitos da deficiência hídrica 
causada pela CVC. Além disso, a irrigação é a única prática cultural que, aplicada ao pomar, pode rapidamente aumentar, significativamente, a produção de sólidos solúveis por hectare pela uniformização da florada. Em vista disso, os estudos sobre irrigação devem ser continuados e analisados sob todos os aspectos, inclusive sobre a longevidade dos pomares.

Tubelis (1995) também recomenda que os pomares devem ser irrigados, principalmente nos meses de seca, com o propósito de concentrar a florada e, consequentemente, a produção. Salienta que, quanto mais uniforme forem as floradas, menor será o custo de manejo e maior será a produção de frutos viáveis, além de uniformizar as condições dos frutos na colheita.

O nitrogênio é considerado essencial devido a função estrutural que exerce na vida da planta (aminoácidos, proteínas, bases nitrogenadas, ácidos nucleicos, enzimas e coenzimas), participando de processos vitais em seu desenvolvimento. A alta exigência de nitrogênio pela cultura, também confirma essa informação (Malavolta et al, 1984).

\subsubsection{Disponibilidade de água no solo}

O conceito de disponibilidade de água no solo para plantas baseia-se em sua mobilidade. Quando a demanda de água da planta e da atmosfera é suprida pela intensidade de fluxo de água do solo para a raiz, diz-se que a água está disponível para a planta. No entanto a planta entra em condição de déficit hídrico quando o fluxo deixa de 
suprir esta demanda (Reichardt, 1985). O efeito do déficit hídrico no vegetal é um processo que envolve os efeitos hidráulicos dentro de cada um dos seus órgãos, particularmente na condutância das folhas combinado com alterações químicas que intensificam a síntese do etileno que irá determinar a queda de folhas. Havendo a abscisão, ocorrerá uma redução da superfície foliar, reduzindo assim a perda de água pelo vegetal por evapotranspiração, causando um aumento do potencial hídrico das folhas remanecentes (Castro, 1994).

\subsubsection{Disponibilidade de nitrogênio}

A região do sistema radicular mais ativa nos processos de absorção hídrica e iônica, está nos extremos das raízes e constitui-se dos pêlos absorventes. Nessa região da raiz há uma combinação do aumento da superfície de contato com o solo na parte externa juntamente com uma maior diferenciação do xilema na parte interna (Magalhães, 1988).

$\mathrm{O}$ nitrogênio é absorvido pelas plantas em duas formas: nítrica $\left(\mathrm{NO}_{3}^{-}\right)$e amoniacal $\left(\mathrm{NH}_{4}^{+}\right)$. A primeira é a mais comum, sendo fracamente retida pelos coloides do solo e, por conseqüência, está mais sujeita ao processo de perda por lixiviação. A amônia proveniente do fertilizante ou da mineralização da matéria orgânica pode ser absorvida pelas plantas ou microorganismos, adsorvida ao solo ou transformada em nitritos $\left(\mathrm{NO}_{2}^{-}\right)$e nitrato $\left(\mathrm{NO}_{3}^{-}\right)$, por nitrificação (Coelho, 1987). 
A intensidade da lixiviação depende, principalmente da quantidade de nitrogênio aplicada, da intensidade de precipitação, da taxa de infil ração da água, da evapotranspiração, da capacidade de retenção de água no solo e da taxa de absorção de nitrogênio pela cultura (Coelho et al., 1991).

A quantidade de água drenada tem sido identificada como um importante fator de influência na lixiviação de $\mathrm{NO}_{3}^{-}$(Smika, 1977; Peres e Suhet, 1986). Quando o volume drenado é aumentado, a quantidade total de $\mathrm{NO}_{3}^{-}$lixiviado aumenta concomitantemente. Portanto, uma forma de reduzir a lixiviação é diminuindo o excesso de água aplicada, desde que não aumente a salinização do solo.

O manejo do fertilizante nitrogenado é outra variável importante no aumento da lixiviação de $\mathrm{NO}_{3}^{-}$. Aplicações além da quantidade requerida para a produção máxima aumentam o potencial de lixiviação. Isto enfatiza a importância da determinação do nível ótimo de adubação nitrogenada, para um dado sistema de cultivo (Stark, et al., 1983). Contudo, a disponibilidade de $\mathrm{N}$ em terras irrigadas é vinculada ao manejo de água, sendo necessário identificar práticas de manejo que minimizem as perdas de $\mathrm{NO}_{3}^{-}$por percolação profunda, sem sacrificar a produção e/ou a qualidade da cultura.

Brito (1988) determinou os teores de $\mathrm{NH}_{4}^{+}$e $\mathrm{NO}_{3}^{-}$nas camadas 0-20, 20-40 e 40$60 \mathrm{~cm}$, de um solo de cerrado cultivado com trigo para verificação da ocorrência de lixiviação de nitrogênio. Não foi observada evidência de lixiviação relevante, pois o nitrogênio permaneceu nas camadas de 0 à $40 \mathrm{~cm}$, mesmo em parcelas que receberam as 
maiores lâminas $(1058 \mathrm{~mm})$ e altas doses de $\mathrm{N}(240 \mathrm{~kg} / \mathrm{ha})$. Constatou-se uma maior ocorrência de $\mathrm{NO}_{3}^{-}$à medida que aumentou a lâmina de água, indicando uma tendência para a predominância do nitrato, em vez de amônia, nos casos onde a irrigação é maior.

Uma estimativa do índice de lixiviação do nitrato em um Latossolo Vermelho Escuro, foi dada por Peres e Suhet (1986), como sendo de 1,3 $\mathrm{mm}$ através do perfil do solo, por milímetro de precipitação.

Rodrigues (1980) e Malavolta (1988) relatam que as plantas de citrus tem duas épocas preferenciais para aplicação de nitrogênio. A primeira, denominada de primavera quando há emissão de folhas e flores (julho-setembro) e a segunda, denominado de verão quando são emitidos somente folhas (dezembro-fevereiro).

\subsection{A interação planta-atmosfera}

A grande variabilidade temporal das chuvas, principalmente no outono e inverno determinam a desuniformidade de ocorrência de eventos fenológicos que afetam, a produção e a qualidade dos frutos das plantas cítricas (Giorgi et al, 1991).

As plantas cítricas não respondem ao fotoperíodo para a floração, sendo o regime termopluviométrico responsável pela ocorrência de floradas, o que leva muitas vezes a ocorrer mais de uma florada por ano. A interação dos fatores temperatura e disponibilidade hídrica para a planta desencadeiam reações metabólicas relacionadas 
com o balanço entre carbohidratos e nitrogênio que são os substratos para a síntese metabólica, juntamente com os hormônios vegetais (Giorgi et al, 1991).

O efeito, tanto de temperaturas baixas, como de seca, pode desencadear o processo reprodutivo que culmina com a floração. No entanto em condições de deficiência hídrica, é a temperatura que atua predominantemente na sensibilização da planta (Tubelis e Salibe, 1991).

Após o término da floração, inicia-se o crescimento dos frutos. Nesse período, a planta apresenta alta taxa respiratória (meses de agosto a janeiro), e tanto na fase de início de frutificação, como na fase final de formação dos frutos, a queda desses, decorrente de choques térmicos e principalmente de déficit hídrico no solo, pode ser determinante para a produção (Marsh, 1968; Tubelis e Salibe, 1991).

Também o aumento da umidade na copa, pode ser um fator preponderante de queda de frutos, visto que a água é um substrato favorável para o desenvolvimento de fungos que se alojam na inserção do fruto (pecíolo) e causam o rompimento desta ligação (Tubelis e Salibe, 1991).

Como se pode perceber, a forma de se irrigar esta planta, sub ou sobre copa, a época em que se irriga (antes da florada, durante ou após a formação inicial do fruto), a quantidade de água que se utiliza para irrigar, a freqüência desta irrigação e a profundidade molhada são detalhes importantes para que a produtividade dos frutos cítricos seja otimizada. A queda de frutos no mês de julho, no hemisfério norte, e no mês de novembro, no hemisfério sul, denominada de "June-drop", está associada com o 
stress hídrico que esta cultura normalmente sofre nesta época de final de primavera (Giorgi et al, 1991; Marsh, 1968).

\subsection{Efeitos da água e do nitrogênio na produção dos citrus}

Malavolta et al. (1984) verificaram que o peso de matéria seca dos frutos, intensificou-se a partir do segundo mês após o florescimento das plantas cítricas. As quantidades médias de nutrientes exportados pelos cultivares, em quilograma por tonelada de frutos frescos, foram: $\mathrm{N}=1,67, \mathrm{P}=0,17, \mathrm{~K}=2,18, \mathrm{Ca}=0,66, \mathrm{Mg}=0,17 \mathrm{e}$ $S=0,42$, que demonstra a importância do nitrogênio na adubação desta cultura.

Trabalhos realizados por Koo e Reese (1977), Koo (1980), Hilgeman (1977) e Bester et al. (1977) mostram que a produtividade do citrus é influenciada de forma distinta quando se compara a aplicação de fertirrigação nitrogenada com a adubação e irrigação convencionais, nas mesmas doses de nitrogênio e água.

As doses anuais de nitrogênio utilizadas em experimentos onde foi combinado a aplicação de nitrogênio com a água de irrigação são de 365, 650 e 935 g/árvore (Koo et al., 1974); 192, 256 e 345 g/árvore nos três primeiros anos e o dobro desta dose nos anos seguintes (Koo, 1980); 50, 100 e 150 g/árvore (Barreda et al., 1984) e 287, 485 e 885 g/árvore (Bielorai et al., 1984).

Para o controle da inrigação em citrus tem-se utilizado tensiômetros e tanque Classe A. Os tensiômetros têm sido instalados à profundidades de 30 a $46 \mathrm{~cm}$ (Koo et 
al., 1974), 45, 75 e $150 \mathrm{~cm}$ (Hilgeman, 1977) e 50 e $100 \mathrm{~cm}$ (Koo, 1980). O tanque Classe A também foi utilizado por Koo (1979 e 1980) e Barreda (1984).

Analisando a produtividade de limões (Citrus limon L.), por um período de quatro anos, em função de três doses de nitrogênio (365, 650 e 935 g/árvore/ano) divididas em três aplicações anuais e dois níveis de irrigação, Koo et al. (1974) provocou aumento na produção de frutos, aumento na ocorrência de frutos verdes e decréscimo no conteúdo de ácido cítrico no suco em função do aumento na dose de nitrogênio. $\mathrm{O}$ aumento da lâmina de irrigação causou redução da acidez, no tamanho de frutos e no número de frutos verdes na colheita, além de reduzir os defeitos de superfície da casca.

Mungomery et al. (1978) observaram que $900 \mathrm{~g}$ de N/árvore por ano aplicados no inverno foi a dose ideal para maximizar a produção de frutos de laranja. Haag et al. (1993) aplicando 1215 g de N/árvore em laranja Pêra, extraíram 462 g de N em 1724 frutos colhidos por árvore e concluíram que esta adubação deve ser feita antes do período de emissão de ramos produtivos.

Malavolta et al. (1984) estudaram o fracionamento de $150 \mathrm{~kg}$ de $\mathrm{N} / \mathrm{ha}$ em uma, duas e quatro vezes por ano, em pomares não irrigados tendo uréia como fonte de nitrogênio. A subdivisão desta dose em duas aplicações maximizou a produção. Tal fato vem confirmar que na ausência de irrigação, a adubaçao nitrogenada deve ser feita em menores número de aplicações. Estas duas épocas de adubação, coincidem com o período de emissão de ramos produtivos e o período de enchimento dos frutos. 
Bielorai et al. (1984) também encontraram uma relação direta entre doses de nitrogênio aplicadas por fertirrigação em intervalos regulares de sete dias, no período de primavera-verão e produção de laranja. Não observaram tendência quadrática dos resultados de produção, apesar de terem sido empregadas altas doses de nitrogênio e lâminas de água.

Plessis e Koen (1984) trabalhando com laranja Valência, observaram que as produções aumentaram de 232 para $314 \mathrm{~kg}$ /árvore entre as doses de 0 a $630 \mathrm{~g}$ N/árvore por ano e que diminuíram para $310 \mathrm{~kg} /$ árvore com a dose de $840 \mathrm{~g}$ N/árvore por ano, mostrando que pode ter sido atingido a dose excessiva de nitrogênio, entre 630 e $840 \mathrm{~g}$ $\mathrm{N} /$ árvore por ano.

Sharples e Hilgeman (1969) trabalhando com laranja valência irrigada, encontraram uma relação direta entre as doses de nitrogênio e a produção de frutos. A produção variou entre 662 para a testemunha até 870 frutos por árvore para uma dose de $3,63 \mathrm{~kg} /$ árvore.

Orphanos e Eliades (1992) trabalhando com três níveis de nitrogênio (112, 219 e $317 \mathrm{~kg} / \mathrm{ha}$ ) relativos a oito anos de experimentação em pomares de laranja valência irrigados encontraram produções de frutos, teor de sólidos solúveis e peso de frutos significativamente menores para o primeiro nível, não verificando diferença entre os seguintes.

Koo (1979) trabalhou durante 9 anos (1970 a 1978) com laranja Valência, na Flórida, em um experimento conduzido com os seguintes tratamentos: (a) Irrigação: I1 - 
sem irrigação suplementar, I2 - irrigando toda vez que a planta consumiu $65 \%$ da água disponível do solo; e I3 - irrigando toda a vez que a planta consumiu $35 \%$ da água disponível do solo. (b) Nitrogênio: Nl - 67,2 kg/ha ( de 1970 a 1972); 89,6 kg/ha (de 1973 a 1976) e 112,0 kg/ha ( de 1977 a 1978), N2 - o dobro de N1 e N3 - o triplo de N1

A irrigação foi controlada a uma profundidade de solo de $152 \mathrm{~cm}$ e a adubação nitrogenada foi realizada em três parcelas por ano. Os resultados desse experimento revelaram os seguintes valores médios: $\mathrm{N} 1$ - 3,29 cx/árvore; N2 - 4,14 cx/árvore e N3 4,08 cx/árvore; I1 - 3,35 cx/árvore; I2 - 3,82 cx/árvore e I3 - 4,33 cx/árvore. Verifica-se que, em média, a produção de frutos aumentou em função do aumento da dose de nitrogênio e da freqüência de irrigação.

Koo (1980) realizou um experimento em que a fertilização com nitrogênio foi feita via água de irrigação e de forma convencional. Pela fertirrigação foram realizadas 3 e 10 aplicações anuais e na forma convencional 3 aplicações. Ocorreram diferenças significativas na relação de brix-acidez, na acidez e na produção de caixas de laranja por árvore. O primeiro fator foi maior com fertirrigação, o segundo e o terceiro com adubação convencional. Não houve diferença de brix, entre tratamentos.

Bester et al. (1977) trabalharam com sistema de irrigação por gotejamento e realizaram fertirrigação com adubo N P K solúvel, em laranja Valência, durante quatro anos. Verificaram que o crescimento de frutos é um bom indicador para freqüência de irrigação. Irrigações com alta freqüência não são necessárias em citrus devendo ser reiniciadas apenas quando os frutos deixam de crescer. A irrigação causa uma aceleração 
no crescimento dos frutos, compensando o stress hídrico a que foi submetido, sendo que o aumento no crescimento depende da quantidade de água aplicada após o stress.

Hilgeman (1977) conduziu experimentos com laranja durante os anos de 1949 a 1969 com quatro tratamentos de irrigação: $\mathrm{Il}=175 \mathrm{~cm} /$ ano distribuídos em 15 aplicações; I2 = $135 \mathrm{~cm} /$ ano distribuídos em 10 aplicações; $\mathrm{I} 3-95 \mathrm{~cm} /$ ano distribuídos em 15 irrigações e I4 = $175 \mathrm{~cm} /$ ano aplicados nos meses de março a julho (correspondendo ao período de final de verão e durante o outono) e no início de setembro e em novembro. O crescimento do tronco, da copa, do sistema radicular foram maiores no tratamento I1. No entanto, o teor de sólido solúveis e a acidez não diferiram entre os tratamentos I1, I2 e I3. A produção de frutos nos tratamentos I1 e I4 foram semelhantes, porém maiores que nos tratamentos $\mathrm{I} 2$ e I3. Isto mostra que o déficit hídrico severo que ocorre no final de agosto e moderado no final de outubro, não provocam redução de produtividade na laranja, no hemisfério norte.

Ainda, trabalhando com deficiência hídrica em diferentes épocas do ano (maio, julho, outubro e agosto), Hilgeman (1977) concluiu que o déficit em maio e julho causou redução em número de frutos por árvore e na razão entre sólidos solúveis e acidez.

Guardiola (1992) afirma que o período de consolidação dos frutinhos na árvore marca a transição da fase de flores (ovário) para frutos jovens. Isto pode ocorrer algumas semanas após a quedas das pétalas e estames. Neste período o ovário apresenta uma grande taxa de crescimento, demandando maiores quantidades de assimilados e água. A ausência de assimilados ou de água pode levar à queda dos frutinhos e portanto à 
redução de produção das árvores. Uma das características deste vegetal é de produzir mais flores do que é capaz de manter fixadas durante o crescimento dos frutos, havendo um tendência a reduzir o número relativos de frutos fixados à medida que mais flores são emitidas.

Sobre a relação entre peso individual de frutos e número de frutos produzidos por árvores, Guardiola (1992) afirma que produzindo menos frutos na árvore estes tendem a ser maiores e mais pesados. $\mathrm{O}$ autor conclui que as melhores maneiras de se manipular estas relações, estão no emprego dos hormônios vegetais, os quais podem ser utilizados para estimular o florescimento, evitar a queda ou promover a maturação dos frutos.

Cohen e Goell (1984) trabalhando com indicadores anatômicos para irrigação de citrus, encontraram relação entre as dimensões dos frutos e a freqüência de irrigação. Os autores observaram que à medida em que há deficiência de água no solo, os frutos dos citrus tendem a reduzir de volume, cedendo água para as funções fisiológicas do vegetal. A direção do fluxo dos assimilados e da água são invertidos quando há disponibilidade de água no solo. Trabalhando com "Marsh seedlens grapefruit" os autores encontraram uma queda acentuada no diâmetro dos frutos quando a lâmina de irrigação foi reduzida pela metade da lâmina projetada durante quatro meses.

Bielorai et al. (1984) estudando o efeito da fertirrigação e três frações de áreas irrigadas, aplicaram 550, 750 e $900 \mathrm{~mm}$ de água em intervalos de 7 dias, durante os meses de abril e meados de novembro. Neste trabalho os autores estudaram o efeito de 
três níveis de nitrogênio $(100,170$ e $310 \mathrm{~kg} / \mathrm{ha})$ e encontraram produções de 111,141 e $155 \mathrm{~kg}$ de frutos/árvore, 518, 782 e 810 frutos por árvore e 199, 185 e 195 g/fruto. A média de produção em 4 anos foi de 157, 174 e $195 \mathrm{~kg}$ de frutos/árvore, para cada nível de $\mathrm{N}$.

A definição da quantidade de frutos de laranja produzidos ocorre no mesmo período de acúmulo de matéria seca nos frutos, sendo portanto necessário que os insumos sejam aplicados preferencialmente neste período (Koo et al., 1974; Koo, 1979, Koo, 1980). No entanto, a aplicação de nitrogênio não deve ser feita somente para maximizar a matéria seca dos frutos, mas também para manter em funcionamento o sistema fisiológico do vegetal, o que justifica a adubação nitrogenada durante os 10 meses iniciais de crescimento dos frutos.

Muitos trabalhos desenvolvidos nos climas áridos têm como propósito principal a redução da queda de frutos, como descreve Hilgeman (1977) e não a maximização de produção de frutos. Isso se dá devido a gravidade da queda de frutos em junho no hemisfério norte, denominado de "June drop". Este fenômeno é causado pela deficiência hídrica que ocorre regularmente neste período do ano (início de verão).

Hilgeman (1977) também observou que ocorreu redução no peso dos frutos entre 14 e $16 \%$ quando submeteu as plantas a déficit hídrico nos meses de maio e junho (período de acúmulo de matéria seca nos frutos) e de $12 \%$ no período de agosto a outubro(período de acúmulo de suco e início de maturação), o que demonstra que o déficit hídrico, no solo, afeta o peso dos frutos tanto se ocorrer na fase de frutificação 
quanto na fase de enchimento e maturação dos mesmo. Esta observação vem confirmar a necessidade de irrigação para todo o ciclo de produção desta cultura.

Os frutos cítricos utilizados para consumo in natura no Brasil são classificados, em função do tamanho, em caixas de $27,5 \mathrm{~kg}$ da seguinte forma: "A" - menos de 12 dúzias/caixa, "B" - entre 12 e 16 dúzias/caixa e "C" - mais de 16 dúzias/caixa. O valor econômico dos frutos diminui dos tipos "A" para "C", conforme Gazzola et al. (1991).

\subsection{Função de resposta das culturas}

Função de resposta, ou de produção das culturas é uma relação física entre as quantidades de certo conjunto de insumos e as quantidades físicas máximas que podem ser obtidas do produto, para dada tecnologia conhecida. Assim, ao se supor que a função de resposta representa o máximo que se pode obter com o uso de cada combinação de insumos, está se definindo uma relação funcional entre os insumos e o produto (Noronha, 1984). Pode-se expressar matematicamente a função de resposta da seguinte forma (Frizzone, 1986):

$$
\mathbf{Q}=\mathbf{Q}\left(\mathrm{U}_{1}, \mathrm{U}_{2}, \ldots, \mathrm{U}_{\mathrm{z}}\right)
$$

em que, $\mathbf{Q}$ é a quantidade produzida e $\mathbf{U}_{\mathbf{1}}, \mathbf{U}_{2}, \ldots, \mathbf{U}_{\mathbf{z}}$ são insumos que participam desse processo e se transformam em $\mathbf{Q}$. Essa representação matemática significa que $\mathbf{Q}$ é uma função de $\mathbf{U}_{1}, \mathbf{U}_{2}, \ldots, \mathbf{U}_{\mathbf{z}}$. 
Uma pressuposição importante, embora não esteja explicitada, é que a função de resposta da cultura, representada por uma única equação matemática, é contínua e possui derivadas de primeira e segunda ordens conhecidas (Palacios-Velez, 1981). Tais funções de resposta são relações empíricas, geralmente obtidas mediante análise de regressão entre uma variável dependente e uma ou mais variáveis independentes, segundo um determinado modelo. A escolha do modelo deve ser orientada pela sua capacidade de representar os dados reais, pela facilidade de uso de computadores para o ajustamento do modelo, pela análise de variância, para testar a estabilidade dos parâmetros e a sua interpretação (Colwell, 1984). O importante é que todos os modelos são essencialmente empíricos e que a escolha de um deles deverá basear-se na sua capacidade de representar os dados experimentais reais, pelo menos, dentro das faixas de maior interesse para o pesquisador.

A produção das culturas em relação à quantidade de água aplicada depende de muitos fatores, alguns dos quais são: quantidade e freqüência de irrigação (Frizzone et al., 1985), método de aplicação de água, condições estacionais de crescimento, fertilidade do solo, clima e seus efeitos interativos sobre o crescimento das culturas (Colwell, 1984). Consequentemente, no estudo dessas funções sempre existe uma variação não explicada, chamada de variância residual. Além disso, os valores de muitas variáveis somente estão disponíveis após terem afetado a produtividade das culturas. Assim, é muito difícil fazer previsão de produtividade, sendo possível apenas obter valores aproximados. 
Muitas funções de resposta obtidas experimentalmente são relações lineares. Uma razão provável é que a produção relaciona-se linearmente com a evapotranspiração (Howel e Hiler, 1975 e Doorenbos e Kassan, 1979). Outra é que, para muitas aplicações simplificadas, uma aproximação grosseira é suficiente. Ainda, na definição do experimento, pode ocorrer que os ratamentos não foram selecionados de forma a contemplar um domínio tão amplo quanto necessário para permitir a obtenção de funções não lineares.

Na maioria dos problemas práticos há necessidade do emprego de funções não lineares que apresentam pontos de máximo ou mínimo, para que, numa análise econômica, obtenha-se o valor ótimo da variável independente (Haxem e Heady, 1978). A função de resposta polinomial quadrática tem sido a forma mais utilizada pelos pesquisadores. A formulação geral de um polinômio pode ser expressa por:

$$
Q=\sum_{p=0}^{P} \mathbf{r}_{p} U^{p}
$$

sendo $\mathbf{r}_{\mathbf{p}}$ os parâmetros da função, $\mathbf{p}$ o grau do polinômio. Para $\mathbf{p}=1$ a função é linear, e $\mathbf{p}=2$ é quadrática e $\mathbf{U}^{\mathrm{p}}=$ variável independente.

Existem diferentes aplicações das funções de resposta como, por exemplo, determinar a relação entre a quantidade de água aplicada e os benefícios econômicos resultantes, fazer previsão de safra e estudar os efeitos ambientais sobre a produção das culturas (Haxem e Heady, 1978; Eckert et al., 1978; Hargreaves e Samani, 1984; Frizzone, 1986; English, 1990 e Paz, 1995). 
Na Figura 1 ilustra-se uma relação geral entre quantidade de água aplicada e produtividade da cultura. A linha pontilhada representa a relação entre evapotranspiração e produtividade e a linha contínua a relação entre quantidade de água aplicada e produtividade.

Embora a Figura 1 represente uma única relação entre produtividade e evapotranspiração, deve-se considerar que o método e a freqüência de irrigação podem afetar significativamente a produtividade, independente da quantidade de água usada pela planta (Hargreaves e Samani, 1984). A curva produtividade-água aplicada divide-se em duas zonas de acordo com Solomon (1985): a zona I caracterizada como zona de déficit de água e a II como de excesso. Quando uma pequena quantidade de água é aplicada, ela pode ser totalmente usada pela cultura, mas as curvas de evapotranspiração e água aplicada, apesar de próximas, não são coincidentes (Cuencas,1989 e English, 1990).

A relação produção-água aplicada pode ser considerada linear até, aproximadamente, $50 \%$ da quantidade de água que resulta na máxima produção (Hargreaves e Samani, 1984). Para maiores quantidades de água, a função começa a declinar, refletindo as perdas de água que ocorrem próximo da condição de irrigação sem déficit (Hart et al., 1979 e English, 1990). Se o aumento da quantidade de água aplicada está associado com alta freqüência de irrigação, a perda por evaporação pode se intensificar, especialmente em irrigação por aspersão, com relativamente pequeno aumento na produção (Hanks, 1974 e Keller e Bliesner, 1990). 


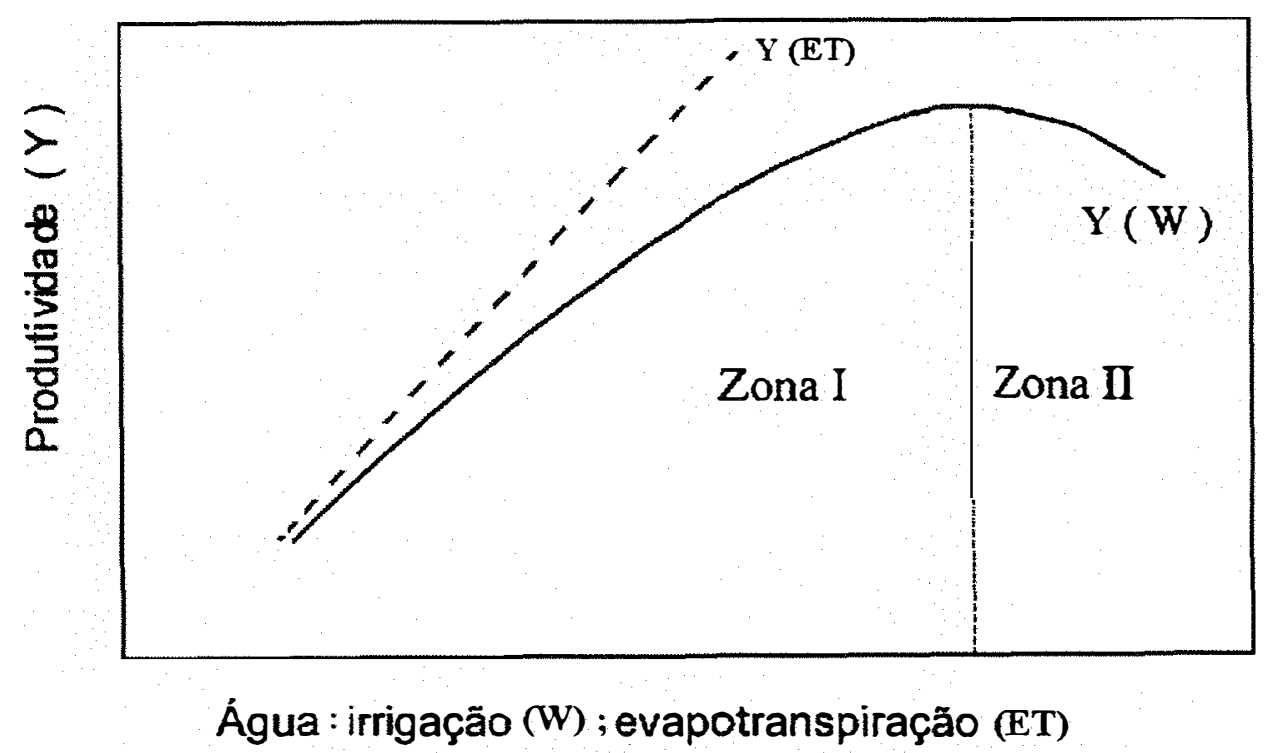

Figura 1. Representação esquemática de uma função de produção tendo a água como fator variável

A eficiência da irrigação tende ao máximo quando a quantidade de água aplicada se aproxima da irrigação sem déficit. Esse declínio na eficiência relaciona-se com a uniformidade de distribuição de água e com as características da cultura e do solo (Solomon, 1985; Bosch et al., 1987; English e Nakamura, 1989 e Coelho, 1990). Na zona I, a curva que representa a quantidade de água aplicada aproxima-se da reta de evapotranspiração para baixos níveis de aplicação de água, mas se afasta progressivamente da mesma para maiores níveis (Solomon, 1985).

A forma da curva na zona II depende de outros fatores. Após o ponto de máxima produção, a curva começa a declinar como conseqüência da redução da aeração do solo devido ao excesso de água, lixiviação de nutrientes e doenças associadas a solo úmido, 
conforme salientam Stegman et al. (1980). Uma vez que os fatores que afetam a produção na zona II são totalmente diferentes daqueles da zona I, uma formulação matemática diferente seria necessária para a zona II (Solomon, 1985). A natureza dessa relação deveria ser uma função complexa do tempo de duração do excesso de água, da temperatura durante o período de excesso, do estádio de desenvolvimento da cultura que foi submetido ao excesso de água e do tipo de solo, entre outros fatores.

Hart et al. (1979) sugeriram que, quando a quantidade de água aplicada excede a necessidade da cultura, o lucro diminui linearmente com o aumento da quantidade de água. Com base nessas considerações, Solomon (1985) sugeriu que na zona II a produção possa ser razoavelmente estimada por uma função que diminui linearmente com o excesso de água.

\subsection{Funções de custo e receita}

Uma vez que a receita bruta é igual a produção da cultura multiplicada por uma constante (o preço do produto), as funções de resposta e receita bruta têm a mesma forma geral. A função curvilínea mostrada na Figura 2 (a) representa uma curva de receita bruta. Existe uma quantidade de água que maximiza a produção e, portanto, a receita bruta, superior àquela que maximiza a receita líquida [Figura 2 (c)], conforme relatam Hart et al. (1979) e Frizzone (1993). 


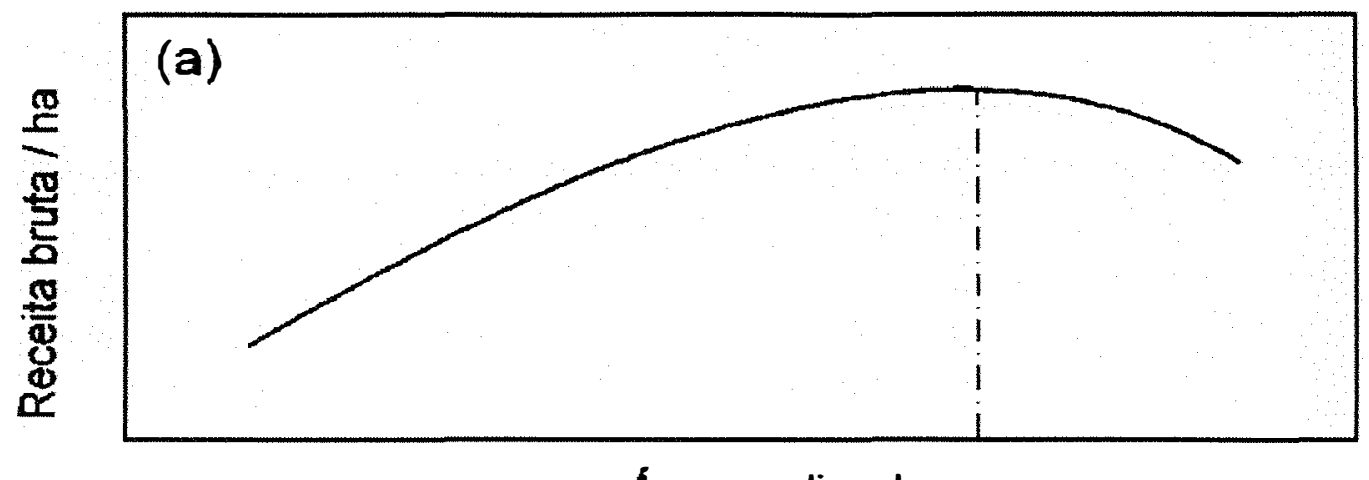

Água aplicada
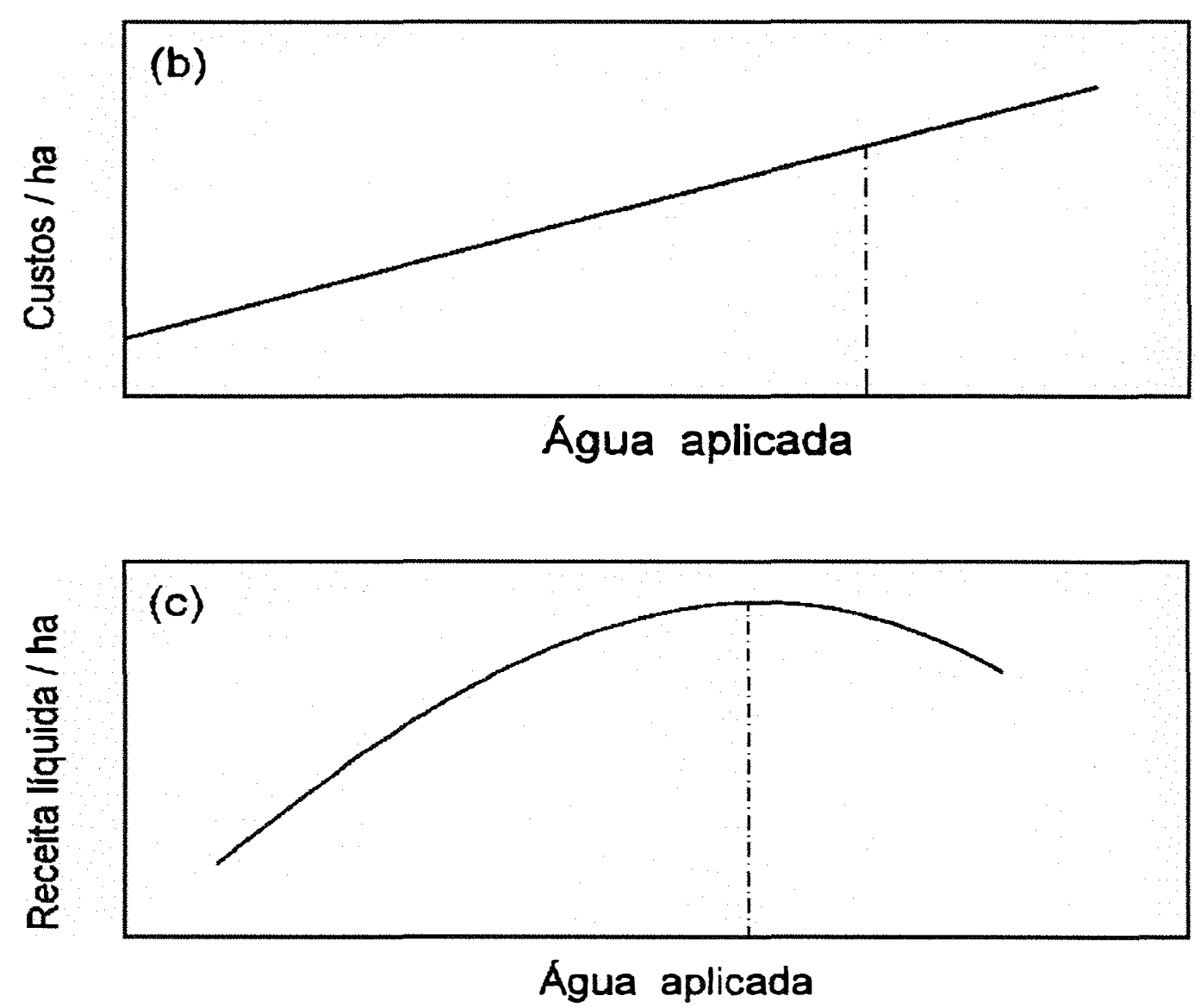

Figura 2. Representação esquemática de funções de (a) receita bruta, (b) custo e (c) receita líquida. 
A linha reta representada na Figura 2 (b) corresponde a uma função de custo, relacionada aos custos totais de aplicação de água. Tal função tem três características (English, 1990). A primeira é o intercepto com a ordenada, o qual está associado aos custos fixos anuais do equipamento de irrigação, e das operações para o preparo do solo e com os custos variáveis de produção da cultura, independentes da irrigação (sementes, fertilizantes, defensivos, cultivo e colheita).

A segunda é a declividade, representando os custos marginais de produção, nos quais incluem os custos variáveis da irrigação (custos de bombeamento, de mão-de-obra e de manutenção).

A terceira característica é o limite superior que está relacionado à capacidade do sistema. Embora a função de custo esteja representada por uma reta, no caso geral ela pode ser curvilínea. A receita líquida por unidade de área, considerando-se a unidade técnica, é definida pela diferença entre a receita bruta proporcionada pela cultura e os custos de produção (English, 1990). 


\section{MATERIAL E MÉTODOS}

\subsection{Localização e caracterização da área}

O experimento foi conduzido no período de junho de 1995 a julho de 1996 no campo experimental do Centro de Irrigação do Departamento de Agronomia da Universidade Estadual de Maringá, situado na cidade de Maringá, Estado do Paraná, situada a $23^{0} 25^{\prime}$ de latitude sul, $51^{0} 57^{\prime}$ de longitude oeste e 542 metros de altitude.

O solo do local é caracterizado como Latossolo Roxo, com topografia suave ondulada e declividade média de $4 \%$. Os resultados das análises química e granulométrica e a densidade global do solo estão apresentados na Tabela 1. A curva de retenção de água no solo é representada na Figura 3. O clima, pela classificação de Köeppen, é caracterizado como "Cfa", sub tropical úmido, mesotérmico, com verão quente e geadas menos freqüentes, com tendências a concentrar as chuvas no período de verão, mas sem estação seca definida (IAPAR, 1987).

Os valores médios mensais de temperatura, precipitação pluvial e evaporação no tanque classe A, para o período compreendido entre os anos de 1980 a 1995, encontram- 
se na Figura 4. Estes valores para o período do experimento (junho de 1995 a julho de 1996) estão apresentados na Figura 5.

Tabela 1. Análises química e granulométrica do solo

\begin{tabular}{|c|c|c|c|c|c|c|c|}
\hline \multicolumn{8}{|c|}{ Análise química } \\
\hline \multirow{2}{*}{$\begin{array}{c}\mathrm{pH} \\
\text { em } \mathrm{CaCl}_{2}\end{array}$} & \multicolumn{5}{|c|}{$\mathrm{cmol}_{\mathrm{c}} / \mathrm{dm}^{3}$} & \multirow{2}{*}{$\begin{array}{c}\mathrm{mg} / \mathrm{dm}^{3} \\
\mathrm{P}\end{array}$} & \multirow{2}{*}{$\frac{\mathrm{g} / \mathrm{dm}^{3}}{\mathrm{C}}$} \\
\hline & $\mathrm{Al}^{++1+}$ & $\mathrm{H}^{+}+\mathrm{Al}^{++}$ & $\mathrm{Ca}^{++}+\mathrm{Mg}^{+}$ & $\mathrm{Ca}^{++}$ & $\mathrm{K}^{+}$ & & \\
\hline 5,12 & 0,00 & 3,88 & 7,43 & 5,98 & 0,43 & 1,50 & 13,62 \\
\hline \multicolumn{8}{|c|}{ Análise granulométrica e densidade global } \\
\hline \multicolumn{2}{|c|}{ Camada $(\mathrm{cm})$} & \multicolumn{2}{|c|}{ Argila (\%) } & Silte (\%) & Areia (\%) & \multicolumn{2}{|c|}{ Densidade global $\left(\mathrm{g} / \mathrm{cm}^{3}\right)$} \\
\hline \multicolumn{2}{|c|}{$0-15$} & \multicolumn{2}{|r|}{87} & 9 & 4 & \multicolumn{2}{|c|}{1,23} \\
\hline \multicolumn{2}{|c|}{$15-30$} & \multicolumn{2}{|r|}{85} & 11 & 4 & \multicolumn{2}{|c|}{1,28} \\
\hline \multicolumn{2}{|c|}{$30-45$} & \multicolumn{2}{|r|}{78} & 16 & 6 & \multicolumn{2}{|c|}{1,34} \\
\hline
\end{tabular}

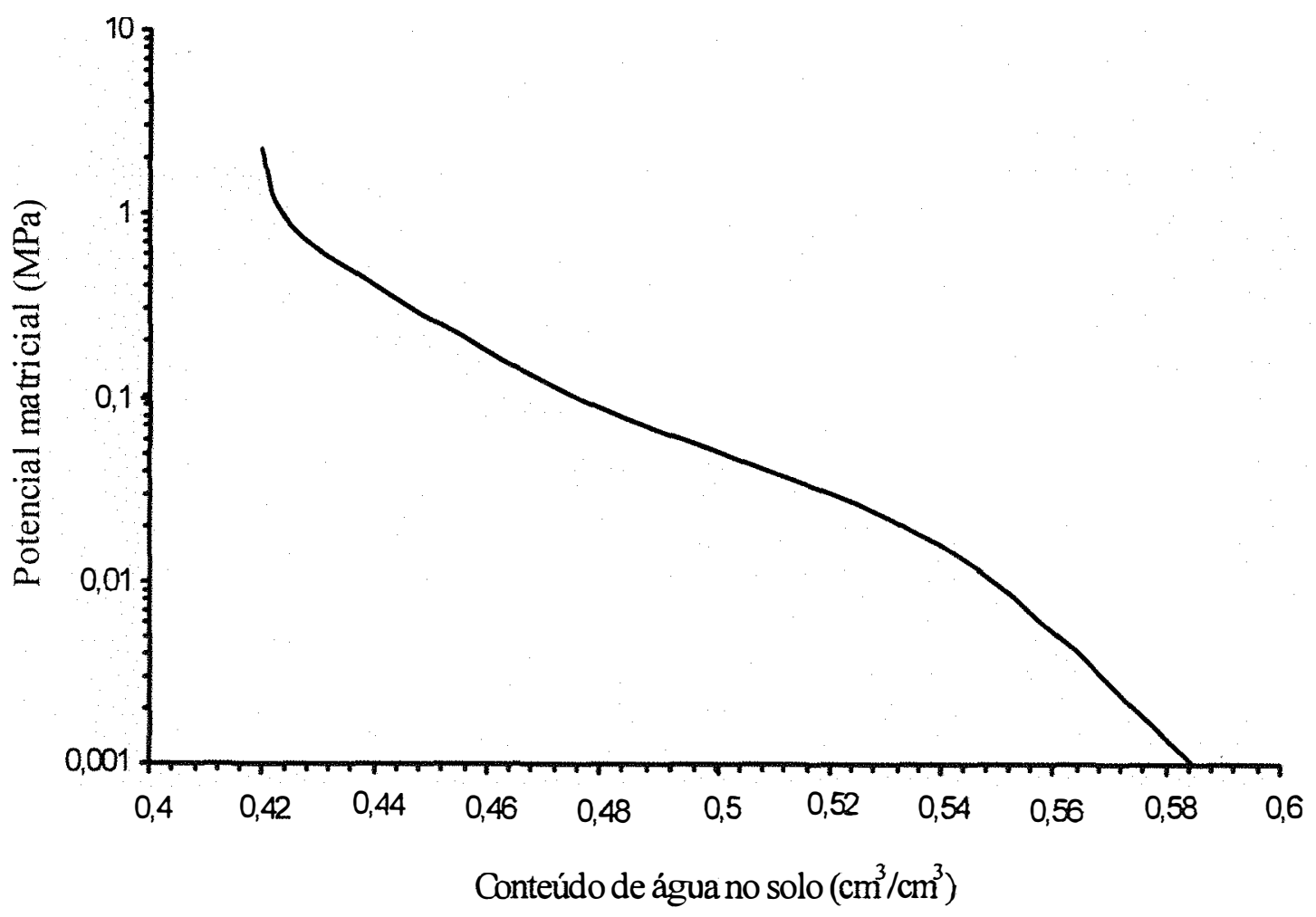

Figura 3. Curva de retenção de água no solo 


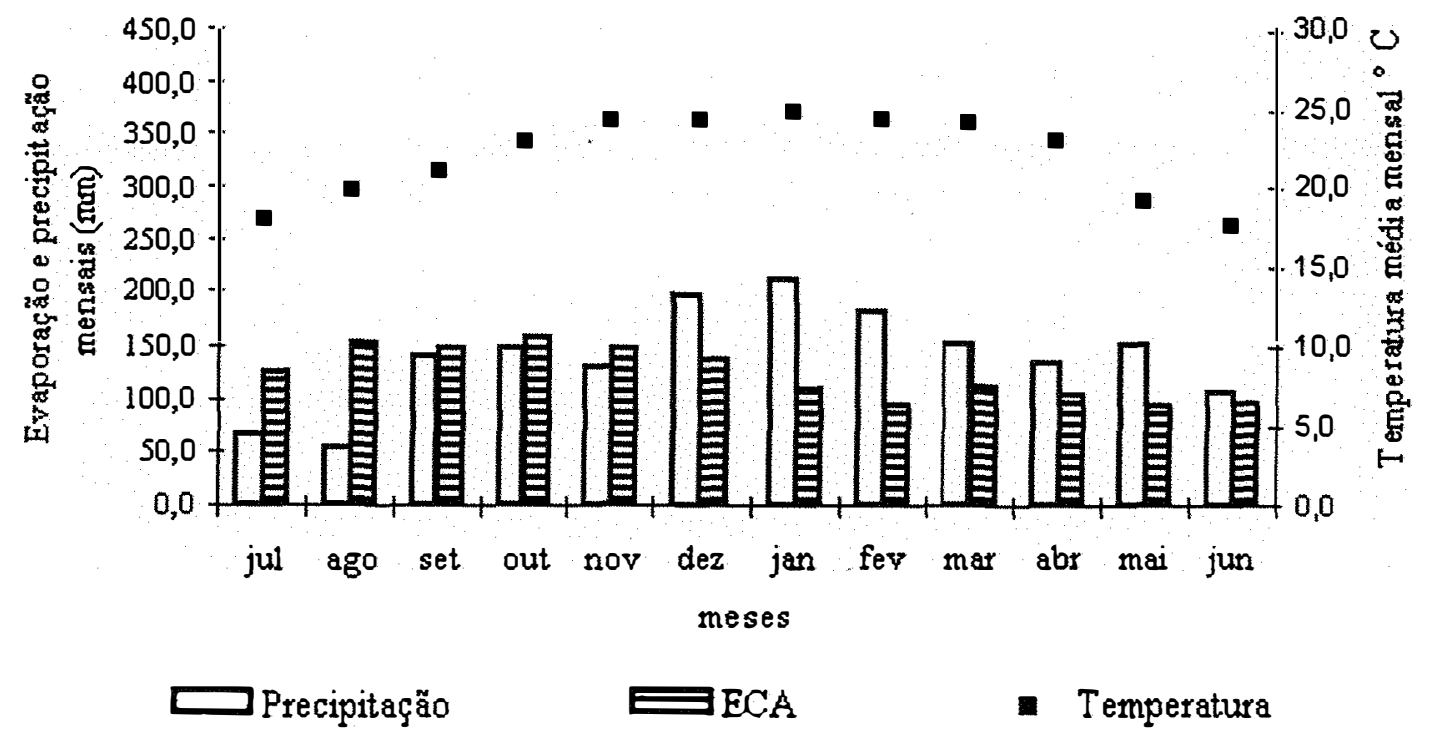

Figura 4. Médias mensais da evaporação do tanque classe A, precipitação e temperatura média para os anos de 1980 a 1995.

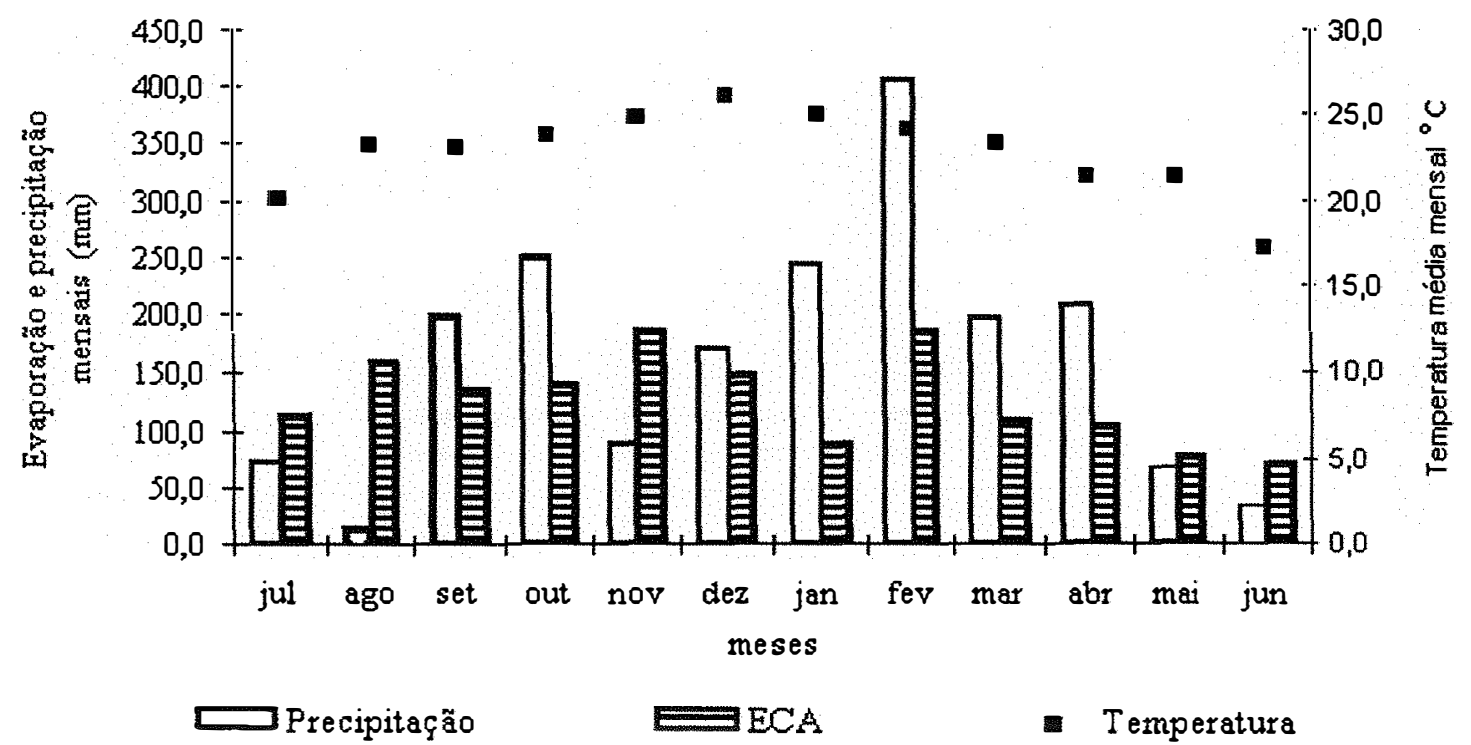

Figura 5. Médias mensais da evaporação do tanque classe A, precipitação e temperatura média no período do experimento (julho de 1995 a junho de 1996). 


\subsection{Práticas culturais}

Para a condução do experimento foram selecionadas 19 plantas, consecutivas, de laranja Pêra (Citrus sinensis Osbeck cv. Pêra), enxertadas sobre limão cravo (Citrus limonia Osbeck cv. Cravo), em cada uma das nove linhas de plantio, no pomar do Centro Técnico de Irrigação da Universidade Estadual de Maringá. O pomar possuía quatro anos, quando foi iniciado o experimento e 5 anos quando foi feita a colheita dos frutos. As linhas de plantas deste pomar estão, com espaçamento de sete metros entre linhas por quatro metros entre plantas.

A adubação da cultura constituiu de calagem de pré-plantio e adubação de covas. Foram incorporados 1,3 t/ha de calcário dolomítico (PRNT de $80 \%$ ) e nas covas foram aplicados $5 \mathrm{~kg}$ de esterco de curral, $200 \mathrm{~g}$ de superfosfato simples, $250 \mathrm{~g}$ de calcário dolomítico, 1,25 g de $\mathrm{Zn}$ e 1,0 g de boro. A partir do segundo ano, a adubação foi repetida anualmente até o quarto ano, aplicando os adubos minerais na projeção da copa das árvores, em doses crescentes de 100 a 300 g de nitrogênio, de 100 a 150 g de $\mathrm{P}_{2} \mathrm{O}_{5}$ e de 120 a 250 g de $\mathrm{K}_{2} \mathrm{O}$ por árvore, conforme recomenda Malavolta e Violante Neto (1988).

A evapotranspiração da cultura (Etc) foi estimada a partir da correção da evapotranspiração de referência (Eto) e esta a partir dos dados de evaporação do tanque classe A (ECA) da Estação Climatologica principal de Maringá, segundo Doorenbos e Pruitt (1977). 
O controle fitossanitário não foi necessário durante a fase de formação da cultura, mas foi conduzido durante o experimento, com aplicações periódicas de 10 litros por árvore de solução de Abamectin $(0,3 \%)$ a cada 40 dias. Estas aplicações foram recomendadas por ter sido detectado a presença do ácaro da leprose (Brevipalpus phoenicis) durante o período de colheita dos frutos produzidos no ano anterior à instalação do experimento. Não foi observada a presença de outras pragas ou doenças.

Para que o ensaio fosse instalado, todos os frutos das árvores do pomar foram derriçados no mês de maio de 1995, quando foi feita a adubação para o primeiro ano de produção econômica, constituída de $300 \mathrm{~g}$ de $\mathrm{P}_{2} \mathrm{O}_{5}$ e $400 \mathrm{~g}$ de $\mathrm{K}_{2} \mathrm{O}$ (Malavolta e Violante Neto, 1988), não tendo sido aplicado o nitrogênio.

\subsection{Delineamento experimental}

Utilizou-se um delineamento experimental inteiramente casualizado, com quarenta e dois tratamentos, compostos da combinação de sete niveis de irrigação e seis níveis de nitrogênio. Para cada nível de irrigação foi casualizada uma linha de árvores, irrigada pela mesma linha de microaspersores e dividida em seis sub-parcelas, onde foram casualizadas as doses de nitrogênio.

Fizeram parte de cada sub-parcela experimental, duas árvores consecutivas, e entre as sub parcelas havia uma árvore como bordadura. Estas receberam o mesmo tratamento de água da parcela e não receberam aplicações de nitrogênio. Também foram 
utilizadas duas linhas de árvores irrigadas como bordaduras do experimento, isolando a área experimental do restante do pomar, mas não foram utilizadas bordaduras entre linhas de aplicação de água (Figura 6).

\subsection{Tratamentos}

Os níveis de irrigação foram casualizados em sete linhas de emissores, ao longo da linha de derivação, sendo respectivamente: $\mathrm{W}_{0}=0 ; \mathrm{W}_{1}=30 ; \mathrm{W}_{2}=60 ; \mathrm{W}_{3}=90 ; \mathrm{W}_{4}$ $=120 ; \mathrm{W}_{5}=150$ e $\mathrm{W}_{6}=180$ litros por árvore e por aplicação. Irrigou-se toda vez que o valor acumulado da evapotranspiração da cultura atingia $7,3 \mathrm{~mm}$. Durante o experimento foram efetuadas 48 irrigações, tendo sido aplicados por tratamento $0 ; 1440,2880,4320$, 5760, 7200 e 8640 litros de água por árvore.

Nos tratamentos de nitrogênio, seis doses foram casualizadas ao longo de cada linha de emissores, respectivamente: $\mathrm{N}_{0}=0 ; \mathrm{N}_{1}=2,5 ; \mathrm{N}_{2}=5,0 ; \mathrm{N}_{3}=7,5 ; \mathrm{N}_{4}=10,0$ e $\mathrm{N}_{5}$ $=12,5$ gramas de nitrogênio por árvore aplicadas semanalmente e totalizando 0;107,5; 215; 322,5; 430 e 537,5 g/árvore em 43 aplicações durante o experimento.

\subsection{Adubação nitrogenada}

Utilizou-se como fonte de nitrogênio a Uréia ( $40 \%$ de N). A dose de nitrogênio de 7,5 g/árvore por aplicação semanal foi baseada na recomendação de Vitti (1992) e 


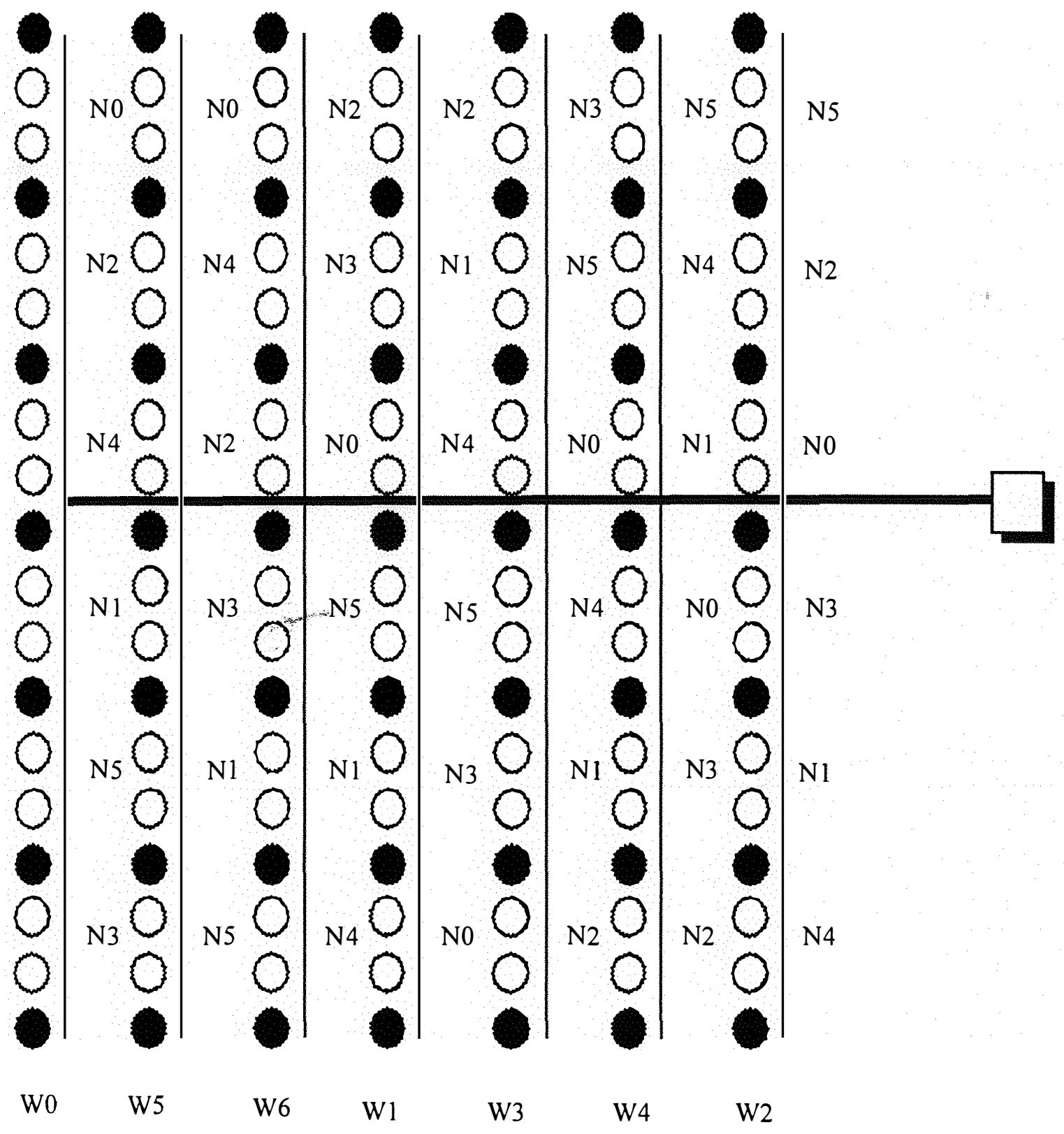

Árvores que delimitam os tratamentos

Árvores tratamento

Wi Níveis de água $(\mathrm{i}=0,1,2,3,4,5$ e 6)

$\mathrm{Nj} \quad$ Níveis de nitrogênio $(\mathrm{j}=0,1,2,3,4$ e 5)

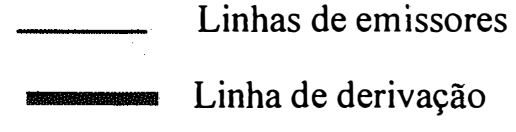

Cabeçal de controle

Figura 6. Diagrama esquemático da área experimental 
Malavolta e Violante Neto (1988) para adubação nitrogenada da cultura da laranja em fase de produção,considerando-se 43 semanas o período de aplicação de nitrogênio durante o ciclo anual da cultura (julho de 1995 a abril de 1996), excetuando-se a fase de maturação dos frutos (maio/96 a julho/96).

Antes de cada adubação diluíam-se $1000 \mathrm{~g}$ de nitrogênio (2500 g de uréia) em água, na proporção de $10 \%$ em peso, sendo aplicados $125,100,75,50$ e $25 \mathrm{ml}$ de solução, respectivamente nos tratamentos $\mathrm{N}_{5}, \mathrm{~N}_{4}, \mathrm{~N}_{3}, \mathrm{~N}_{2}, \mathrm{~N}_{1}$. Esses valores correspondem a 537,$5 ; 430,0 ; 322,5 ; 215,0$ e 107,5 gramas de $\mathrm{N}$ por planta.

A aplicação de nitrogênio, subdividindo a dose anual recomendada por Malavolta e Violante Neto (1988) em quarenta e três aplicações, teve como propósito, aumentar a eficiência de aproveitamento do nirogênio pelas plantas, reduzindo as perdas por lixiviação.

3.6. Controle da irrigação

Utilizou-se um sistema de microaspersão, com um emissor por árvore, com vazão de $30,5 \mathrm{l} / \mathrm{h}$ à pressão de serviço de 10 m.c.a. e raio de alcance de $1,76 \mathrm{~m}$. No inicio de cada linha lateral foi colocado um registro de gaveta para controlar o volume de água aplicado por tratamento.

Os volumes de água de irrigação aplicados foram calculados em função da evapotranspiração da cultura (Etc), estimada com base na evaporação do tanque classe $\mathrm{A}$ 
(ECA), conforme parametrizado por Doorenbos e Pruitt (1977) e modificado por Vermeiren e Joblin (1988) para irigação localizada.

$$
\mathbf{E t c}=(\mathrm{ECA} \cdot \mathrm{Kp} \cdot \mathrm{Kc}) \cdot \mathrm{Kr}
$$

sendo Kp o coeficiente de tanque $(0,75)$, Kc o coeficiente de cultura $(0,75)$ e $\mathbf{K r}$ a correção da evapotrasnpiração para área parcialmente coberta com vegetação (equação $4)$.

$$
\mathbf{K r}=\mathbf{G C}+\frac{(1-\mathbf{G C})}{2}
$$

sendo:

GC - fração da área ocupada por uma árvore em função da área média da projeção da $\operatorname{copa}\left(12,57 \mathrm{~m}^{2} / 28 \mathrm{~m}^{2}=0,45\right)$

O volume de água por planta foi estimado pela relação:

$$
W_{i}=A \cdot E t c \cdot \frac{\alpha}{100}
$$

sendo, A - área definida pelo espaçamento da cultura $\left(28 \mathrm{~m}^{2}\right)$, Etc - evapotranspiração da cultura para controle da irrigação $(7,3 \mathrm{~mm})$ e $\alpha$ - porcentagem da evapotranspiração da cultura estabelecida para cada tratamento $(15,29,44,59,74$ e $88 \%)$

- Na Tabela 2, encontram-se os valores mensais de evaporação do tanque classe A (ECA), as precipitações mensais ocorridas no experimento (PREC), o número de irrigações mensais (Ni) e os respectivos intervalos entre irrigações (I). Também 


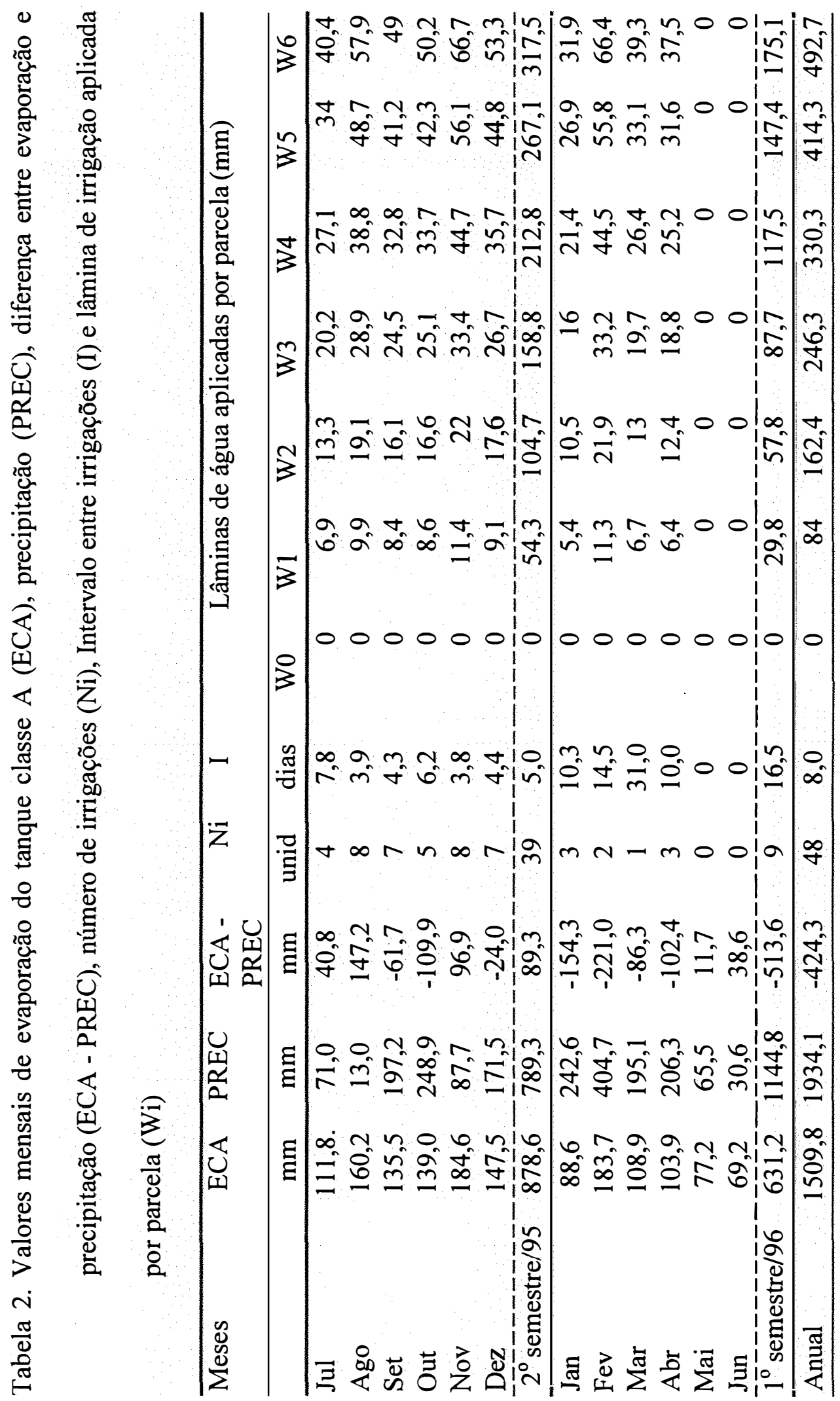


encontram-se nesta tabela as lâminas mensais de irrigação em cada parcela $\left(W_{0}, W_{1}, W_{2}\right.$, $\mathrm{W}_{3}, \mathrm{~W}_{4}, \mathrm{~W}_{5}$ e $\mathrm{W}_{6}$ ) e os respectivos valores semestrais e anuais.

A apresentação dos valores semestrais (julho a dezembro de 1995 e janeiro a julho de 1996), teve o propósito de evidenciar a distribuição mensal de chuvas ocorridas e sua consequente influência na quantidade total de água, bem como no número e intervalo entre irrigações em cada período.

Pode-se observar que no segundo semestre de 1995 a precipitação mensal foi maior que a evaporação do tanque classe A somente nos meses de setembro e dezembro. Na figura 7 observa-se que no mês de setembro, as chuvas iniciaram-se a partir do dia 20, quando já haviam sido realizadas 19 irrigações, ou seja $40 \%$ do total de água foi aplicada neste período ( durante o florescimento e frutificação).

No primeiro semestre de 1996 foram realizadas 39 irrigações, com intervalo médio de 5 dias, correspondendo a $81 \%$ de todas as irrigações realizadas.

Durante o segundo semestre de 1995, a precipitação superou a evaporação do tanque classe A em 513,6 mm. Avaliando este semestre, observa-se que a evaporação do tanque classe A foi maior que a precipitação somente nos meses de maio e junho, quando as irrigações haviam sido suspensas. Neste semestre foram efetuadas 9 irrigações durante os meses de janeiro a abril com uma frequência média de 16,5 dias (19\% de todas as irrigações a que foi submetido o experimento). 
Valores diários da precipitação e da evapotranspiração acumulada da cultura entre irrigações e as datas em que ocorreram as irrigações, podem ser observados nas Figuras 7 e 8 .

\subsection{Parâmetros avaliados}

A produção foi estimada a partir da pesagem dos frutos de cada árvore e transformada em caixas de frutos, dividindo-se o valor do peso total destes por $40,8 \mathrm{~kg}$ (peso de uma caixa de frutos).

O volume de suco, tanto por fruto como por árvore, foi estimado a partir do suco extraído de dez frutos, coletados ao acaso dentre os colhidos em cada árvore, repetindose esta operação três vezes, tomando-se os valores médios de cada amostragem. $\mathrm{O}$ valor médio de suco por fruto, foi multiplicado pelo número de frutos para se estimar o volume de suco por árvore.

A porcentagem de sólidos solúveis, foi estimada com o uso de um polarímetro de BRIX, à temperatura constante de $20^{\circ} \mathrm{C}$. Para tanto, foi amostrado suco homogeneizado de dez frutos, de cada tratamento, repetindo-se esta operação três vezes, tomando-se os valores médios das leituras. O suco utilizado para esta leitura foi congelado imediatamente após a extração e mantido a $-5^{\circ} \mathrm{C}$ até a leitura. 


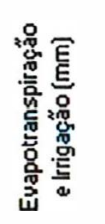

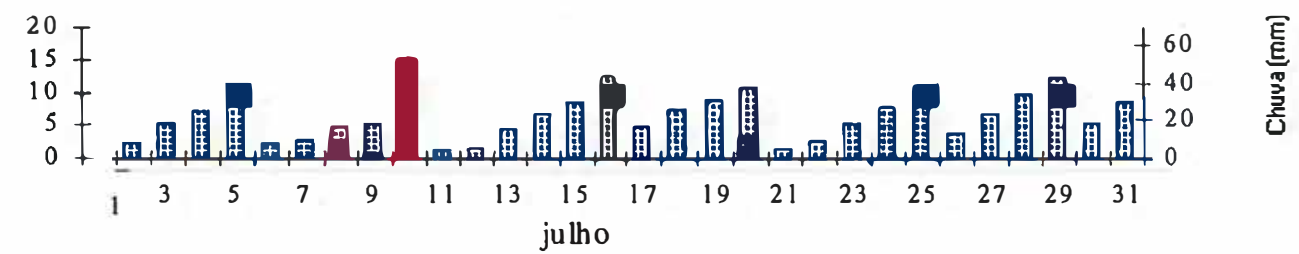
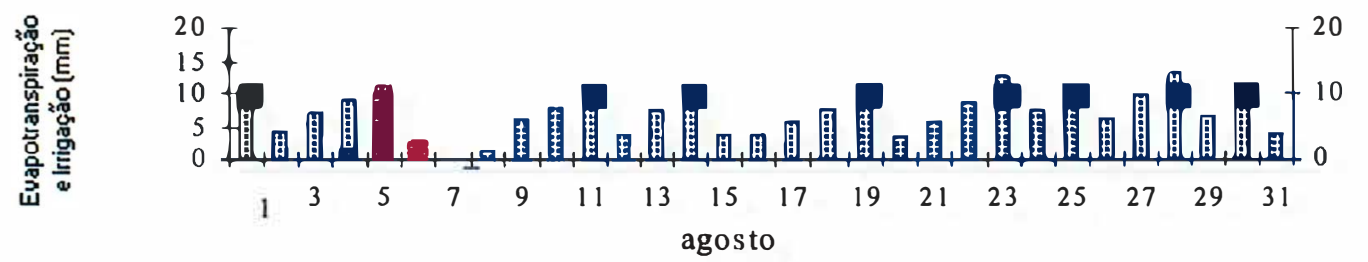

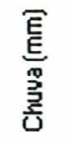
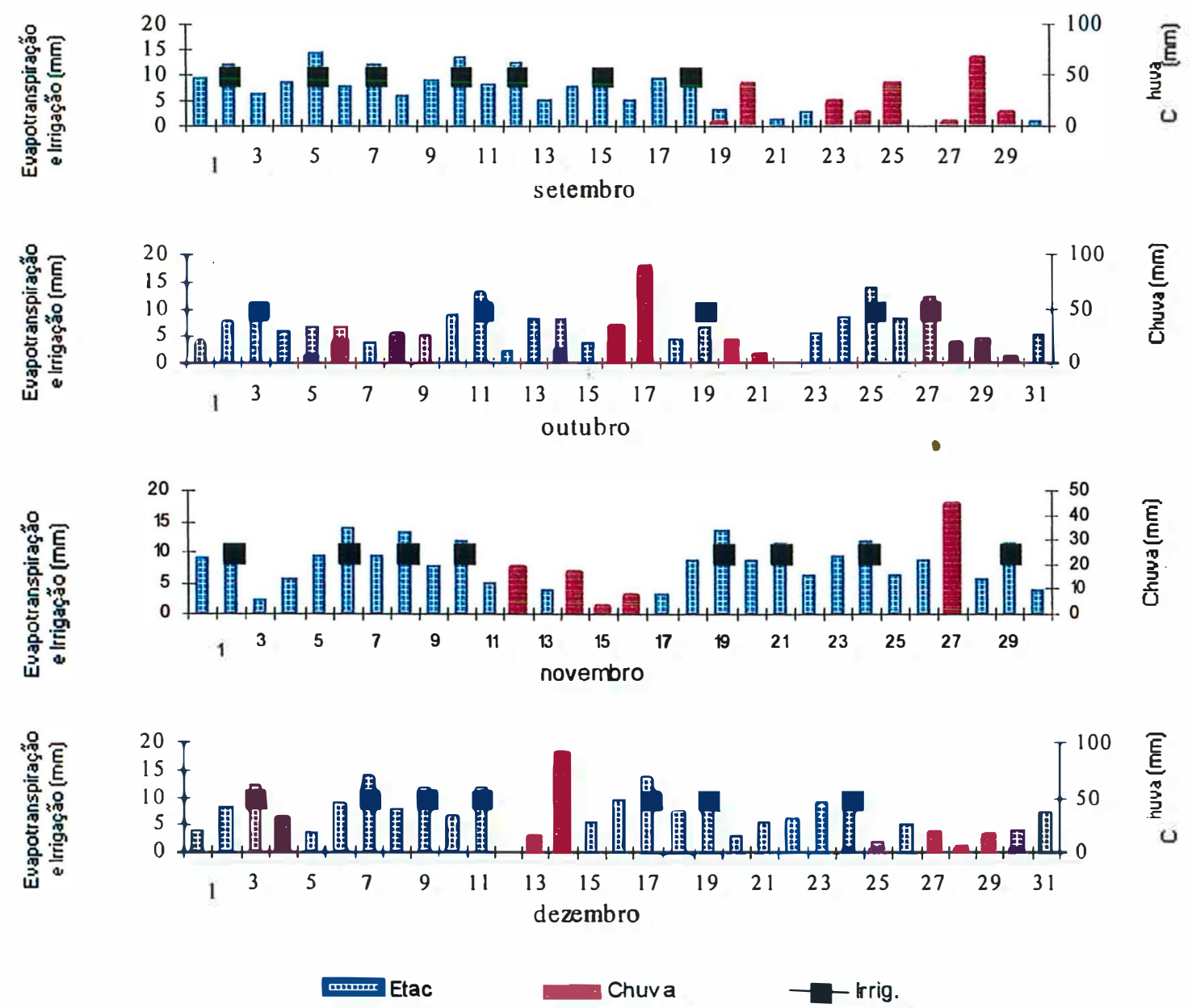

Figura 7. Evapotranspiração da cultura acumulada entre irrigações, precipitação pluvial e irrigações no período de julho a dezembro de 1995. 

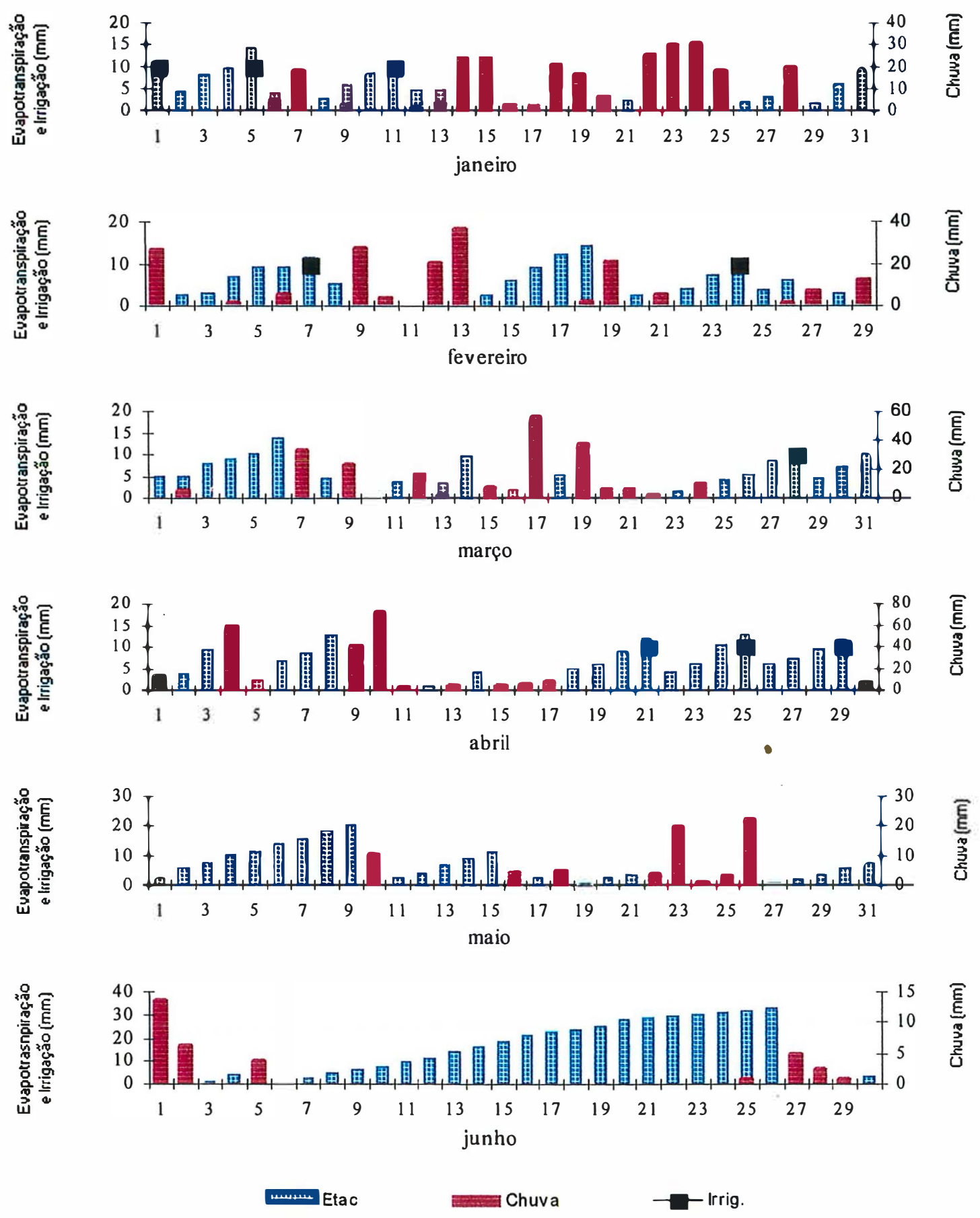

Figura 8. Evapotranspiração da cultura acumulada entre irrigações, precipitação pluvial e irrigações no período de janeiro a junho de 1996. 
A quantidade de sólidos solúveis por árvore, foi estimada pelo produto entre o volume de suco estimado para cada tratamento e o valor médio de sólidos solúveis estimado em cada tratamento.

O número de frutos por árvore foi obtido no final da emissão de botões florais (no final de agosto de 1995), ao fim da florada (no final de setembro de 1995) e na colheita (em julho de 1996), para que se pudesse detectar se a produtividade era função dos frutos produzidos ou da queda destes frutos.

A colheita foi iniciada quando pelo menos uma parcela apresentou Brix médio de 10 frutos superior a $10 \%$. Estas leituras foram feitas com um polarímetro portátil sem controle de temperatura.

\subsection{Funções de resposta da laranjeira}

Estudou-se a produtividade de laranja pêra (caixas de frutos por árvore) em função da água e do nitrogênio. O modelo utilizado foi um polinômio do segundo grau, avaliando os efeitos conjuntos destes fatores [equação (6)].

$$
Y(W, N)=b_{0}+b_{1} N+b_{11} N^{2}+b_{2} W+b_{22} W^{2}+b_{12} N W
$$

sendo :

$\mathbf{Y}(\mathbf{W}, \mathbf{N})$ - produtividade de laranja, em função do volume de água e da dose de nitrogênio, caixas de frutos/árvore;

N - nível de nitrogênio, g/árvore; 
W - nível de irrigação, l/árvore; e

$\mathbf{b}_{0}, \mathbf{b}_{1}, \mathbf{b}_{2}, \mathbf{b}_{11}, \mathbf{b}_{22}$ e $\mathbf{b}_{12}$ - parâmetros da função.

Considerando-se não haver restrições quanto à disponibilidade de mercado e de recursos para aquisição de água e nitrogênio, determinaram-se as quantidades ótimas desses insumos, conhecida a função de produção e os preços do produto e dos insumos. Denominou-se quantidade ótima do insumo àquela que maximiza a receita líquida, definida como a receita bruta da cultura menos os custos de produção no quinto ano do pomar. O problema consistiu em maximizar a seguinte função objetivo:

$$
\mathrm{Z}(\mathbf{W}, \mathbf{N})=\mathbf{P}_{\mathrm{CX}} \cdot \mathbf{Y}(\mathbf{W}, \mathbf{N})-\left\{\left[\frac{\mathrm{CFA}_{\mathbf{s}}+\mathrm{CE}(\mathbf{W})}{\mathbf{N a}}\right]+\left(\mathbf{P}_{\mathbf{N}} \cdot \mathbf{N}\right)+\left(\mathrm{CAT}_{\mathrm{p}}\right)+\left[\mathbf{P}_{\mathrm{c} 0} \cdot \mathbf{Y}(\mathbf{W}, \mathbf{N})\right]\right\}
$$

sendo:

$\mathbf{Z}(\mathbf{W}, \mathbf{N})$ - receita líquida da cultura, em função da água e do nitrogênio; $\mathrm{R} \$$ /árvore;

$\mathbf{P}_{\mathbf{C X}}$ - preço da laranja, $\mathrm{R} \$ /$ caixa;

$\mathbf{P}_{\mathbf{N}}$ - preço do nitrogênio, $\mathrm{R} \$ / \mathrm{g}$;

$P_{\text {Co - preço de colheita, } \mathrm{R} \$ / \text { caixa; }}$

CFA - custo fixo anual do sistema de irrigação, $\mathrm{R} \$ / \mathrm{ha}$;

CE(W) - custo variável da irigação, $R \$ / h a$;

Na - numero de árvores por hectare;

$\mathrm{CAT}_{\mathbf{p}}$ - custo anual do pomar, R\$/árvore. 


\subsection{Preços da laranja}

De acordo com as estimativas para os preços de laranja no mercado brasileiro realizados por Garcia (1993), o preço médio da caixa de laranja $(40,8 \mathrm{~kg})$ para indústria, projetado para o ano de 1996 foi de $\mathrm{R} \$$ 1,80/caixa. De acordo com informações de compradores de laranjas, o preço máximo foi de $\mathrm{R} \$ 3,00 /$ caixa para frutas de mesas.

Como ocorre variação do preço pago para os produtores em função da época do ano, da qualidade do fruto e da demanda do mercado, optou-se por trabalhar nesta faixa de preço $(R \$ 1,80$ a $R \$ 3,00)$ para definir as receitas brutas e líquidas, para fins industriais e consumo in natura.

\subsection{Custo de produção de laranja}

Os componentes de custo envolvidos na produção de laranja foram o custo do serviço da irrigação, custo do pomar, custo do nitrogênio e custo de colheita, por árvore. No nível $W_{0}$ (sem irrigação) não foi considerado o custo fixo do sistema de irrigação.

\subsubsection{Custo da irrigação}

O custo da irrigação por árvore, foi constituído pelo custo da energia elétrica consumida para bombear o volume de água aplicada por árvore, juros anuais de $6 \%$ 
sobre o valor empregado na aquisição do equipamento de irrigação ( $\mathrm{R} \$ 2.000,00 / \mathrm{ha}$ ), quota anual de amortização do capital investido para 10 anos de vida útil e os custos de manutenção e reparos do sistema de irrigação.

As principais opções de tarifas de formecimento de energia elétrica para 0 produtor rural, cobradas pela $\mathrm{CPFL}^{(2)}$, denominadas de verde, monômio convencional, binômio convencional e azul, estão apresentadas na Tabela 3.

Tabela 3. Tarifas de energia elétrica para uso rural, oferecidas pela CPFL.

\begin{tabular}{|c|c|c|c|c|}
\hline \multirow[t]{2}{*}{ Tipos de tarifa } & \multirow[t]{2}{*}{ Demanda $(\mathrm{R} \$ / \mathrm{kW})^{*}$} & \multicolumn{3}{|c|}{ Consumo (R\$kW.h) } \\
\hline & & $\mathrm{P}^{* *}$ & FP*** & $\mathrm{HR}^{* * * *}$ \\
\hline Verde & 3,321 & 0,290538 & 0,0227432 & 0,009144 \\
\hline Monômio convencional & 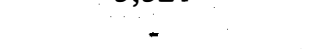 & 0,069670 & 0,069670 & 0,027868 \\
\hline Binômio convencional & 3,771 & 0,055143 & 0,055143 & 0,018381 \\
\hline Azul & 9,945 & 0,060417 & - & 0,009144 \\
\hline Azul Fora de Pico & 3,321 & - & 0,027432 & 0,009144 \\
\hline
\end{tabular}

* Demanda mensal

** Tarifa de energia elétrica para o horário de pico de consumo. É opcional para as concessionária escolher 3 horas entre as 17:00 e 22:00 horas dos dias úteis para definir o horário de pico de consumo.

*** Tarifa de energia elétrica para o horário normal de consumo fora de pico (entre 5:00 e 17:00 horas).

**** Tarifa de energia elétrica para o horário reservado, quando a concessionária pode oferecer tarifa reduzida, conforme portaria do DENAE $n^{\circ} 105$ de 03/04/92 (entre 21:00 e 5:00 horas).

A potência necessária na motobomba $(\mathbf{P})$ foi estimada em $0,980 \mathrm{~kW}$ [equação (8)], para uma unidade operacional contendo 120 árvores (360 árvores/ha). A altura manométrica foi de 50 m.c.a., vazão de 1 l/s e eficiência do conjunto de bombeamento de 50\%. A vazão do sistema foi estimada considerando-se um microaspersor aplicando 30 1/h por árvore [equação (8)].

${ }^{(2)}$ CPFL - Companhia Paulista de Força e Luz (Piracicaba SP). 


$$
\mathrm{P}=\frac{\gamma \mathrm{QH} \mathbf{H} \mathbf{1 0}^{-3}}{\mathrm{E}}
$$

sendo:

P-potência instalada, $\mathrm{kW}$;

$\gamma$ - peso específico da água, $9800 \mathrm{~N} / \mathrm{m}^{3}$;

Q - vazão do sistema, $\mathrm{m}^{3} / \mathrm{s}$;

H - altura manométrica, m; e

E - eficiência do conjunto motobomba, decimal.

a) Custo variável da irrigação

O dispêndio com energia elétrica durante o ciclo de produção anual do pomar foi obtido em função da demanda de potência e do consumo efetivo de energia [equação (9)]. O custo da demanda de potência em 1 ha foi estimado em função da potência instalada, da tarifa mensal de demanda e do número de meses em que houve demanda de potência. O custo do consumo de energia para 1 ha foi estimado pelo produto entre potência consumida por hora, número de horas de operação no ano, e tarifa de consumo.

$$
C E(W)=P . T d . N m+P . T c . t
$$

sendo:

Td - tarifa de demanda de energia, $\mathrm{R} \$ / \mathrm{kW}$; 
Nm - número de meses no ano com demanda de potência;

Tc - tarifa de consumo de energia (R\$/kW.h); e

$\mathbf{t}$ - tempo de operação do sistema, horas.

b) Custo fixo da irrigação

$\mathrm{O}$ preço do equipamento de irrigação por microaspersão ( $\mathrm{R} \$ 2.000,00 / \mathrm{ha}$ ) foi obtido mediante consultas a revendedores, além de estimativas baseadas em valores médios de equipamentos em operação.

O valor do juro sobre o capital investido foi calculado conforme Neves e Shirota (1986), que recomendam trabalhar com uma estimativa representada pela média do valor do equipamento novo [equação (10)]. Foi utilizada a taxa de juro de $6 \%$ ao ano para financiamento. Esta taxa é a mesma cobrada pelo Banco do Brasil S/A, em 1997.

sendo:

$$
\mathrm{JSC}_{\mathrm{S}}=\frac{\mathrm{Ci}_{\mathrm{s}} \cdot \mathrm{r}}{2}
$$

JSC $_{\mathbf{S}}$ - juro anual sobre o capital investido no sistema de irrigação, R\$;

Cis - valor inicial do sistema de irrigação, $R \$$; e

$\mathbf{r}$ - taxa anual de juro, em decimal.

A depreciação do sistema foi calculada pelo método do fundo de amortização proposto por Coelho (1979), conforme a equação (11). A depreciação calculada por este 
critério permite que o capital seja substituído sem que se utilize recursos particulares ou crédito. O período de amortização do capital foi estimado em 10 anos.

$$
D_{s}=\frac{C i_{s} \cdot r}{(1+r)^{n}-1}
$$

sendo:

$\mathbf{D}_{\mathrm{S}}$ - cota anual de depreciação, $\mathrm{R} \$$

n - vida útil do sistema, anos.

O custo de reparos e manutenção do sistema foi estimado em $1,5 \%$ ao ano sobre o capital inicial, de acordo com Marin et al. (1968) [equação (12)]. Este valor é 2,31 vezes maior do que o proposto por Brito e Scaloppi (1986) para irrigação por aspersão convencional.

sendo:

$$
\mathrm{MR}_{\mathrm{S}}=\mathrm{T}_{\mathrm{MRS}} \cdot \mathrm{Ci}_{\mathrm{S}}
$$

$\mathrm{MR}_{\mathrm{S}}$ - custo fixo anual com reparos e manutenção do sistema, R\$.

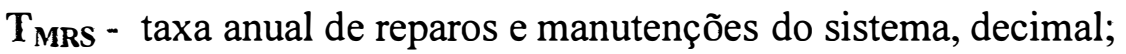

O custo fixo total anual do sistema de irrigação foi calculado pela equação (13), sendo constituído do juro sobre o capital empregado, da depreciação do equipamento em 10 anos de uso e do custo anual com reparos e manutenção.

$$
\mathrm{CFA}_{\mathrm{S}}=\mathrm{JSC}_{\mathrm{S}}+\mathrm{D}_{\mathrm{S}}+\mathrm{MR}_{\mathrm{S}}
$$


O custo do serviço da irrigação por árvore foi definido conforme a equação (14), onde somente o custo da energia elétrica consumida no bombeamento varia com o volume de água aplicada, enquanto o custo fixo do sistema é considerado constante.

$$
\mathbf{C S I}=\frac{\mathbf{C F A}_{\mathbf{S}}+\mathbf{C E}(\mathbf{W})}{\mathbf{N a}}, \text { para } 1440 \leq \mathrm{W} \leq 8640 \text { l/árvore }
$$

sendo:

CSI - custo da irrigação, R\$/árvore;

\subsubsection{Custo do pomar}

As despesas por árvore do pomar (Tabela 4) foram obtidas a partir das despesas com investimento (implantação) e custeio (manutenção) de um hectare de laranjeira (360 árvores), fornecidos pela COCAMAR CITRUS S/A. Considerou-se que durante os quatro primeiros anos de condução do pomar não há produção de laranja e que o mesmo tem vida útil de 21 anos, totalizando 25 anos de ocupação da área. O custo da terra não foi considerado neste cálculo.

a) Custo de implantação do pomar

A implantação do pomar foi concluída em quatro anos, totalizando um investimento de $\mathrm{R} \$ 10,10$ por árvore (Tabela 5), amortizados em 21 anos. Os valores 
anuais do juro sobre o capital investido no pomar $\left(\mathbf{J S C}_{\mathbf{p}}\right)$ e da depreciação $\left(\mathbf{D}_{\mathbf{p}}\right)$ foram calculados da forma como expresso nas equações (10) e (11).

Tabela 4. Despesas anuais de implantação do pomar $\left(1 .^{\circ}\right.$ ao $4 .^{\circ}$ ano $)$ e de custeio $\left(5 .^{\circ}\right.$ e $6 .^{\circ}$ anos).

\begin{tabular}{|c|c|c|c|c|c|c|}
\hline \multirow[t]{2}{*}{ ITENS } & \multicolumn{6}{|c|}{ Anos } \\
\hline & $1^{0}$ & $2^{0}$ & $3^{0}$ & $4^{0}$ & $5^{0}$ & $6^{0}$ \\
\hline & \multicolumn{4}{|c|}{$\begin{array}{c}\text { Despesas de implantação } \\
\text { CIP (RS/árvore) }\end{array}$} & \multicolumn{2}{|c|}{ Despesas de custeio } \\
\hline Máq. e equip. & 0,97 & 0,44 & 0,64 & 0,73 & 0,77 & 0,84 \\
\hline Mão-de-obra & 0,50 & 0,26 & 0,30 & 0,32 & 0,33 & 0,31 \\
\hline Insumos & 1,83 & 0,48 & 0,91 & 1,26 & 1,63 & 1,89 \\
\hline Total & 3,30 & 1,18 & 1,85 & 2,31 & 2,73 & 3,04 \\
\hline
\end{tabular}

Tabela 5. Valor do investimento para implantação do pomar (R $\$$ /árvore).

\begin{tabular}{|c|c|c|c|c|}
\hline Anos de implantação do pomar & $1^{\circ}$ & $2^{\circ}$ & $3^{\circ}$ & $4^{\circ}$ \\
\hline Despesas com máquinas e equipamentos $(A)$ & 0,970 & 0,440 & 0,640 & 0,730 \\
\hline Despesas com mão-de-obra (B) & 0,500 & 0,260 & 0,300 & 0,320 \\
\hline Despesas com insumos (C) & 1,830 & 0,480 & 0,910 & 1,260 \\
\hline$(A+B+C)=C_{i}$ & 3,300 & 1,180 & 1,850 & 2,310 \\
\hline $\mathrm{I}_{\mathrm{i}-1}$ & 0,000 & 3,498 & 4,959 & 7,220 \\
\hline$C_{i}+I_{i-1}$ & 3,300 & 4,678 & 6,809 & 9,530 \\
\hline JSC (6\% aa) & 0,198 & 0,281 & 0,409 & 0.572 \\
\hline $\mathrm{I}_{\mathrm{i}}$ & 3,498 & 4,959 & 7,220 & 10,10 \\
\hline
\end{tabular}

O valor do investimento foi obtido a partir das despesas anuais acrescidas de juros sobre o capital imobilizado, sendo este capital corrigido anualmente durante os quatro primeiros anos de condução do pomar [equação (15)].

$$
I_{i}=\left(J S C_{p}+1\right)\left(C I P_{i}+I_{i-1}\right)
$$


sendo:

$\mathbf{I}_{\mathbf{i}}$ - valor do investimento anual no pomar, no ano $\mathbf{i},\left(\mathbf{I}_{\mathbf{0}}=0\right), \mathrm{R} \$$

$\mathbf{C I P}_{\mathbf{i}}$ - despesas de implantação do pomar no ano i, R\$; e

i - anos de implantação do pomar, 1, 2, 3, 4 .

Durante o período de implantação do pomar, não foram computados os custos de amortização do capital. No entanto, foram computados os juros de $6 \%$ ao ano sobre o capital. Esse investiments ao final do quarto ano foi considerado o capital investido.

b) Custo de manutenção do pomar

O custeio anual do pomar foi estimado para o $5^{\circ}$ ano, conforme a planilha de despesas da COCAMAR CITRUS S/A (Tabela 4) acrescida de juros de $12 \%$ ao ano. As despesas com cüsteio foram projetadas para serem saldadas no prazo de um ano, admitindo-se que este é o ciclo de produção do pomar. A seguinte expressão foi utilizada:

$$
\mathrm{CP}_{\mathrm{p}}=\mathrm{CPP}(1+\mathrm{JC})
$$

sendo:

$\mathrm{CP}_{\mathbf{p}}$ - custeio anual do pomar, $\mathrm{R} \$$ /árvore;

CPP - despesas anuais com o pomar, R\$/árvore;

JC - taxa anual de juros para custeio, decimal. 
O custo anual total do pomar (CA $\left.\mathbf{T}_{\mathbf{p}}\right)$ foi calculado pela equação (17).

$$
\mathrm{CAT}_{\mathbf{P}}=\mathrm{JSC}_{\mathrm{P}}+\mathrm{D}_{\mathrm{P}}+\mathrm{CP}_{\mathrm{P}}
$$

3.10.3 Custo do nitrogênio

Considerou-se o custo do nitrogênio igual a $\mathrm{R} \$ 0,93 / \mathrm{kg}$, relativo ao preço de mercado na região de Maringá, PR, em setembro de 1996, com base no preço da uréia de $\mathrm{R} \$ 0,37 / \mathrm{kg}$.

3.10.4. Custo da colheita

O custo da colheita foi definido a partir do preço pago para a colheita de uma caixa de laranja na região de Limeira SP $(\mathrm{R} \$ 0,70 / \mathrm{cx})$. 


\section{RESULTADOS E DISCUSSÃO}

4.1. Número de frutos durante o ciclo de produção.

Na Figura 9 apresenta-se o número de frutos por árvore, contados no final da floração (última semana de agosto de 1995), no final da frutificação (última semana de setembro de 1995) e na colheita (mês de julho de 1996). Os maiores números de frutos por árvore ocorreram nos tratamentos $\mathrm{W}_{3}$ (90 litros de água por árvore) e $\mathrm{W}_{4}$ (120 litros de água por árvore).

Observou-se que a queda de frutos foi mais acentuada nos tratamentos de irrigação que apresentaram maior número de frutos na colheita (Figura 9). Este fato também foi observado por Hilgeman (1977) e Guardiola (1992).

Nos tratamentos $\mathrm{W}_{3}$ e $\mathrm{W}_{4}$ (Figura 9) o número de frutos por árvore destacou-se dos demais nas três épocas de contagem (agosto de 1995, setembro de 1995 e julho de 1996). Com isto pode-se afirmar que a irrigação é uma das causas do acréscimo de produção de frutos por árvore. 


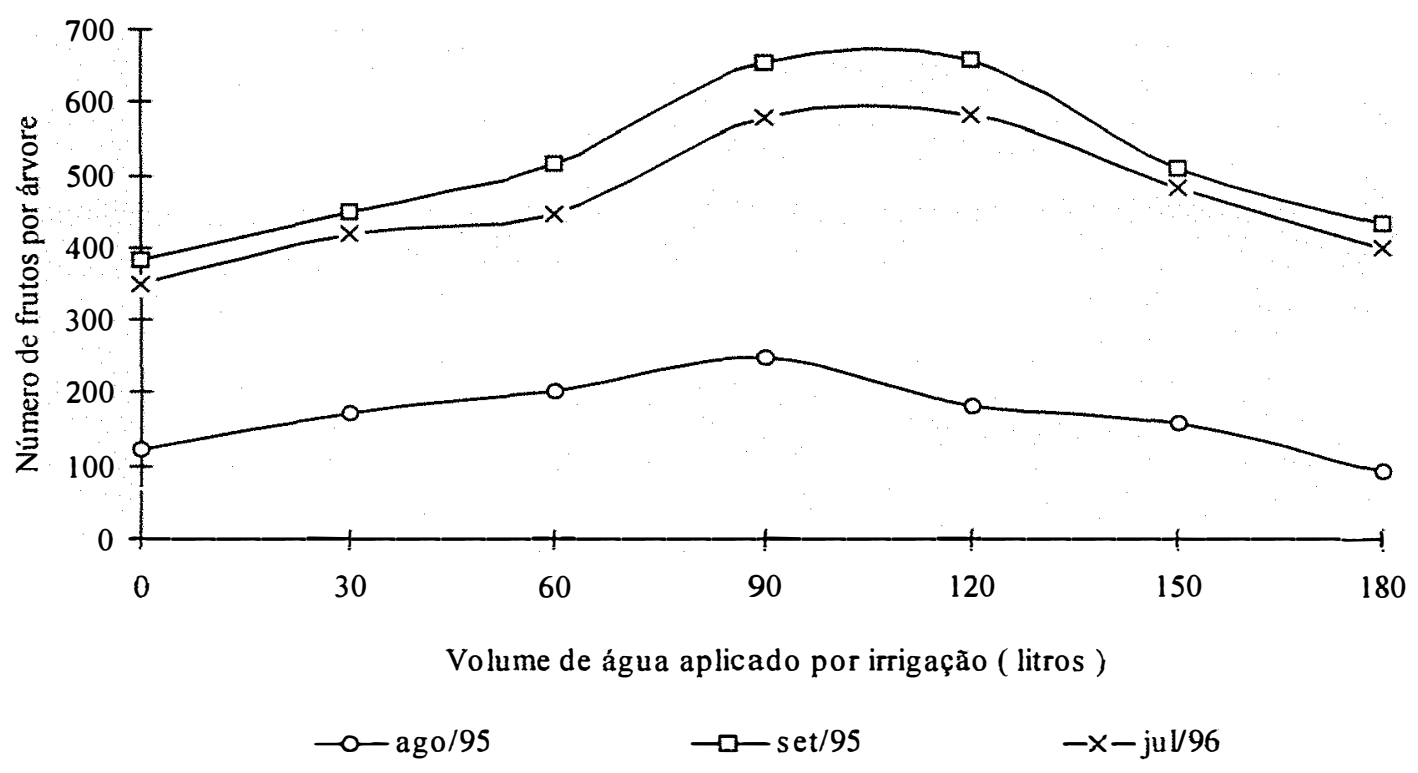

Figura 9. Médias por tratamento, do número de frutos por árvore, no final do florescimento (agosto de 1995), no final da frutificação (setembro de 1995) e na colheita ( julho de 1996), em função dos volumes de água aplicados por irrigação.

Não foi a queda de frutos, por déficit ou excesso de água a principal causa da redução do número de frutos, como sugerem Koo (1979) e Giorgi et al. (1991), mas sim o número de frutos produzidos, conforme Higelman (1977) também observou.

A redução do número de frutos causada pelo excesso de água nos tratamentos $W_{5}$ e $\mathrm{W}_{6}$ pode ter ocorrido devido a deficiência de oxigênio no solo, conforme relatam Castro (1994) e Marsh (1968) ou pela redução da temperatura do solo devido à irrigação, segundo Giriton (1927). 
A figura 9 mostra o acréscimo do número de frutos por árvore entre agosto e setembro de 1995 nos diversos tratamentos de irrigação. Observa-se também redução do número de frutos entre setembro de 1995 e a época de colheita (julho de 1995).

As porcentagens de redução do número de frutos por árvore, de setembro de 1995 (final da fase de frutificação) para julho de 1996 (época da colheita) foram de 8,1; 7,1; 13,$8 ; 13,3 ; 11,3 ; 5,1$ e $7,9 \%$, respectivamente para os tratamentos $W_{0}, W_{1}, W_{2}, W_{3}, W_{4}$, $\mathrm{W}_{5}$ e $\mathrm{W}_{6}$. Esses valores não podem ser caracterizados como o fenômeno denominado "June Drop", pois, nos tratamentos onde se aplicou menor quantidade de água a queda de frutos foi relativamente pequena, da ordem de 8,$1 ; 7,1 ; 13,8$ e $13,3 \%$.

No caso dos tratamentos $\mathrm{W}_{0}, \mathrm{~W}_{1}, \mathrm{~W}_{5}$ e $\mathrm{W}_{6}$, a menor queda de frutos deve-se provavelmente ao reduzido número de frutos por árvore, que indiretamente afetaram o número de frutos caídos. Havendo menos frutos por árvore, haverá menor demanda por água e consequentemente menor queda de frutos.

Guardiola (1992) afirma que a maioria das flores produzidas cai, aborta, ou não são fecundadas e que esta ocorrência é função da disponibilidade de água no solo. Giorgi et al. (1991) estimaram em 2,5\% o número de flores que se transformam em frutos no final da frutificação e que determina a produtividade do número de frutos durante a colheita, em cultura não irrigada. Koo e Reese (1974) e Hilgeman (1977) comentam que também pode haver queda de frutos se no final da primavera e início de verão ocorrer déficit hídrico no solo. 
Na Figura 10 apresenta-se o número de frutos por árvore, contados no final da floração (última semana de agosto de 1995), no final da frutificação (última semana de setembro de 1995) e na colheita (mês de julho de 1996), em função das doses de nitrogênio. Os maiores números de frutos por árvore ocorreram no tratamento $\mathrm{N}_{3}(7,5 \mathrm{~g}$ de nitrogênio por planta, semanalmente) e os menores no tratamento $\mathrm{N}_{0}$.

As porcentagens de frutos caídos no período de setembro de 1995 a julho de 1996 , foram 7,$4 ; 7,2 ; 3,0 ; 14,4 ; 12,1$ e $12,2 \%$, respectivamente para os tratamentos $\mathrm{N}_{0}$ $\mathrm{N}_{1}, \mathrm{~N}_{2}, \mathrm{~N}_{3}, \mathrm{~N}_{4}$ e $\mathrm{N}_{5}$

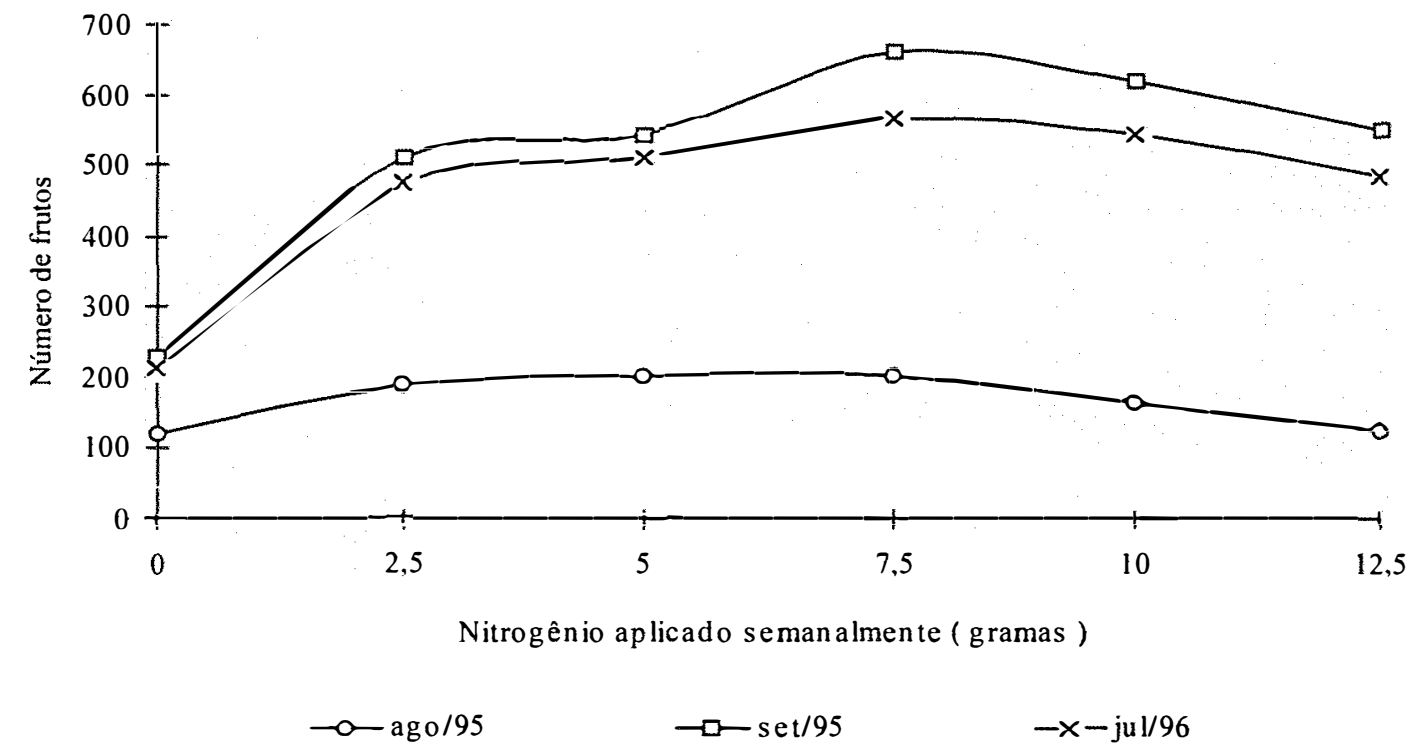

Figura 10 - Médias por tratamento do número de frutos por árvore, no final do florescimento (agosto de 1995), no final da frutificação (setembro de 1995) e na colheita (julho de 1996), em função das doses de nitrogênio aplicadas semanalmente. 
O número de frutos caídos foi semelhante para os três tratamentos de maiores doses de $\mathrm{N}$, mas estes tratamentos também apresentaram o maior acréscimo de número de frutos entre as contagens de agosto e setembro de 1995.

4.2. Número de frutos colhidos por árvore

Na Tabela 6 encontram-se os valores médios do número de frutos colhidos por árvore, em função dos volumes de água de irrigação e das doses de nitrogênio. O maior valor (690 frutos por árvore) foi obtido no tratamento $\mathrm{N}_{3} \mathrm{~W}_{4}(322,5 \mathrm{~g}$ de $\mathrm{N}$ e $5760 \mathrm{l}$ de água por árvore). O menor valor (120 frutos por árvore) foi observado no tratamento $\mathrm{N}_{0} \mathrm{~W}_{6}$ (ausência de adubação nitrogenada e aplicação de 8640 litros de água por árvore). Não houve efeito significativo da interação entre água e nitrogênio na análise de variância dos desdobramentos da regressão, pelo teste de "F" (Tabela 7). O desdobramento quadrático foi considerado o de maior ordem, significativo ao nível de $1 \%$ de probabilidade pelo teste de "F". O quadrado médio da falta de ajustamento do efeito da irrigação foi significativo ao nível de $5 \%$ de probabilidade, podendo então considerar-se a alternativa de outros modelos de ajustamento (grau superior a 2) para explicar o efeito deste tratamento sobre a produção de laranja pêra (Citrus sinensis Osbeck vr. Pêra). 
Tabela 6. Valores médios do número de frutos colhidos por árvore

\begin{tabular}{lcccccccc}
\hline $\begin{array}{l}\text { Níveis de } \\
\text { nitrogênio }\end{array}$ & \multicolumn{8}{c}{ Volumes de irrigação (l/árvore) } \\
\cline { 2 - 9 }$(\mathrm{g} /$ árvore $)$ & $\mathrm{W}_{0}(0)$ & $\mathrm{W}_{1}(1440)$ & $\mathrm{W}_{2}(2880)$ & $\mathrm{W}_{3}(4320)$ & $\mathrm{W}_{4}(5760)$ & $\mathrm{W}_{5}(7200)$ & $\mathrm{W}_{6}(8640)$ & Média \\
\hline $\mathrm{N}_{0}(0)$ & 129 & 201 & 234 & 367 & 251 & 189 & 120 & 213,0 \\
$\mathrm{~N}_{1}(107,5)$ & 305 & 361 & 378 & 515 & 634 & 587 & 543 & 474,7 \\
$\mathrm{~N}_{2}(215)$ & 398 & 393 & 450 & 654 & 654 & 498 & 523 & 510,0 \\
$\mathrm{~N}_{3}(322,5)$ & 567 & 478 & 601 & 658 & 690 & 602 & 356 & 564,6 \\
$\mathrm{~N}_{4}(430)$ & 387 & 579 & 519 & 660 & 648 & 521 & 479 & 541,9 \\
$\mathrm{~N}_{5}(537,5)$ & 323 & 497 & 486 & 617 & 613 & 487 & 368 & 484,4 \\
\hline Média & 351,5 & 418,2 & 444,7 & 578,5 & 581,7 & 480,7 & 398,2 & \\
\hline
\end{tabular}

Tabela 7. Análise de variância dos tratamentos e seus desdobramentos, da regressão e dos coeficientes da regressão para número de frutos colhidos por árvore

\begin{tabular}{|c|c|c|c|c|c|}
\hline \multicolumn{6}{|c|}{ ANÁLISE DE VARIÂNCIA DOS DESDOBRAMENTOS DA REGRESSÃO } \\
\hline Fonte de variação & G.L & S.Q. & Q.M. & $\mathbf{F}$ & $\mathbf{R}^{2}$ \\
\hline Nitrogênio & 5 & 572753,9 & 114550,8 & $25,194^{* *}$ & \\
\hline Efeito linear & 1 & 260223,1 & 260223,1 & $57,232 * *$ & 0,45 \\
\hline Efeito Quadrático & 1 & 278378,2 & 278378,2 & $61,225 * *$ & 0,94 \\
\hline Falta de ajustamento & 3 & 34151,4 & 11383,8 & $2,504 \mathrm{NS}$ & \\
\hline Água & 6 & 280165,0 & 46694,7 & $10,270 * *$ & \\
\hline Efeito linear & 1 & 34629,6 & 34629,6 & $7,616 * *$ & 0,12 \\
\hline Efeito Quadrático & 1 & 193208,9 & 193208,9 & $42,492 * *$ & 0,81 \\
\hline Falta de ajustamento & 4 & 52326,5 & 13081,6 & $2,877 *$ & \\
\hline Resíduo & 30 & 136404,8 & 4546,8 & & \\
\hline $\mathrm{CV}=14,5 \%$ & & & & & \\
\hline \multicolumn{6}{|c|}{ ANÁLISE DE VARIÂNCIA DA REGRESSÃO } \\
\hline Fonte de variação & G.L. & S.Q. & Q.M. & $\mathbf{F}$ & \\
\hline Devido à regressão & 4 & 1058,0 & 529,0 & $9,790^{* *}$ & \\
\hline Erro & 37 & 2106,7 & 54,0 & & \\
\hline $\mathrm{R}^{2}=\overline{0} \overline{\overline{7}} \overline{504}$ & & & & & \\
\hline \multicolumn{6}{|c|}{ ESTIMATIVA DOS PARÁMETROS DA REGRESSÃO $Y=Y(W, N)$} \\
\hline Coeficiente & Valor & & Erro Padrão & Valor "t" & \\
\hline Constante & 99,77 & & & & \\
\hline Linear do nitrogênio & 1,946 & & 0,2326 & 8,3683 & \\
\hline Quadrático do nitrogênio & $-0,002$ & & 0,0004154 & $-6,7980$ & \\
\hline Linear da água & 0,091 & & 0,01499 & 6,1062 & \\
\hline Quadrático da água & $-0,000$ & ** & 0,000001667 & $-5,6634$ & \\
\hline
\end{tabular}


$\mathrm{Na}$ ausência de adubação nitrogenada o maior número de frutos por árvore foi alcançado com o tratamento $\mathrm{W}_{3}(4320$ 1/árvore $)$ e o menor com o tratamento $\mathrm{W}_{6}(8640$ 1/árvore), respectivamente 367 e 120 frutos por árvore.

$\mathrm{Na}$ ausência de irrigação complementar, o maior número de frutos por árvore foi alcançado com o tratamento $\mathrm{N}_{3}(322,5$ g/árvore $)$ e o menor com o tratamento $\mathrm{N}_{0}$ (ausência de adubação nitrogenada), respectivamente 567 e 129 frutos por árvore. A diferença relativa entre estes valores é de 77,3\%.

A equação de regressão encontrada para estimar o número de frutos na colheita (equação 18) é significativa ao nível de $1 \%$ de probabilidade pelo teste de "F", com um coeficiente de determinação de $75,04 \%$, sendo os parâmetros da equação também significativos a $1 \%$ de probabilidade (Tabela 7 ).

$$
\begin{aligned}
& N F=99,8+1,95 N-2,82 \cdot 10^{-3} N^{2}+9,16 \cdot 10^{-2} W-9,44 \cdot 10^{-6} W^{2} \\
& R^{2}=0,7504
\end{aligned}
$$

em que:

NF - número de frutos na colheita;

$\mathbf{N}$ - quantidade total de nitrogênio aplicado durante o ciclo de produção, g/árvore; e W - volume total de água aplicado pela irrigação, durante o ciclo de produção, 1/árvore.

Observa-se na equação 18 que para cada unidade de nitrogênio acrescentada, ocorre um aumento linear da produção de frutos por árvore na ordem de 1,95 unidades e uma redução no parâmetro quadrático de $2,82.10^{-3}$ frutos e que para cada unidade de 
água acrescentada ocorre um acréscimo linear de $9,16.10^{-2}$ frutos por árvore e uma redução devido ao parâmetro quadrático na ordem de $9,44.10^{-6}$ frutos.

Na Equação 18, a constante do parâmetro linear é maior para nitrogênio do que para água, o que acarreta maior valor do número de frutos por árvore devido a adição de uma unidade de nitrogênio do que devido a adição de uma unidade de água. O efeito quadrático sobre o número de frutos produzidos por árvore também é maior devido ao efeito do nitrogênio do que devido ao efeito da água.

A superfície de resposta e as curvas de isoproducão relativos à equação 18 estão apresentadas nas Figuras 11 e 12, onde se observa a distribuição espacial dos valores estimados. O número máximo de frutos por árvore estimado foi 659,1 para um volume de água de irrigação de 4851,7 1/árvore e uma dose de nitrogênio de 345,7 g/árvore. O menor número de frutos $(99,8)$ foi estimado na ausência de irrigação e de adubação nitrogenada. Neste caso, a diferença relativa entre os valores de número de frutos foi de $84,8 \%$.

Koo (1979), Hilgeman (1977) e March (1968) citam que a produção de frutos por árvore é função da quantidade de água aplicada e da época do ano que a irrigação é conduzida. Estes autores também são de consenso que não é necessário que se mantenha a cultura irrigada durante todo o ciclo de produção, devendo-se realizar irrigações no vingamento e na fixação dos frutinhos (final de inverno, primavera e início de verão).

Alguns autores (March, 1968; Koo, 1977; Hilgeman, 1977e Koo, 1980) tratam da irrigação de laranja como uma técnica utilizada para reduzir a queda de frutos. Neste 


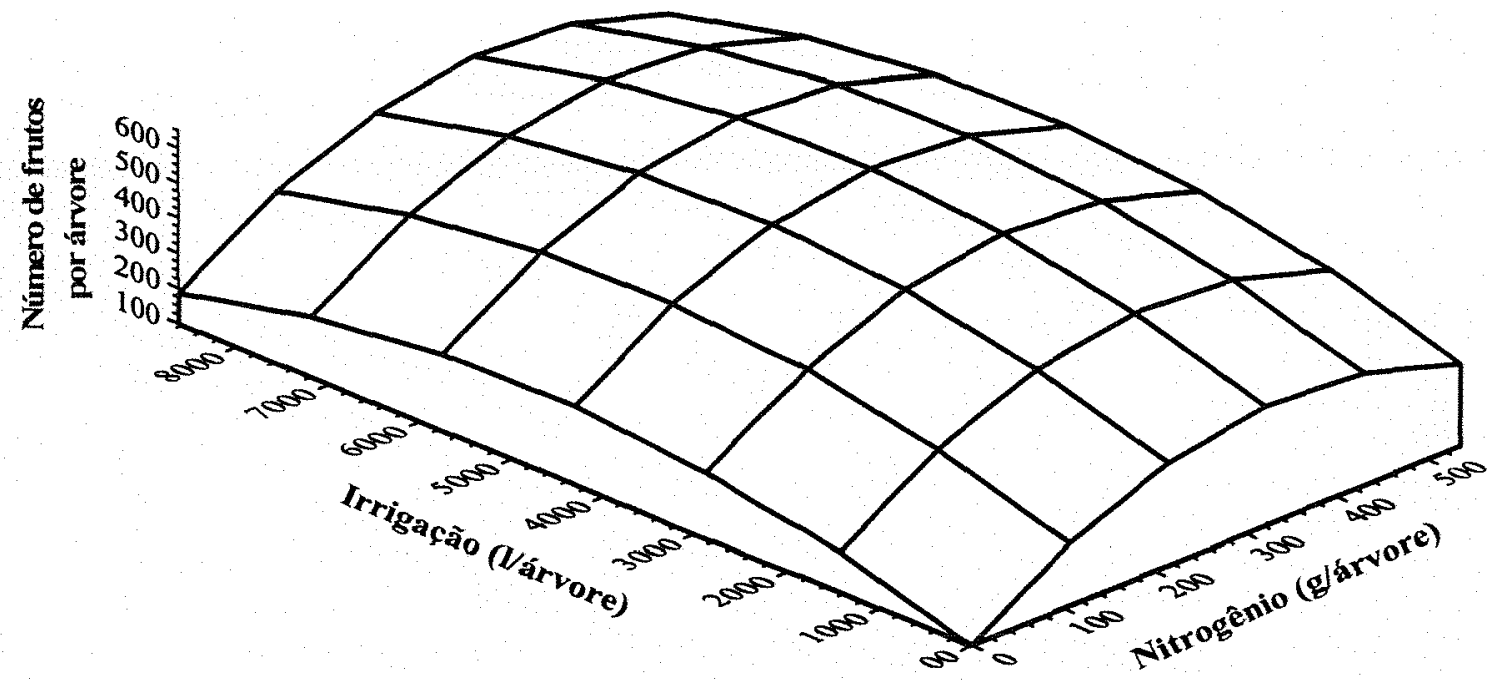

Figura 11. Superfície de resposta para número de frutos colhidos em função da irrigação e adubação nitrogenada

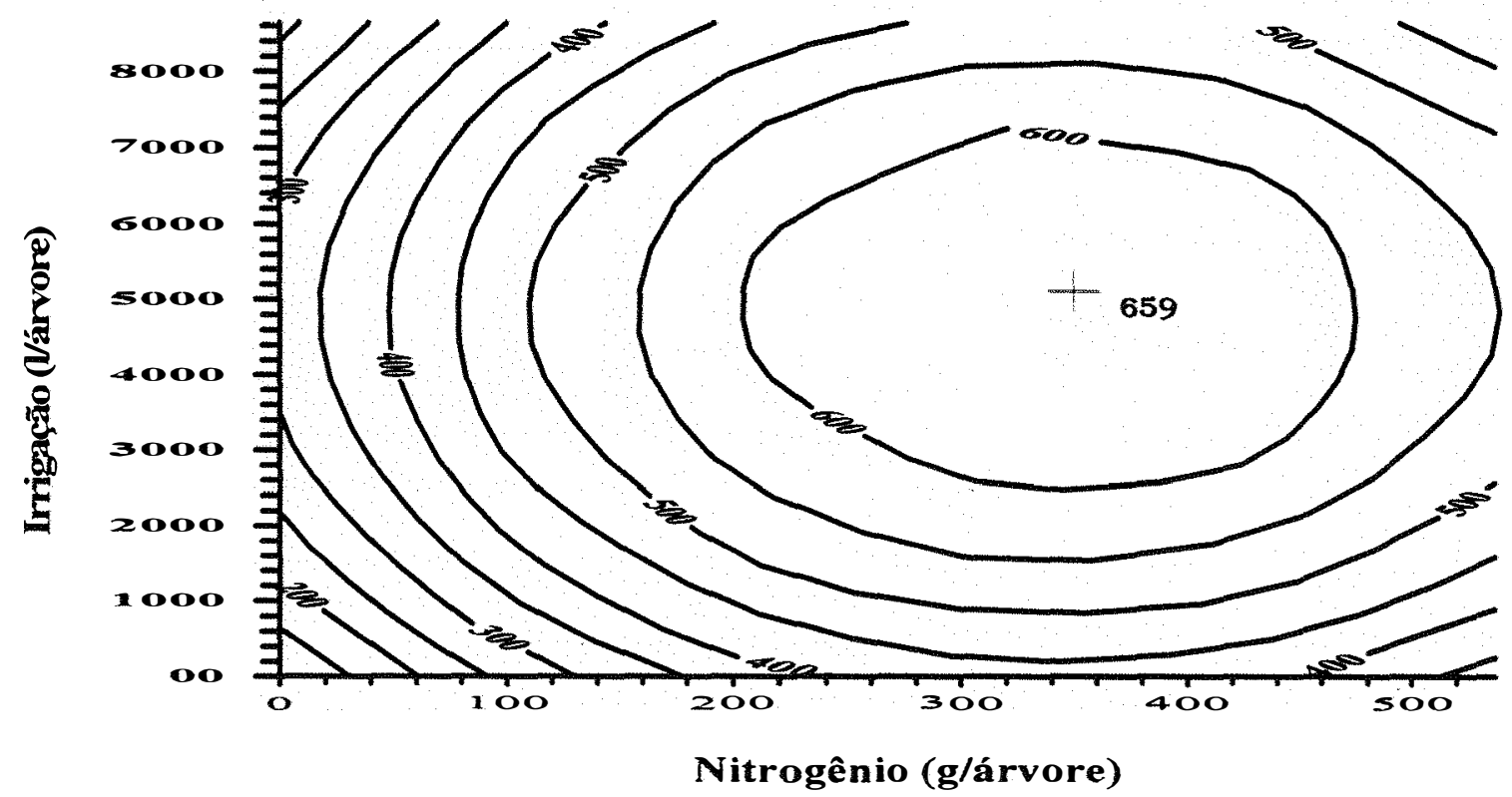

Figura 12. Curvas de isoprodução para número de frutos colhidos em função da irrigação e adubação nitrogenanda 
trabalho, observou-se que os frutos foram produzidos em função dos insumos aplicados e que a queda de frutos não foi determinante para a redução da produtividade. Ainda foi possível observar que a irrigação para produção de laranja pode ser planejada para o período de julho a novembro, como sugerem os autores que trabalharam com o efeito do déficit hídrico na produção de citrus (Koo, 1980 ; Hilgeman, 1977), pois entre dezembro a abril as chuvas são mais freqüentes.

Caso o sistema de irrigação seja fixo, havendo deficiência hídrica em outras épocas de produção, é conveniente realizar irrigação para manter as plantas vigorosas e menos suscetíveis ao ataque de pragas e doenças, pois conforme observa Koo (1979), diferenças de produção não significativas em um ciclo de produção podem vir a ser significativas quando se analisa a produção acumulada de um período maior de ciclos.

A cultura do citrus depende de um período de seca entre abril e junho, para ser estimulada a emitir as flores, e de um período sem deficiência hídrica, imediatamente após o florescimento, para que a florada e a frutificação sejam uniformes, fato que não ocorre regularmente em condições normais de clima, conforme afirma Tubelis (1991). Assim, a irrigação possibilita um planejamento mais adequado das produções, proporcionando colheitas mais concentradas (Goell, 1992).

Mungomery et al. (1978) e Haag et al. (1993) concluíram que a adubação nitrogenada deve ser feita antes da emissão de ramos e consequentemente da produção de frutos. No entanto, conforme observa Koo (1979) o nitrogênio também influencia o crescimento dos frutos e a fixação dos mesmos. 
Sharples e Hilgeman (1969) encontraram valores médios de número frutos por árvore crescentes em função dos níveis de nitrogênio, conforme neste trabalho, e destacaram que laranjeiras irrigadas são mais eficientes no aproveitamento do nitrogênio. Bielorai et al. (1984) trabalhando com laranja Shamouti (Citrus sinensis L.) irrigada, com 16 anos de idade e aplicando 240, 408 e 774 g de N/árvore, colheram, respectivamente, 737, 890 e 986 frutos por árvore, destacando o efeito do nitrogênio.

As doses de nitrogênio que maximizam a produção de frutos, apontadas na literatura, variam com o solo, com a cultivar e com manejo do pomar. De qualquer forma, a adubação nitrogenada não pode ser analisada independente da água aplicada, pois é em solução que o nitrogênio é transportado até a zona radicular. Além disso, o nitrogênio é facilmente volatilizado e lixiviado pelo excesso de água. Dessa forma, os efeitos dos níveis de nitrogênio sempre são corretamente avaliados.

\subsection{Peso médio do fruto na colheita}

$\mathrm{Na}$ Tabela 8 encontram-se os valores médios de peso do fruto, em função dos volumes de água de irrigação e das doses de nitrogênio. O maior valor $(216,5 \mathrm{~g})$ foi obtido no tratamento $\mathrm{N}_{2} \mathrm{~W}_{6}$ (215 g de $\mathrm{N}$ e $8640 \mathrm{l}$ de água por árvore) e o menor $(162,5 \mathrm{~g})$ na ausência de nitrogênio e irrigação. A diferença relativa entre estes valores foi de $24,9 \%$. 
Tabela 8. Valores médios do peso do fruto $(\mathrm{g})$.

\begin{tabular}{lcccccccc}
\hline $\begin{array}{c}\text { Níveis de } \\
\text { nitrogênio }\end{array}$ & \multicolumn{7}{c}{ Volumes de irrigação (l/árvore) } \\
\cline { 2 - 10 } g/árvore & $\mathrm{W}_{0}(0)$ & $\mathrm{W}_{1}(1440)$ & $\mathrm{W}_{2}(2880)$ & $\mathrm{W}_{3}(4320)$ & $\mathrm{W}_{4}(5760)$ & $\mathrm{W}_{5}(7200)$ & $\mathrm{W}_{6}(8640)$ & Média \\
\hline $\mathrm{N}_{0}(0)$ & 162,5 & 173,7 & 177,7 & 181,0 & 176,6 & 199,7 & 164,2 & 176,5 \\
$\mathrm{~N}_{1}(107,5)$ & 174,4 & 183,0 & 176,6 & 185,6 & 194,0 & 208,3 & 185,4 & 186,8 \\
$\mathrm{~N}_{2}(215)$ & 187,5 & 192,7 & 196,0 & 200,6 & 211,9 & 210,0 & 216,5 & 202,2 \\
$\mathrm{~N}_{3}(322,5)$ & 180,0 & 199,8 & 196,2 & 184,4 & 210,2 & 203,0 & 214,7 & 198,3 \\
$\mathrm{~N}_{4}(430)$ & 191,3 & 201,9 & 193,5 & 194,6 & 181,9 & 188,7 & 203,7 & 193,8 \\
$\mathrm{~N}_{5}(537,5)$ & 194,1 & 202,5 & 183,2 & 202,9 & 195,7 & 204,9 & 200,0 & 197,6 \\
\hline Média & 181,6 & 192,3 & 187,2 & 191,5 & 195,1 & 202,4 & 197,4 & \\
\hline
\end{tabular}

A análise de variância dos desdobramentos da regressão mostrou efeito não significativo para interação entre água e nitrogênio, pelo teste de "F". Os desdobramentos quadrático para nitrogênio e linear para água, foram considerados os de maiores ordens, ambos significativos ao nível de $1 \%$ de probabilidade pelo teste de "F".

$\mathrm{Na}$ ausência da adubação nitrogenada, o maior peso médio do fruto ocorreu no tratamento $\mathrm{W}_{5}$ (7200 l/árvore) e o menor em $\mathrm{W}_{0}$ (ausência de irrigação) respectivamente 199,7 e 162,5 gramas por fruto. A diferença relativa entre estes valores é de $18,6 \%$. Na ausência da irrigação, o maior peso do fruto foi alcançado no tratamento $\mathrm{N}_{5}(537,5$ g/árvore) e o menor em $\mathrm{N}_{0}$, respectivamente 194,1 e $162,5 \mathrm{~g} /$ fruto. A diferença relativa entre estes valores é de $16,3 \%$.

Em $\mathrm{W}_{0}$, o peso médio do fruto apresenta uma tendência linear crescente em relação ao aumento das doses de nitrogênio (Tabela 8), mas apresenta tendências quadráticas quando foram realizadas irrigações complementar. 
Tabela 9. Análise de variância dos tratamentos e seus desdobramentos, da regressão e dos coeficientes da regressão, para peso do fruto

\begin{tabular}{|c|c|c|c|c|c|}
\hline \multicolumn{6}{|c|}{ ANÁLISE DE VARIÂNCIA DOS DESDOBRAMENTOS DA REGRESSÃO } \\
\hline Fonte de variação & G.L & S.Q. & Q.M. & $\mathbf{F}$ & $\mathbf{R}^{2}$ \\
\hline Nitrogênio & 5 & 3111,1 & 622,2 & $7,803 * *$ & \\
\hline Efeito linear & 1 & 1500,6 & 1500,0 & $18,819 * *$ & 0,48 \\
\hline Efeito Quadrático & 1 & 1043,7 & 1043,7 & $13,090 * *$ & 0,82 \\
\hline Falta de ajustamento & 3 & 566,7 & 188,9 & $2,369 \mathrm{NS}$ & \\
\hline Água & 6 & 1659,3 & 276,5 & $3,468 * *$ & \\
\hline Efeito linear & 1 & 1222,6 & 1222,6 & $15,332 * *$ & 0,74 \\
\hline Efeito Quadrático & 1 & 22,0 & 22,0 & $0,276 \mathrm{NS}$ & 0,75 \\
\hline Falta de ajustamento & 4 & 414,46 & 103,61 & $1,299 \mathrm{NS}$ & \\
\hline Resíduo & 30 & 2392,1 & 79,7 & & \\
\hline \multicolumn{6}{|l|}{$C V=4,64 \%$} \\
\hline \multicolumn{6}{|c|}{ ANÁLISE DE VARIÂNCIA DA REGRESSÃO } \\
\hline Fonte de variação & G.L. & S.Q. & Q.M. & F & \\
\hline Devido à regressão & 3 & 3766,9 & 1255,6 & $14,05^{* *}$ & \\
\hline Erro & 37 & 3395,6 & 89,3 & & \\
\hline \multicolumn{6}{|l|}{$\mathrm{R}^{2}=\overline{0} \overline{4} \overline{4885}$} \\
\hline \multicolumn{6}{|c|}{ ESTIMATIVA DOS PARÂMETROS DA REGRESSĀO $\mathrm{Y}=\mathrm{Y}(\mathrm{W}, \mathrm{N})$. } \\
\hline Coeficiente & Valor & & Erro Padrão & Valor "t" & \\
\hline Constante & 168,99 & & & & \\
\hline Linear do nitrogênio & 0,125 & & 0,028334 & 4,4297 & \\
\hline Quadrático do nitrogênio & $-0,000$ & & 0,0000506 & $-3,4177$ & \\
\hline Linear da água & 0,001 & & 0,00050642 & 3,6989 & \\
\hline
\end{tabular}

** - Significativo ao nivel de $1 \%$ de probabilidade.

* - Significativo ao nível de $5 \%$ de probabilidade.

NS - Não significativo.

A equação de regressão encontrada para estimar o peso médio do fruto (equação 19) é significativa ao nível de $1 \%$ de probabilidade pelo teste de "F", com coeficiente de determinação de 48,85\% (Tabela 9).

$$
P=169+1,26 \cdot 10^{-1} \mathrm{~N}-1,73 \cdot 10^{-4} \mathrm{~N}^{2}+1,87 \cdot 10^{-3} \mathrm{~W}
$$

sendo, $\mathbf{P}$ o peso médio do fruto na colheita $(\mathrm{g})$ 
Pode-se observar na Figura 13 que o efeito dos níveis de irrigação apresentou tendência linear e crescente e o efeito das doses de nitrogênio tendência quadrática para o peso médio do fruto, atingindo de 208,1 g/fruto com 364,2 g de N/árvore e 86401 de água/árvore.

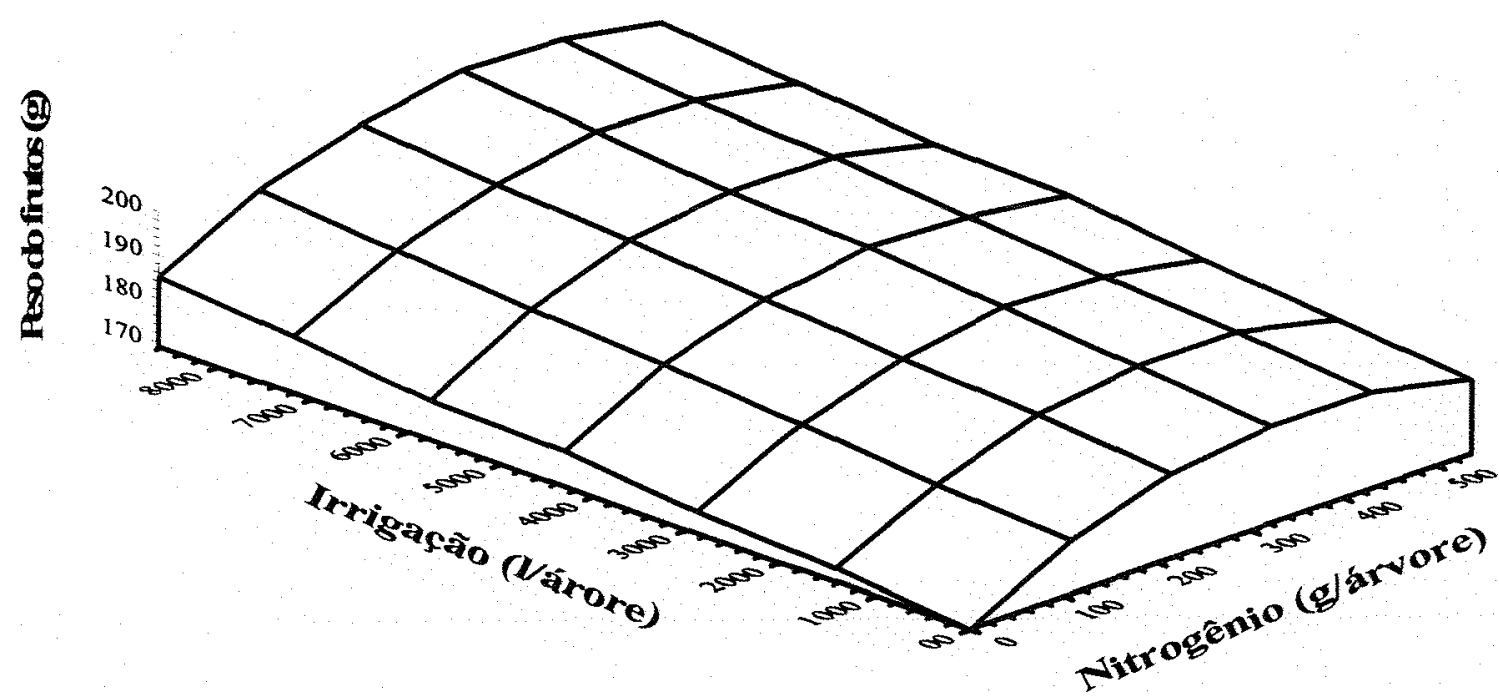

Figura 13. Superfície de resposta para o peso médio de fruto em função da irrigação e adubação nitrogenada.

De janeiro a julho de 1996 a precipitação pluvial acumulada foi de $1144,8 \mathrm{~mm}$, necessitando-se apenas de 19 irrigações. Portanto, as irrigações no período de julho a dezembro de 1995 foram aquelas que diferenciaram o peso médio do fruto entre tratamentos. A adubação nitrogenada foi conduzida mesmo durante os períodos de chuvas, apresentando efeito quadrático para o peso do fruto. 
Guardiola (1992) aponta uma relação inversa entre o número de frutos produzidos por árvore e o peso médio do fruto, com coeficiente de correlação entre $-0,427$ e $-0,666$. No presente trabalho encontrou-se uma relação linear crescente entre número de frutos produzidos e seu peso, com coeficiente de correlação de 0,5541 . Esta relação é dependente da disponibilidade de água e de nitrogênio para as plantas, conforme pode ser observado nas Tabelas 6 e 8, o que contesta a afirmação de Guardiola (1992). Hilgeman (1977) também observou que o número de frutos por árvore não afetou o peso do fruto, no entanto o déficit hidrico em reduziu o peso do fruto.

Observa-se pela comparação da Tabela 6 e Figuras 11 e 12 com a Tabela 8 e Figura 13 que o efeito do nitrogênio é semelhante para o número de frutos e peso médio do fruto. O efeito da irrigação é quadrático para número de frutos e linear crescente para peso do fruto. Orphanos e Eliades (1992) trabalhando com laranja valência em pomares irrigados, encontraram efeito quadrático para nitrogênio e máximo peso do fruto foi obtido com 320 g de N/árvore.

\subsection{Caixas de frutos produzidos por árvore}

$\mathrm{Na}$ Tabela 10 encontram-se os valores médios do número de caixas de frutos produzidos por árvore, em função dos volumes de água de irrigação e das doses de nitrogênio. A maior produção (3,6 caixas/árvore) foi obtida no tratamento $\mathrm{N}_{3} \mathrm{~W}_{4}(322,5 \mathrm{~g}$ 
de $\mathrm{N}$ e 57601 de água por árvore) e a menor (0,50 caixas por árvore) no tratamento $\mathrm{N}_{0} \mathrm{~W}_{0}$ (ausência de adubação nitrogenada e irrigação).

Tabela 10. Número de caixas de frutos $(40,8 \mathrm{~kg}$ de frutos) produzidos por árvore

\begin{tabular}{lccccccrrr}
\hline $\begin{array}{l}\text { Níveis de } \\
\text { nitrogênio } \\
\text { g/árvore }\end{array}$ & $\mathrm{W}_{0}(0)$ & $\mathrm{W}_{1}(1440)$ & $\mathrm{W}_{2}(2880)$ & $\mathrm{W}_{3}(4320)$ & $\mathrm{W}_{4}(5760)$ & $\mathrm{W}_{5}(7200)$ & $\mathrm{W}_{6}(8640)$ & Média \\
\hline $\mathrm{N}_{0}(0)$ & 0,5 & 0,9 & 1,0 & 1,6 & 1,1 & 0,9 & 0,5 & 0,9 \\
$\mathrm{~N}_{1}(107,5)$ & 1,3 & 1,6 & 1,6 & 2,3 & 3,0 & 3,0 & 2,5 & 2,2 \\
$\mathrm{~N}_{2}(215)$ & 1,8 & 1,9 & 2,2 & 3,2 & 3,4 & 2,6 & 2,8 & 2,5 \\
$\mathrm{~N}_{3}(322,5)$ & 2,5 & 2,3 & 2,9 & 3,0 & 3,6 & 3,0 & 1,9 & 2,7 \\
$\mathrm{~N}_{4}(430)$ & 1,8 & 2,9 & 2,5 & 3,1 & 2,9 & 2,4 & 2,4 & 2,6 \\
$\mathrm{~N}_{5}(537,5)$ & 1,5 & 2,5 & 2,2 & 3,1 & 2,9 & 2,4 & 1,8 & 2,4 \\
\hline Média & 1,6 & 2,0 & 2,1 & 2,7 & 2,8 & 2,4 & 2,0 & \\
\hline
\end{tabular}

$\mathrm{Na}$ ausência da irrigação, o maior número de caixa de frutos produzidos por árvore foi obtido com o nível $\mathrm{N}_{3}$ de nitogênio (322,5 g/árvore) e o menor com o $\mathrm{N}_{0}$ (ausência de adubação nitrogenada), respectivamente 2,5 e 0,5 caixas de frutos por árvore. Portanto, a redução na produção é de $80,0 \%$.

$\mathrm{Na}$ ausência da adubação nitrogenada, o maior número de caixas de frutos por árvore foi alcançado no nível de irrigação $\mathrm{W}_{3}$ (4320 l de água/ árvore) e o menor em $\mathrm{W}_{0}$ (sem irrigação) e $\mathrm{W}_{6}$ (8640 l de água/árvore), respectivamente 1,6 e 0,5 caixa de frutos por árvore, representando uma redução de $68,15 \%$..

A análise de variância dos desdobramentos da regressão (Tabela 11) mostrou efeito não significativo para interação entre água e nitrogênio, pelo teste de "F". Utilizou-se o desdobramento quadrático como o de maior ordem, significativo ao nível de $1 \%$ de probabilidade pelo teste de "F". A equação de regressão encontrada para 
estimar o número de caixas de frutos na colheita [equação (20)] é significativa ao nível de $1 \%$ de probabilidade pelo teste de "F", com coeficiente de determinação de $78,14 \%$.

A produção máxima estimada pela equação (20) foi 3,2 caixas por árvore, para o volume de água de irrigação de 5095,6 1/árvore e de nitrogênio de 345,9 g/árvore.

A menor produção estimada foi 0,3 caixas por árvore, na ausência de adubação nitrogenada e irrigação. Em razão dessa diferença de produção (90,62\%), evidencia-se que a água e o nitrogênio são fundamentais para viabilizar a produção de pomares de laranja pêra.

$$
\begin{aligned}
& C X=0,306+1,01 \cdot 10^{-2} \mathrm{~N}-1,46 \cdot 10^{-5} \mathrm{~N}^{2}+4,53 \cdot 10^{-4} \mathrm{~W}-4,47 \cdot 10^{-8} \mathrm{~W}^{2} \\
& \mathrm{R}^{2}=0,7814
\end{aligned}
$$

sendo CX o número de caixas de frutos colhidos por árvore ( 1 caixa $=40,8 \mathrm{~kg}$ de frutos).

O volume de água para maximizar o número de caixas de frutos por árvore (5095,6 l/árvore) difere de apenas de 4,79\% do volume para maximizar o número de frutos por árvore (4851,7 l/árvore) e as doses de nitrogênio para os dois casos foram praticamente as mesmas (345,9 e 345,7 g/árvore). No entanto, o volume de água necessário para maximizar o peso médio do fruto ( 8640 l/árvore) foi maior do que aquele necessário para maximizar a produção de caixas de frutos (5095,6 l/árvore).

A dose de nitrogênio para maximizar o peso do fruto (364,2 g /árvore) foi 5\% maior que a dose necessária para maximizar a produção de caixas de frutos $(345,9$ g/árvore). Bielorai et al. (1984) e Plessis e Koen (1984) trabalhando com três doses de nitrogênio também encontraram relações positivas entre este fator e a produção de frutos. 
Tabela 11. Análise de variância dos tratamentos e seus desdobramentos, da regressão e dos coeficientes da regressão para caixas de frutos produzidos por árvore

\begin{tabular}{|c|c|c|c|c|c|}
\hline \multicolumn{6}{|c|}{ ANÁLISE DE VARIÂNCIA DOS DESDOBRAMENTOS DA REGRESSĀO } \\
\hline Fonte de variação & G.L & S.Q. & Q.M. & $\mathbf{F}$ & $\mathbf{R}^{2}$ \\
\hline Nitrogênio & 5 & 15,184 & 3,036 & 23,9 & \\
\hline Efeito linear & 1 & 7,053 & 7,054 & $55,523 * *$ & 0,46 \\
\hline Efeito Quadrático & 1 & 7,474 & 7,474 & $58,831 * *$ & 0,96 \\
\hline Falta de ajustamento & 3 & 0,657 & 0,218 & $1,869 \mathrm{NS}$ & \\
\hline Água & 6 & 7,110 & 1,184 & $9,327^{* *}$ & \\
\hline Efeito linear & 1 & 1,539 & 1,539 & $12,116^{* *}$ & 0,22 \\
\hline Efeito Quadrático & 1 & 4,333 & 4,334 & $34,114 * *$ & 0,83 \\
\hline Falta de ajustamento & 4 & 1,229 & 0,307 & $2,420 \mathrm{NS}$ & \\
\hline Residuo & 30 & 3,84 & 0,127 & & \\
\hline \multicolumn{6}{|l|}{$\mathrm{CV}=16,05 \%$} \\
\hline \multicolumn{6}{|c|}{ ANÁLISE DE VARIÂNCIA DA REGRESSÃO } \\
\hline Fonte de variação & G.L. & S.Q. & Q.M. & $\mathbf{F}$ & \\
\hline Devido à regressão & 4 & 20,401 & 5,100 & $33,08 * *$ & \\
\hline Erro & 37 & 5,704 & 0,1541 & & \\
\hline \multicolumn{6}{|l|}{$\mathrm{R}^{2}=\overline{0}, \overline{7} \overline{814}$} \\
\hline \multicolumn{6}{|c|}{ ESTIMATIVA DOS PARÂMETROS DA REGRESSÃO $Y=Y(W, N)$} \\
\hline Coeficiente & Valor & & Erro Padrão & Valor "t" & \\
\hline Constante & 0,306 & & & & \\
\hline Linear do nitrogênio & 0,010 & & 0,00117 & 8,579 & \\
\hline Quadrático do nitrogênio & $-0,000$ & & 0,0000021 & $-6,962$ & \\
\hline Linear da água & 0,000 & & 0,0000758 & 5,970 & \\
\hline Quadrático da água & $-0,000$ & $* *$ & 0,000000008434 & $-5,302$ & \\
\hline
\end{tabular}

** - Significativo ao nível de $1 \%$ de probabilidade.

* - Significativo ao nível de $5 \%$ de probabilidade.

NS - Não significativo.

Os coeficientes de correlação estimados para número de caixas de frutos e número de frutos por árvore foi 0,988 e entre número de caixas e peso médio do fruto foi 0,663. Observa-se que o efeito do número de frutos foi mais acentuado na produção de caixas por árvore que o efeito do peso médio do fruto. Isto também pode ser observado, comparando-se as Figuras 11,12 e 13 com as Figuras 14 e 15 (superfície de resposta e curvas de isoprodução, respectivamente). 


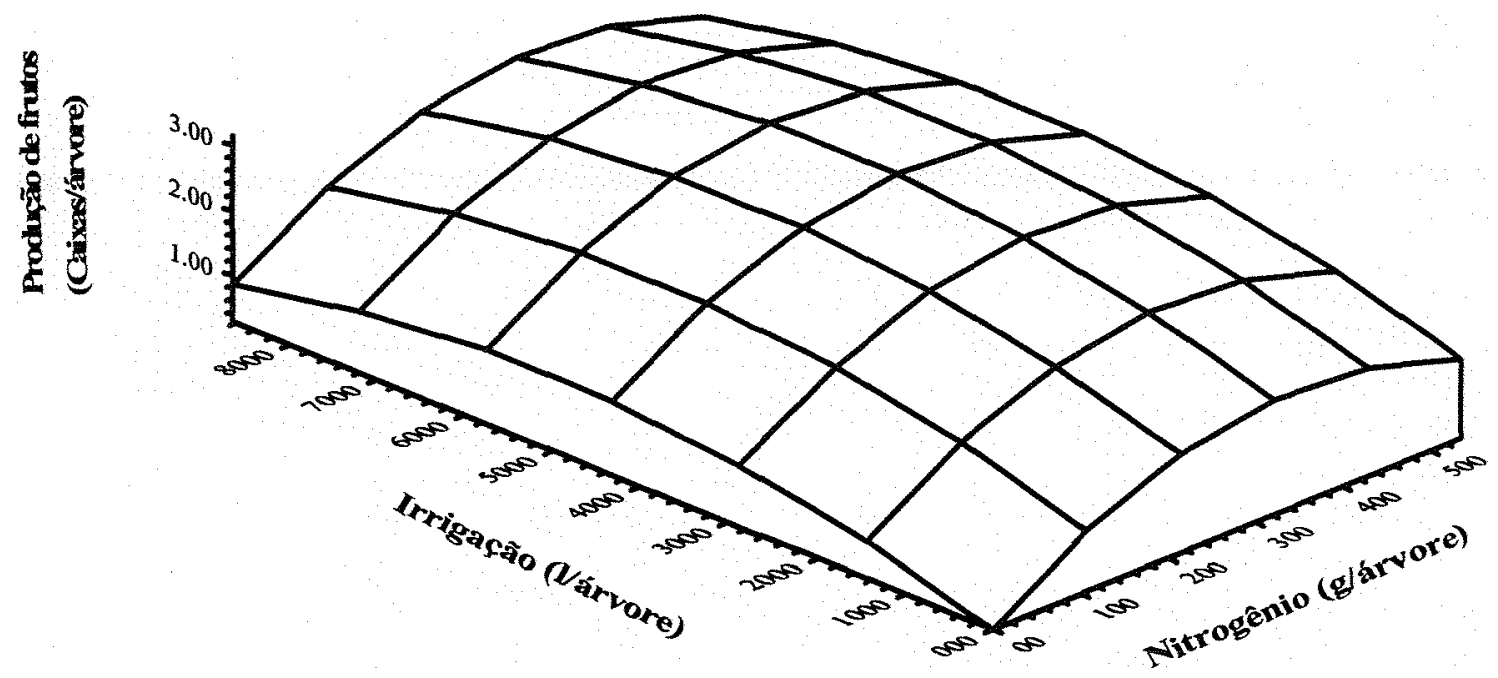

Figura 14. Superfície de resposta para número de caixas de frutos por árvore em função da irrigação e adubação nitrogenada.

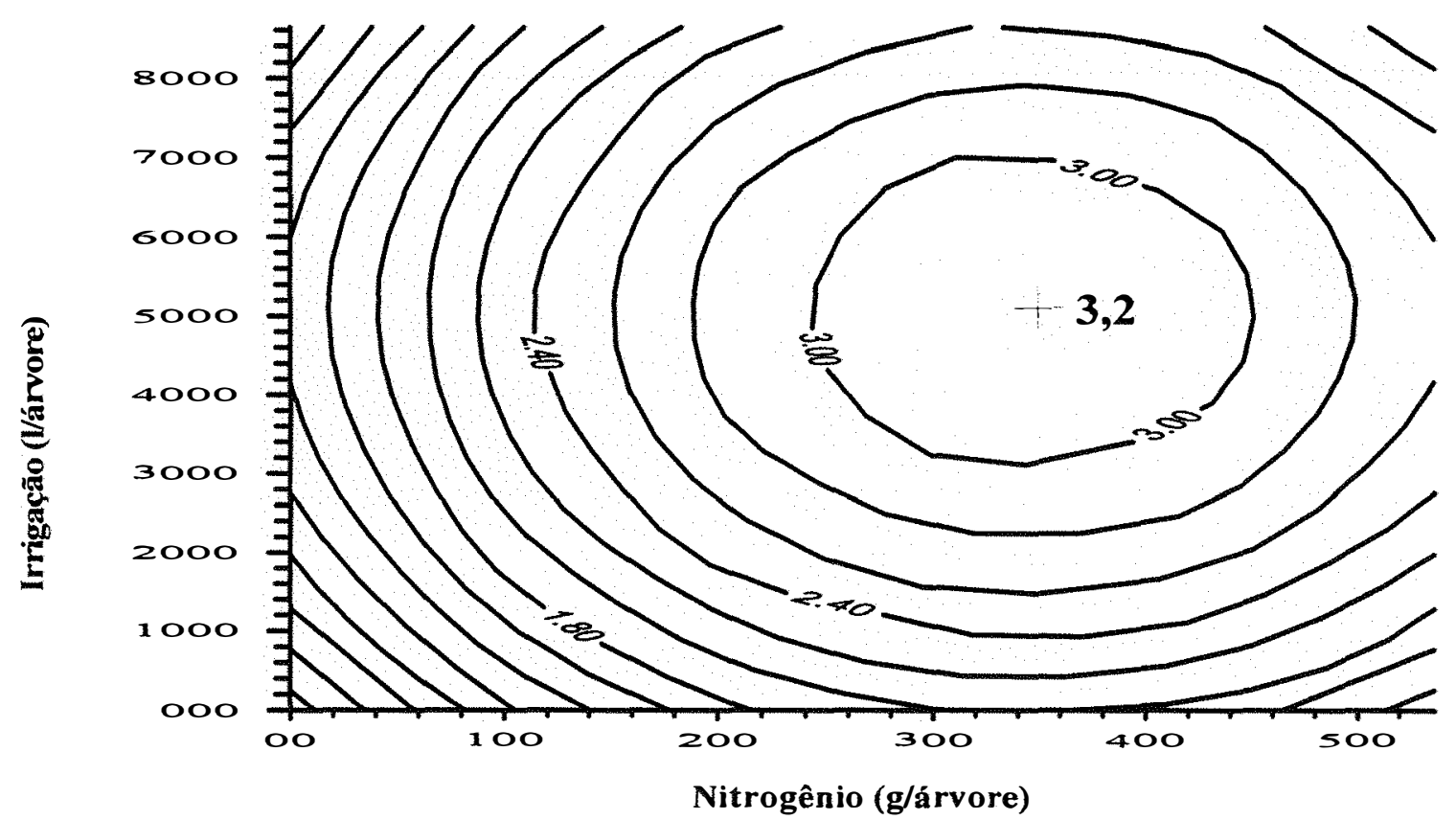

Figura 15. Curvas de isoprodução para número de caixas de frutos por árvore em função da irrigação e adubação nitrogenada. 
A produtividade de laranja é influenciada pelas variáveis climáticas, edáficas, biológicas e de manejo, sendo essas responsáveis por diferenças significativas entre os resultados de produção encontrados na literatura. Neste trabalho foram encontradas produções semelhantes às relatadas por Malavolta et al (1988), que estimou entre $125 \mathrm{a}$ $160 \mathrm{~kg}$ de frutos por árvore com níveis de nitrogênio de até $450 \mathrm{~g} /$ árvore, apesar de o autor não se referir a culturas irrigadas.

Koo (1979) observou que na ausência de irrigação as produções de laranja foram sempre menores, durante os oito anos que conduziu o experimento. Por outro lado, Koo e Reese (1977) destacam que a irrigação é mais importante na fixação dos frutinhos do que na produção de laranja.

Hilgeman (1977) e Parson e Muraro (1991) salientam que o déficit hídrico pode reduzir a produção de laranja devido a queda de frutinhos. Os resultados do presente trabalho indicam que a irrigação aumenta a produção de frutos.

Relativamente aos mercados compradores (indústria, suco fresco ou frutos de mesa) o produtor de laranja pode otimizar o peso médio do fruto ou o número de caixas colhidas por árvore manejando os níveis de água e nitrogênio em função das exigências particulares do mercado. De qualquer forma, o tipo de mercado deve ser conhecido antes do período de florescimento. Somente assim pode-se optar por maximizar a produção física (comercialização de frutos por caixa) ou maximizar o tamanho médio do fruto (comercialização de frutos para mesa). 
A comercialização de frutos para consumo in natura obedece uma classificação por tamanho, tendo mais valor os maiores frutos (Gazzola et al., 1991). Desta forma, frutos para mesa devem receber maiores níveis de água que frutos destinados à indústria.

Observou-se que a uniformidade e concentração da produção devido a irrigação e a adubação nitrogenada permitiram que o ciclo de produção da laranja ocorresse em doze meses, enquanto a laranja pêra sem irrigação tem um ciclo médio de produção de 14 meses para a obtenção de frutos com teor de sólidos solúveis maior que $10 \%$.

A relação comercial entre o produtor de laranja e a indústria segue a lei da oferta e procura, por isso a disponibilidade de laranja no início da safra permite alcançar melhores preços de mercado e encontrar compradores menos exigentes.

Os insumos que causam aumento de produção física de laranja (kg/árvore) nem sempre aumentam o valor comercial do produto (Parsons e Muraro, 1991); assim é o excesso de água disponível para a planta que pode causar aumento de água no suco do fruto, reduzindo o teor de sólidos solúveis.

\subsection{Produção de suco por fruto}

Na Tabela 12 encontram-se os valores médios do volume de suco por fruto $(\mathrm{ml})$, em função dos volumes de água de irrigação e das doses de nitrogênio. O maior volume de suco produzido por fruto foi de $122,5 \mathrm{ml}$ que ocorreu no tratamento $\mathrm{N}_{5} \mathrm{~W}_{1}(537,5 \mathrm{~g}$ de N/árvore e 14401 de água/árvore). A análise de variância do desdobramento da regressão 
(Tabela 13) revelou efeito não significativo para interação entre água e nitrogênio. Apenas o efeito linear para nitrogênio foi significativo ao nível de $5 \%$ de probabilidade.

Tabela 12. Valores médios do volume de suco produzido por fruto (ml)

\begin{tabular}{lllllllll}
\hline $\begin{array}{l}\text { Níveis de } \\
\text { nitrogênio } \\
\text { g/árvore }\end{array}$ & $\mathrm{W}_{0}(0)$ & $\mathrm{W}_{1}(1440)$ & $\mathrm{W}_{2}(2880)$ & $\mathrm{W}_{3}(4320)$ & $\mathrm{W}_{4}(5760)$ & $\mathrm{W}_{5}(7200)$ & $\mathrm{W}_{6}(8640)$ & Média \\
\hline $\mathrm{N}_{0}(0)$ & 87,5 & 93,7 & 98,7 & 103 & 105,6 & 108,7 & 86,2 & 97,6 \\
$\mathrm{~N}_{1}(107,5)$ & 94,4 & 101,0 & 95,6 & 90,6 & 109,0 & 114,3 & 104,4 & 101,3 \\
$\mathrm{~N}_{2}(215)$ & 107,5 & 103,7 & 105 & 90,6 & 111,9 & 110,0 & 116,5 & 106,5 \\
$\mathrm{~N}_{3}(322,5)$ & 100,0 & 111,8 & 101,2 & 114,4 & 111,2 & 108,0 & 108,7 & 107,9 \\
$\mathrm{~N}_{4}(430)$ & 103,3 & 121,9 & 102,5 & 110,6 & 101,9 & 103,7 & 113,7 & 108,2 \\
$\mathrm{~N}_{5}(537,5)$ & 113,1 & 122,5 & 96,2 & 111,9 & 113,7 & 116,9 & 110,0 & 112,0 \\
\hline Média & 100,9 & 109,1 & 99,8 & 103,5 & 108,8 & 110,2 & 106,5 & \\
\hline
\end{tabular}

Altos níveis de nitrogênio e irrigação, segundo Koo e Reese (1977), podem ser a causa da maior quantidade de frutos verdes na época da colheita. Nesse trabalho não foi encontrada relação entre níveis de irrigação e volume de suco por fruto, possivelmente devido a ocorrência de chuvas no período de enchimento dos frutos. Entretanto os níveis de nitrogênio proporcionam efeito linear crescente.

A equação de regressão encontrada para estimar o volume de suco por fruto (equação 21 ) é significativa ao nível de $1 \%$ de probabilidade pelo teste de "F", com coeficiente de determinação de $26,25 \%$, sendo o parâmetro linear para efeito de nitrogênio também significativo a 1\% de probabilidade (Tabela 13).

$$
\mathrm{SF}=99,86+0,025 \mathrm{~N},\left(\mathrm{R}^{2}=0,2625\right)
$$

sendo SF o volume de suco extraído por fruto na colheita $(\mathrm{ml})$; 
Tabela 13. Análise de variância dos tratamentos e seus desdobramentos, da regressão e dos coeficientes da regressão para volume de suco produzido por fruto.

\begin{tabular}{|c|c|c|c|c|c|}
\hline \multicolumn{6}{|c|}{ ANÁLISE DE VARIÂNCIA DOS DESDOBRAMENTOS DA REGRESSÃO } \\
\hline Fonte de variação & G.L & S.Q. & Q.M. & $\bar{F}$ & $\mathbf{R}^{2}$ \\
\hline Nitrogênio & 5 & 953,6 & 190,7 & $3,611 * *$ & \\
\hline Efeito linear & 1 & 887,6 & 887,6 & $16,8 * *$ & 0,93 \\
\hline Efeito Quadrático & 1 & 28,9 & 28,9 & $0,548 \mathrm{NS}$ & 0,96 \\
\hline Falta de ajustamento & 3 & 37,1 & 12,4 & $0,230 \mathrm{NS}$ & \\
\hline Água & 6 & 626,7 & 104,4 & 1,978 NS & \\
\hline Efeito linear & 1 & 170,4 & 170,4 & $3,220 \mathrm{NS}$ & \\
\hline Efeito Quadrático & 1 & 0,5 & 0,5 & $0,090 \mathrm{NS}$ & \\
\hline Falta de ajustamento & 4 & 455,83 & 113,95 & $2,150 \mathrm{NS}$ & \\
\hline Resíduo & 30 & 1584,3 & $-52,8$ & & \\
\hline
\end{tabular}

\begin{tabular}{lllll}
\hline \multicolumn{5}{c}{ ANÁLISE DE VARIÂNCIA DA REGRESSÃO } \\
\hline Fonte de variação & G.L. & S.Q. & Q.M. & F \\
\hline Devido à regressão & 1 & 887,6 & 887,6 & $15,590^{* *}$ \\
Erro & 37 & 2277,06 & 56,9 & \\
\hline
\end{tabular}

$\mathrm{R}^{2}=\overline{0}, \overline{2} \overline{2} 2 \overline{4}$

\begin{tabular}{|c|c|c|c|}
\hline \multicolumn{4}{|c|}{ ESTIMATIVA DOS PARÂMETROS DA REGRESSÃO Y=Y(W,N) } \\
\hline Coeficiente & Valor & Erro Padrão & Valor "t" \\
\hline Constante & $98,86 * *$ & & \\
\hline Linear do nitrogênio & $0,025 * *$ & 0,00634 & $3,949 * *$ \\
\hline
\end{tabular}

** - Significativo ao nível de $1 \%$ de probabilidade.

* - Significativo ao nivel de $5 \%$ de probabilidade.

NS - Não significativo.

O volume mínimo de suco por fruto estimado foi $99,86 \mathrm{ml}$, significando que para cada unidade de nitrogênio aplicado foi acrescentado $0,025 \mathrm{ml}$ de suco por fruto (equação 21).

Além das chuvas regulares ocorridas durante a fase de enchimento dos frutos, outro fator que contribuiu para a uniformização do volume de suco dos frutos nos diferentes níveis de irrigação, foi o déficit hídrico imposto na fase de maturação para induzir a floração da próxima safra. Neste caso, deve ter ocorrido translocação do suco dos frutos para as funções vitais da planta, conforme destacam Cohen e Goell (1984). 
O fato do efeito das doses de nitrogênio sobre o volume de suco por fruto ter sido significativo somente para o modelo linear, pode ser justificado pela lixiviação do excesso de nitrogênio no solo pelas chuvas abundantes que ocorreram no segundo semestre de condução do experimento.

Haag et al (1993) aplicando $1215 \mathrm{~g}$ de N/árvore/ano, sem irrigação, encontraram valores de volume de suco por fruto de laranja pêra de 70,80 e $50 \mathrm{ml}$ para frutos com 6 , 9 e 11 meses de idade. $\mathrm{O}$ volume de $50 \mathrm{ml}$ aos 11 meses é menor que os encontrados para os níveis $\mathrm{N}_{0} \mathrm{~W}_{0}$ deste trabalho. $\mathrm{O}$ maior volume suco $(122,5 \mathrm{ml})$ foi observado no tratamento $\mathrm{N}_{5} \mathrm{~W}_{1}$ (537,5 g de N/árvore e $1440 \mathrm{l}$ de água /árvore), que corresponde a 1,53 vezes o maior valor encontrado por .Haag et al (1993).

A redução do volume de suco por fruto entre o $9^{\circ}$ e o $11^{\circ}$ mês de idade dos frutos encontrado por Haag et al. (1993) provavelmente se deve ao fato de a cultura ter sido conduzida sem irrigação, o que levou as plantas a drenarem água dos frutos para atender a demanda fisiológica, conforme citam Cohen e Goell (1984).

A produção de grandes volumes de suco por fruto pode ser interessante quando as laranjas são destinadas para ao consumo in natura, pois este mercado exige que a laranja tenha suco e seja doce. Também é de interesse ao mercado de suco fresco, onde o consumidor exige que seja servido o suco integral extraído da laranja na sua presença.

Frutas cítricas para consumo in natura devem ter muito suco com baixa acidez e alto teor de açúcares. Essas são as características consideradas adequadas para o mercado consumidor brasileiro. No entanto, as características de paladar podem variar entre as 
região consumidoras. De qualquer forma, é necessário que os frutos sejam grandes, túrgidos, com coloração de casca amarelada e sem defeitos de casca.

Frutas cítricas para o consumo na forma de suco fresco devem ter abundância de suco, mesmo que os sólidos solúveis sejam diluídos, pois a expectativa do consumidor é de estar comprando suco. Logo, quanto mais suco, mais adequado será o fruto para este mercado.

4.6. Volume de suco produzido por árvore

Na Tabela 14 encontram-se os valores médios do volume de suco produzido por árvore, em função dos volumes de água de irrigação e das doses de nitrogênio. Os maiores valores (76,7 e 75,3 l de suco/árvore) foram obtidos respectivamente nos tratamentos $\mathrm{N}_{3} \mathrm{~W}_{4}\left(322,5 \mathrm{~g}\right.$ de N/árvore e 57601 de água/árvore) e $\mathrm{N}_{3} \mathrm{~W}_{3}(322,5 \mathrm{~g}$ de N/árvore e 57601 de água/árvore). Os menores valores (10,3 e 11,3 l de suco/árvore), ocorreram nos tratamentos $\mathrm{N}_{0} \mathrm{~W}_{6}$ e $\mathrm{N}_{0} \mathrm{~W}_{0}$. A diferença relativa entre os tratamentos $\mathrm{N}_{3} \mathrm{~W}_{4}$ e $\mathrm{N}_{0} \mathrm{~W}_{6}$ foi $86,6 \%$ e entre $\mathrm{N}_{3} \mathrm{~W}_{4}$ e $\mathrm{N}_{0} \mathrm{~W}_{0}$ foi $85,3 \%$, evidenciando que, na ausência de nitrogênio o excesso e o déficit de água são prejudiciais à produção de suco.

A análise de variância dos desdobramentos da regressão (Tabela 14) revelou efeito não significativo para interação entre água e nitrogênio, pelo teste de "F". Considerou-se que o desdobramento quadrático foi o de maior ordem, significativo ao nível de $1 \%$ de probabilidade pelo teste de " $\mathrm{F}$. 
Tabela 14. Volume de suco produzido (1/árvore)

\begin{tabular}{lllllllll}
\hline $\begin{array}{l}\text { Níveis de } \\
\text { nitrogênio }\end{array}$ & & \multicolumn{7}{c}{ Volumes de irrigação (Várvore) } \\
g/árvore & $\mathrm{W}_{0}(0)$ & $\mathrm{W}_{1}(1440)$ & $\mathrm{W}_{2}(2880)$ & $\mathrm{W}_{3}(4320)$ & $\mathrm{W}_{4}(5760)$ & $\mathrm{W}_{5}(7200)$ & $\mathrm{W}_{6}(8640)$ & Média \\
\hline $\mathrm{N}_{0}(0)$ & 11,3 & 18,8 & 23,1 & 37,8 & 26,5 & 20,5 & 10,3 & 21,2 \\
$\mathrm{~N}_{1}(107,5)$ & 28,8 & 36,5 & 36,1 & 46,7 & 69,1 & 67,1 & 56,7 & 48,7 \\
$\mathrm{~N}_{2}(215)$ & 42,8 & 40,8 & 47,3 & 59,3 & 73,2 & 54,8 & 60,9 & 54,1 \\
$\mathrm{~N}_{3}(322,5)$ & 56,7 & 53,4 & 60,8 & 75,3 & 76,7 & 65,0 & 38,7 & 61,0 \\
$\mathrm{~N}_{4}(430)$ & 40,0 & 70,6 & 53,2 & 73,0 & 66,0 & 54,0 & 54,5 & 58,7 \\
$\mathrm{~N}_{5}(537,5)$ & 36,5 & 60,9 & 46,8 & 69,0 & 69,7 & 56,9 & 40,5 & 54,3 \\
\hline Média & 36,0 & 46,8 & 44,5 & 60,2 & 63,5 & 53,1 & 43,6 & \\
\hline
\end{tabular}

A equação de regressão para estimativa do volume de suco produzido por árvore (equação 22) é significativa ao nível de $1 \%$ de probabilidade pelo teste de "F", com coeficiente de determinação de $70,84 \%$, sendo os parâmetros da equação também significativos a $1 \%$ de probabilidade (Tabela 15 ).

$$
\begin{aligned}
& \mathrm{VS}=8,14+2,12 \cdot 10^{-1} \mathrm{~N}-2,94 \cdot 10^{-4} \mathrm{~N}^{2}+9,62 \cdot 10^{-3} \mathrm{~W}-9,58 \cdot 10^{-7} \cdot \mathrm{W}^{2} \\
& \mathrm{R}^{2}=0,7084
\end{aligned}
$$

sendo VS o volume de suco, por árvore (l).

O volume máximo de suco produzido por árvore estimado pela equação (19) foi 70,5 litros, para o volume de irrigação de 5020,0 1/árvore e dose de nitrogênio de 360,5 g/árvore. O menor volume de suco por árvore foi de 8,14 litros, estimado na ausência da irrigação complementar e da adubação nitrogenada. Neste caso, a diferença relativa entre os valores estimados foi de $88,5 \%$. 
Tabela 15. Análise de variância dos tratamentos e seus desdobramentos, da regressão e dos coeficientes da regressão para volume de suco produzido por árvore

\begin{tabular}{|c|c|c|c|c|c|}
\hline \multicolumn{6}{|c|}{ ANÁLISE DE VARIÂNCIA DOS DESDOBRAMENTOS DA REGRESSĀO } \\
\hline Fonte de variação & G.L & S.Q. & Q.M. & $\mathbf{F}$ & $\mathbf{R}^{2}$ \\
\hline Nitrogênio & 5 & 7439,9 & 1487,9 & $19,047^{* *}$ & \\
\hline Efeito linear & 1 & 4105,1 & 4105,1 & $52,548 * *$ & 0,55 \\
\hline Efeito Quadrático & 1 & 3012,898 & 3012,896 & $38,567^{* *}$ & 0,96 \\
\hline Falta de ajustamento & 3 & 321,95 & 107,3 & $1,37 \mathrm{NS}$ & \\
\hline Água & 6 & 3431,9 & 572,0 & $7,322 * *$ & \\
\hline Efeito linear & 1 & 630,5 & 630,5 & $8,071 * *$ & 0,18 \\
\hline Efeito Quadrático & 1 & 1939,1 & 1989,1 & $25,461^{* *}$ & 0,76 \\
\hline Falta de ajustamento & 4 & 500,8 & 125,2 & $1,602 \mathrm{NS}$ & \\
\hline Resíduo & 30 & & & & \\
\hline \multicolumn{6}{|l|}{$\mathrm{CV}=17,8 \%$} \\
\hline \multicolumn{6}{|c|}{ ANÁLISE DE VARIÂNCIA DA REGRESSÃO } \\
\hline Fonte de variação & G.L. & S.Q. & Q.M. & $\mathbf{F}$ & \\
\hline Devido à regressão & 4 & 9737,6 & 2434,4 & $25,900 * *$ & \\
\hline Erro & 37 & 3477,9 & 94,0 & & \\
\hline $\mathrm{R}^{2}=0$ & & & & & \\
\hline \multicolumn{6}{|c|}{ ESTIMATIVA DOS PARÂMETROS DA REGRESSÃO $Y=Y(W, N)$} \\
\hline Coeficiente & Valor & & Erro Padrão & Valor "t" & \\
\hline Constante & 8,144 & & & & \\
\hline Linear do nitrogênio & 0,212 & & 0,0290 & 7,287 & \\
\hline Quadrático do nitrogênio & $-0,000$ & & 0,0000519 & $-5,661$ & \\
\hline Linear da água & 0,009 & & 0,00187 & 5,137 & \\
\hline Quadrático da água & $-0,000$ & & 0,0000000208 & $-4,600$ & \\
\hline
\end{tabular}

** - Significativo ao nível de $1 \%$ de probabilidade.

* - Significativo ao nivel de $5 \%$ de probabilidade.

NS - Não significativo.

Observando-se as Figuras 16 e 17 e comparando-as com as Figuras 11 e 12, verifica-se que o volume de suco por árvore foi mais influenciado pelo número de frutos produzidos por árvore que pelo volume de suco produzido por fruto.

Os coeficientes de correlação entre o volume de suco produzido por árvore, o volume de suco por fruto e o número de frutos por árvore foram respectivamente 0,6131 e 0,9772, o que evidencia a importância do número de frutos para o volume de suco produzido por árvore. 


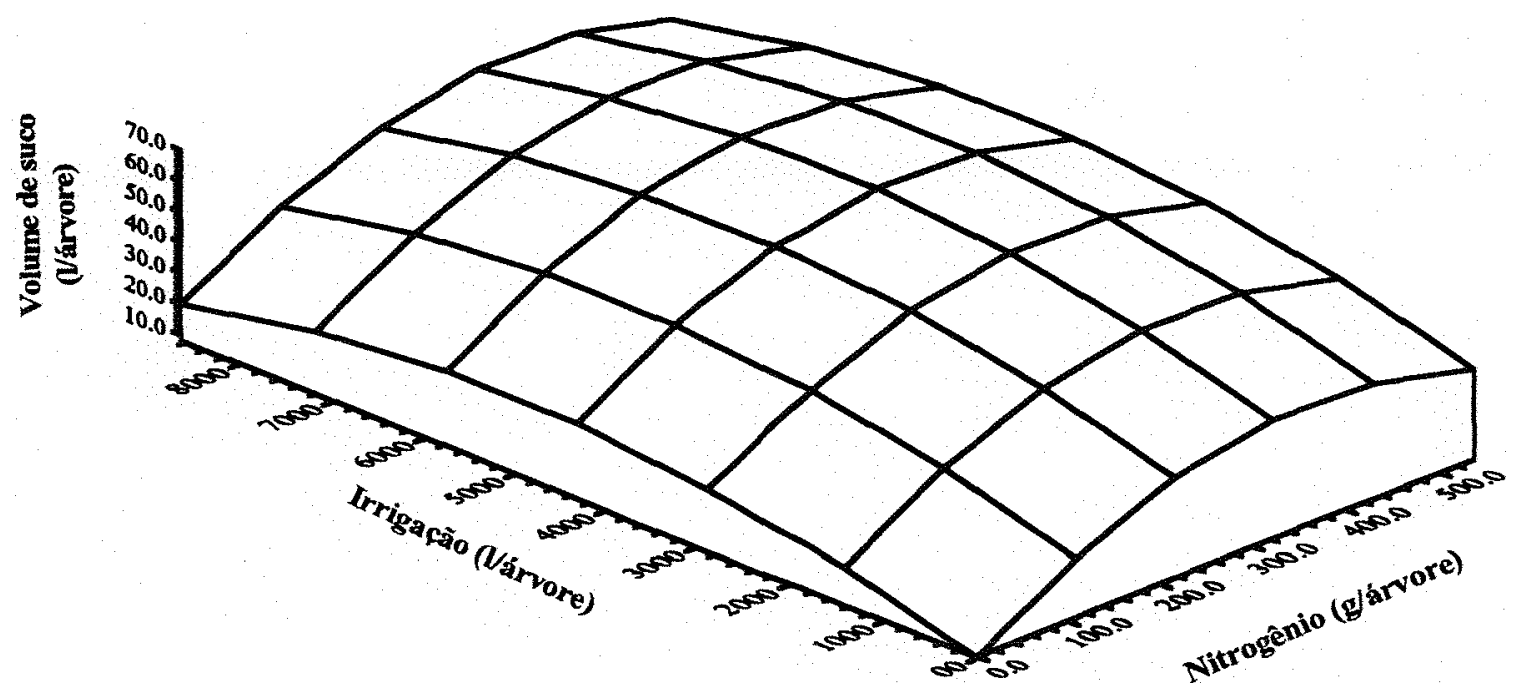

Figura 16. Superficie de resposta para volume de suco produzido por árvore em função da irrigação e adubação nitrogenada

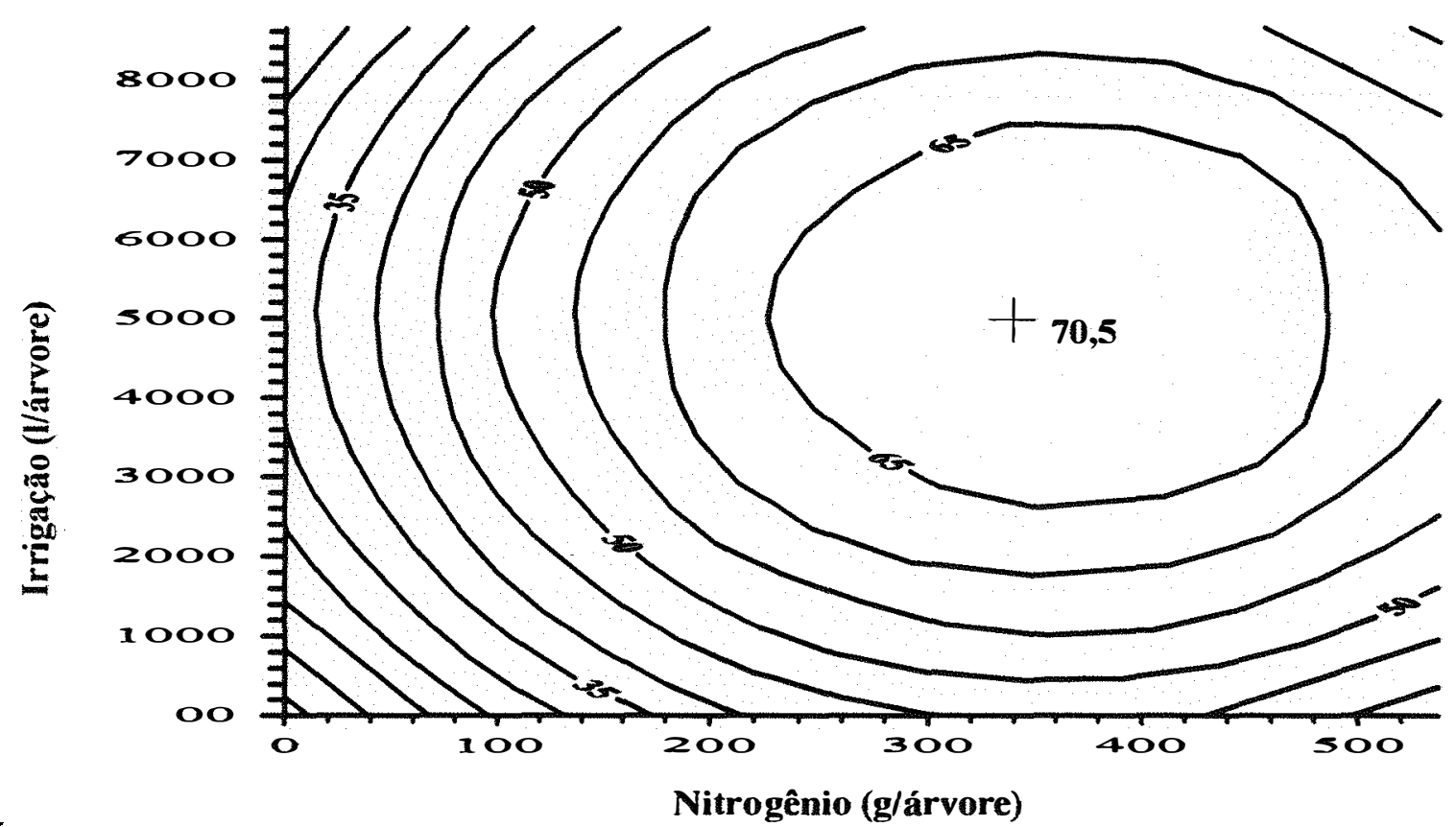

Figura 17. Curvas de isoprodução para volume de suco produzido por árvore em função da irrigação e adubação nitrogenada 
O volume de suco por árvore é um parâmetro relevante na comercialização de frutos in natura e para extração de suco fresco, pois os compradores de frutas para estes mercados freqüentemente têm o hábito de comprar todo o pomar para comercializá-lo ao longo de um período previamente estipulado. Nesses casos, o produtor deve considerar não só o volume de suco produzido por fruto, que é de interesse do comprador, mas também volume de suco produzido por árvore.

4.7. Sólidos solúveis produzidos por fruto (brix)

Na Tabela 16 encontram-se os valores médios do teor de sólidos solúveis dos frutos (brix), em função dos volumes de água de irrigação e das doses de nitrogênio. O tratamento $\mathrm{N}_{2} \mathrm{~W}_{5}$ proporcionou o maior valor $(12,5 \%)$ e o tratamentos $\mathrm{N}_{3} \mathrm{~W}_{0}$ o menor $(9,0 \%)$. Em média, os menores valores de brix foram obtidos com dose de nitrogênio igual ou superior a $430 \mathrm{~g} /$ árvore. A análise de regressão revelou que ocorreu efeito significativo apenas para nitrogênio, com ajustamento linear, a 1\% de probabilidade pelo teste de "F" (Tabela 17).

Tabela 16. Sólidos solúveis produzidos por fruto (\%).

\begin{tabular}{lrrrrrrrr}
\hline $\begin{array}{l}\text { Niveis de } \\
\text { nitrogênio }\end{array}$ & \multicolumn{7}{c}{ Volumes de irrigação (l/árvore) } \\
\cline { 2 - 9 } (g/árvore) & $\mathrm{W}_{0}(0)$ & $\mathrm{W}_{1}(1440)$ & $\mathrm{W}_{2}(2880)$ & $\mathrm{W}_{3}(4320)$ & $\mathrm{W}_{4}(5760)$ & $\mathrm{W}_{5}(7200)$ & $\mathrm{W}_{6}(8640)$ & Média \\
\hline $\mathrm{N}_{0}(0)$ & 10,00 & 12,00 & 9,00 & 9,50 & 12,00 & 11,00 & 10,00 & 10,5 \\
$\mathrm{~N}_{1}(107,5)$ & 11,50 & 10,50 & 10,50 & 10,00 & 10,50 & 11,00 & 10,00 & 10,6 \\
$\mathrm{~N}_{2}(215)$ & 11,50 & 10,00 & 10,50 & 10,00 & 9,50 & 12,50 & 11,00 & 10,7 \\
$\mathrm{~N}_{3}(322,5)$ & 9,00 & 10,00 & 9,50 & 12,00 & 11,00 & 9,50 & 11,50 & 10,4 \\
$\mathrm{~N}_{4}(430)$ & 9,00 & 9,50 & 9,50 & 9,50 & 10,00 & 9,50 & 9,50 & 9,5 \\
$\mathrm{~N}_{5}(537,5)$ & 9,50 & 9,00 & 9,50 & 9,50 & 10,00 & 9,50 & 9,00 & 9,4 \\
\hline Média & 10,1 & 10,2 & 9,8 & 10,1 & 10,5 & 10,5 & 10,2 & \\
\hline
\end{tabular}


Tabela 17. Análise de variância dos tratamentos e seus desdobramentos, da regressão e dos coeficientes da regressão para teor de sólidos solúveis contidos nos fruto

\begin{tabular}{|c|c|c|c|c|c|}
\hline \multicolumn{6}{|c|}{ NAÁLISE DE VARIÂNCIA DOS DESDOBRAMENTOS DA REGRESSÃO } \\
\hline Fonte de variação & G.L & S.Q. & Q.M. & $\mathbf{F}$ & $\mathbf{R}^{2}$ \\
\hline Nitrogênio & 5 & 11,19 & 2,24 & $2,888 *$ & \\
\hline Efeito linear & 1 & 7,97 & 7,97 & $10,281 *$ & 0,71 \\
\hline Efeito Quadrático & 1 & 1,85 & 1,85 & $2,389 \mathrm{NS}$ & \\
\hline Falta de ajustamento & 3 & 1,37 & 0,45 & $0,589 \mathrm{NS}$ & \\
\hline Água & 6 & 2,45 & 0,40 & $0,527 \mathrm{NS}$ & \\
\hline Efeito linear & 1 & 0,59 & 0,59 & $0,768 \mathrm{NS}$ & \\
\hline Efeito Quadrático & 1 & 0,00198 & 0,00198 & $0.03 \mathrm{NS}$ & \\
\hline Falta de ajustamento & 4 & 1,855 & 0,463 & $0,598 \mathrm{NS}$ & \\
\hline Resíduo & 30 & 23,26 & 0,78 & & \\
\hline \multicolumn{6}{|l|}{$\mathrm{CV}=8,65 \%$} \\
\hline \multicolumn{6}{|c|}{ ANÁLISE DE VARIÂNCIA DA REGRESSĀO } \\
\hline Fonte de variação & G.L. & S.Q. & Q.M. & $\mathbf{F}$ & \\
\hline Devido à regressão & 1 & 7,97 & 7,97 & $11,02 * *$ & \\
\hline Erro & 40 & 28,9 & 0,72 & & \\
\hline \multicolumn{6}{|c|}{$\mathrm{R}^{2} \equiv \overline{0} \overline{19} \overline{6}$} \\
\hline \multicolumn{6}{|c|}{ ESTIMATIVA DOS PARÂMETROS DA REGRESSÃO $Y=Y(W, N)$, } \\
\hline Coeficiente & Valor & & Erro Padrão & Valor "t" & \\
\hline Constante & 10,82 & & & & \\
\hline Linear do nitrogênio & $-2,3710^{-3 * *}$ & & 0,715 & $-3,33$ & \\
\hline
\end{tabular}

A equação de regressão para descrever a tendência de variação do teor de sólidos solúveis nos frutos em função das doses de nitrogênio (equação 23) foi significativa ao nível de $1 \%$ de probabilidade pelo teste de "F", apesar do baixo coeficiente de determinação (19,6\%), conforme apresenta-se na Tabela 17.

$$
\mathrm{B}=10,8-2,37 \cdot 10^{-3} \mathrm{~N},\left(\mathrm{R}^{2}=0,196\right)
$$

em que B é a percentagem de sólidos solúveis por fruto (brix).

Observa-se pela equação (23) que o maior teor de sólidos solúveis estimado é de $10,8 \%$ e, para cada unidade e nitrogênio aplicado, o valor do brix reduz de $2,37.10^{-3}$ unidades. 
$\mathrm{Na}$ Tabela 16 pode-se observar que as menores quantidades de sólidos solúveis por fruto ocorreram nos tratamentos de nitrogênio $N_{4}$ e $N_{5}$ (430 e 537,5 g/árvore), o que demonstra uma relação inversa entre os teores de sólido solúvel por fruto e os níveis de nitrogênio.

O teor de sólidos solúveis em frutos de citrus é depende do "stress" hídrico sofrido pela planta em períodos próximos da colheita, quando os frutos já se encontram em fase de maturação (Koo,1980, Hilgeman, 1977 e Coell, 1984). No presente trabalho, houve stress hídrico neste período em todos os tratamentos proporcionando efeito não significativo da irrigação complementar. Contudo, o teor de sólidos solúveis nos frutos foi influenciado significativamente pelos níveis de nitrogênio.

Mungomery et al.(1978) não encontraram diferença significativa nos teores de sólidos solúveis produzidos por fruto entre aplicações de 450 e 1350 g de N/árvore, em culturas irrigadas. Sharples (1969) também não observou diferença quando aplicou 90 a $400 \mathrm{~g}$ de N/árvore, contudo, obteve menores teores de sólidos solúveis quando as doses de nitrogênio foram inferiores à 90 g/árvore. O efeito significativo do nitrogênio encontrado neste trabalho, possivelmente tenha ocorrido em razão do fracionamento semanal das doses, o que pode ter aumentado a eficiência de utilização pela planta.

Bielorai et al (1984), trabalhando em solo arenoso, não encontraram diferenças significativas nos teores de sólidos solúveis dos frutos para aplicações de 240, 408 e 743 g de N/árvore. Os autores justificam estes resultados pela condição favorável à lixiviação do nitrogênio em solo arenoso. 


\subsection{Sólidos solúveis produzidos por árvore}

Na Tabela 18 encontram-se os valores médios da quantidade de sólidos solúveis produzidos por árvore em função dos volumes de água de irrigação e das doses de nitrogênio. $\mathrm{O}$ maior valor $(9,03 \mathrm{~kg} /$ árvore $)$ foi obtido no tratamento $\mathrm{N}_{3} \mathrm{~W}_{3}$ e o menor $(1,03$ $\mathrm{kg}$ /árvore) foi obtido em $\mathrm{N}_{0} \mathrm{~W}_{6}$. A análise de variância para regressão mostrou efeito não significativo para interação entre os fatores, pelo teste de "F". Considerou-se o efeito quadrático o de maior grau, significativo ao nível de $1 \%$ de probabilidade pelo teste de "F", para água e nitrogênio (Tabela19).

A equação de regressão encontrada para estimar a produção de sólidos solúveis por árvore (equação 23) é significativa ao nível de 1\% de probabilidade pelo teste de "F", com um coeficiente de determinação de $67,03 \%$, sendo os parâmetros da equação também significativos a $1 \%$ de probabilidade (Tabela 19 ).

Tabela 18. Sólidos solúveis produzidos por árvore $(\mathrm{kg})$.

\begin{tabular}{|c|c|c|c|c|c|c|c|c|}
\hline \multirow{2}{*}{$\begin{array}{l}\text { Níveis de } \\
\text { nitrogênio } \\
\text { (g/árvore) }\end{array}$} & \multicolumn{8}{|c|}{ Volumes de irrigação (l/árvore) } \\
\hline & $\mathrm{W}_{0}(0)$ & $\mathrm{W}_{1}(1440)$ & $\mathrm{W}_{2}(2880)$ & $\mathrm{W}_{3}(4320)$ & $\mathrm{W}_{4}(5760)$ & $\mathrm{W}_{5}(7200)$ & $\mathrm{W}_{6}(8640)$ & Média \\
\hline $\mathrm{N}_{0}(0)$ & 1,13 & 2,26 & 2,08 & 3,59 & 3,18 & 2,26 & 1,03 & $\overline{2,2}$ \\
\hline$N_{1}(107,5)$ & 3,31 & 3,83 & 3,79 & 4,67 & 7,26 & 7,38 & 5,67 & 5,1 \\
\hline $\mathrm{N}_{2}(215)$ & 4,92 & 4,08 & 4,96 & 5,93 & 6,95 & 6,85 & 6,70 & 5,8 \\
\hline $\mathrm{N}_{3}(322,5)$ & 5,10 & 5,34 & 5,78 & 9,03 & 8,44 & 6,18 & 4,45 & 6,3 \\
\hline $\mathrm{N}_{4}(430)$ & 3,60 & 6,71 & 5,05 & 6,93 & 6,60 & 5,13 & 5,17 & 5,6 \\
\hline $\mathrm{N}_{5}(537,5)$ & 3,47 & 5,48 & 4,44 & 6,56 & 6,97 & 5,41 & 3,64 & 5,1 \\
\hline Média & 3,6 & 4,6 & 4,4 & 6,1 & 6,6 & 5,5 & 4,4 & \\
\hline
\end{tabular}


Tabela 19. Análise de variância dos tratamentos e seus desdobramentos, da regressão e dos coeficientes da regressão para sólidos solúveis produzidos por árvore.

\begin{tabular}{|c|c|c|c|c|c|}
\hline \multicolumn{6}{|c|}{ ANÁLISE DE VARIÂNCIA DOS DESDOBRAMENTOS DA REGRESSÃO } \\
\hline Fonte de variação & G.L & S.Q. & Q.M. & $\mathbf{F}$ & $\mathbf{R}^{2}$ \\
\hline Nitrogênio & 5 & 73,43 & 14,69 & $16,463 * *$ & \\
\hline Efeito linear & 1 & 24,47 & 24,47 & $30,795 * *$ & 0,37 \\
\hline Efeito Quadrático & 1 & 41,61 & 41,61 & $46,664 * *$ & 0,94 \\
\hline Falta de ajustamento & 3 & 4,344 & 1,08 & $1,21 \mathrm{NS}$ & \\
\hline Água & 6 & 41,12 & 6,85 & $7,682 * *$ & \\
\hline Efeito linear & 1 & 9,40 & 9,40 & $10,540 * *$ & 0,23 \\
\hline Efeito Quadrático & 1 & 20,78 & 20,78 & $23,297 * *$ & \\
\hline Falta de ajustamento & 4 & 10,93 & 2,73 & $3,07 *$ & \\
\hline Resíduo & 30 & & & & \\
\hline \multicolumn{6}{|l|}{$\mathrm{CV}=18, \overline{8} \%$} \\
\hline \multicolumn{6}{|c|}{ ANÁLISE DE VARIÂNCIA DA REGRESSĀO } \\
\hline Fonte de variação & G.L. & S.Q. & Q.M. & $\mathbf{F}$ & \\
\hline Devido à regressão & 4 & 99,26 & 24,81 & $21,84 * *$ & \\
\hline Erro & 37 & 42,04 & 1,14 & & \\
\hline \multicolumn{6}{|l|}{$\mathrm{R}^{2}=0,6703$} \\
\hline \multicolumn{6}{|c|}{ ESTIMATIVA DOS PARÅMETROS DA REGRESSÃO $Y=Y(W, N)$} \\
\hline Coeficiente & Valor & & Erro Padrão & Valor "t" & \\
\hline Constante & 0,792 & & & & \\
\hline Linear do nitrogênio & 0,022 & & 0,00320 & 7,187 & \\
\hline Quadrático do nitrogênio & $-0,000$ & & 0,00000571 & $-6,051$ & \\
\hline Linear da água & 0,001 & & 0,000206 & 4,901 & \\
\hline Quadrático da água & $-0,000$ & & 0,0000000229 & $-4,277$ & \\
\hline \multicolumn{6}{|c|}{$\begin{array}{l}\text { ** - Significativo ao nível de } 1 \% \text { de probabilidade. } \\
\text { * - Significativo ao nível de } 5 \% \text { de probabilidade. } \\
\text { NS - Não significativo. }\end{array}$} \\
\hline \multicolumn{5}{|c|}{$\mathrm{SSA}=0,792+2,30 \cdot 10^{-2} \mathrm{~N}-3,45 \cdot 10^{-5} \mathrm{~N}^{2}+1,01 \cdot 10^{-3} \mathrm{~W}-9,79 \cdot 10^{-8} \mathrm{~W}^{2}$} & $(24)$ \\
\hline
\end{tabular}

sendo SSA a quantidade de sólidos solúveis produzidos por árvore $(\mathrm{kg})$.

A superfície de resposta e as curvas de isoprodução estão apresentados nas Figuras 18 e 19, onde se observa a distribuição espacial dos dados estimados pela equação (24). A produção máxima estimada de sólidos solúveis é $6,42 \mathrm{~kg}$ /árvore, para um volume de irrigação de 5158,3 1/árvore e uma dose de nitrogênio de 333,3 g/árvore. A menor 
produção estimada é de 0,79 kg/árvore, na ausência de nitrogênio e irrigação. Neste caso, a diferença relativa entre os valores é $87,7 \%$.

A produção de sólidos solúveis por árvore foi mais influenciada pela produção de frutos por árvores do que pelo teor de sólidos solúveis por fruto. Isto pode ser observado ao se comparar Figuras 11 e 12 com 18 e 19. Segundo Koo (1979) a produção de sólidos solúveis por árvore pode aumentar com o acréscimo de nitrogênio ao solo, mas depende das condições climáticas, particularmente de chuvas no período de formação de frutos. Sharples e Hilgeman (1969) trabalhando com doses crescentes de nitrogênio, mostra que há uma relação direta entre a aplicação de nitrogênio e a produção de sólidos solúveis por árvores.

Confirmando os resultados deste trabalho, Koo (1979) aponta que o aumento das doses de nitrogênio e dos níveis de irrigação proporcionam aumento em sólidos solúveis totais produzidos por unidade de área. Entretanto, Hilgeman (1977) cita que a quantidade de sólidos solúveis por árvore é menor em pomares irrigados durante todo o ano relativamente a pomares submetidos a déficit hídrico no período de enchimento de frutos.

A padronização dos métodos de classificação de frutos para indústria de extração de sucos cítricos utiliza o teor de sólidos solúveis como o principal parâmetro de decisão. Entretanto, ao se tratar de reposição de minerais no solo deve-se considerar a produção física exportada. Por estas razões, o produtor de laranja deve avaliar tanto a produção física como a produção de sólidos solúveis totais, para planejar a produção e a exportação de minerais da área. 


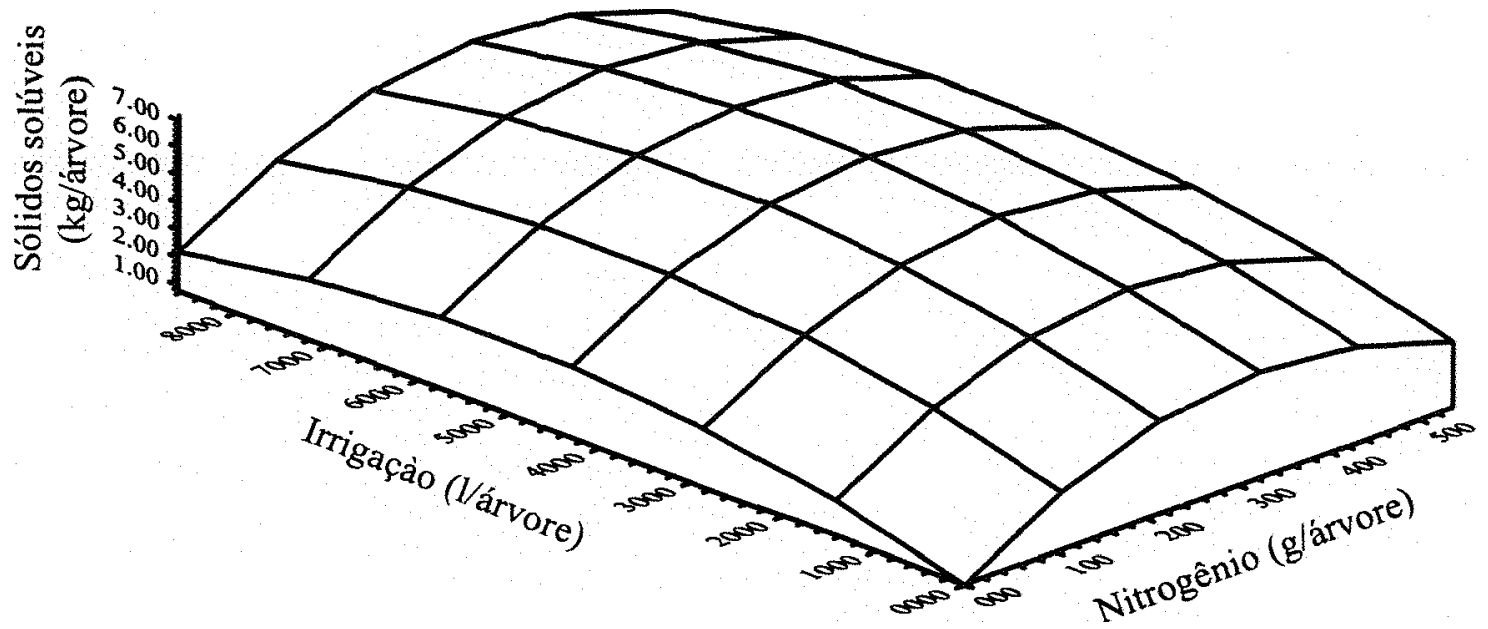

Figura 18. Superfície de resposta para sólidos solúveis produzidos por árvore em função da irrigação e adubação nitrogenada

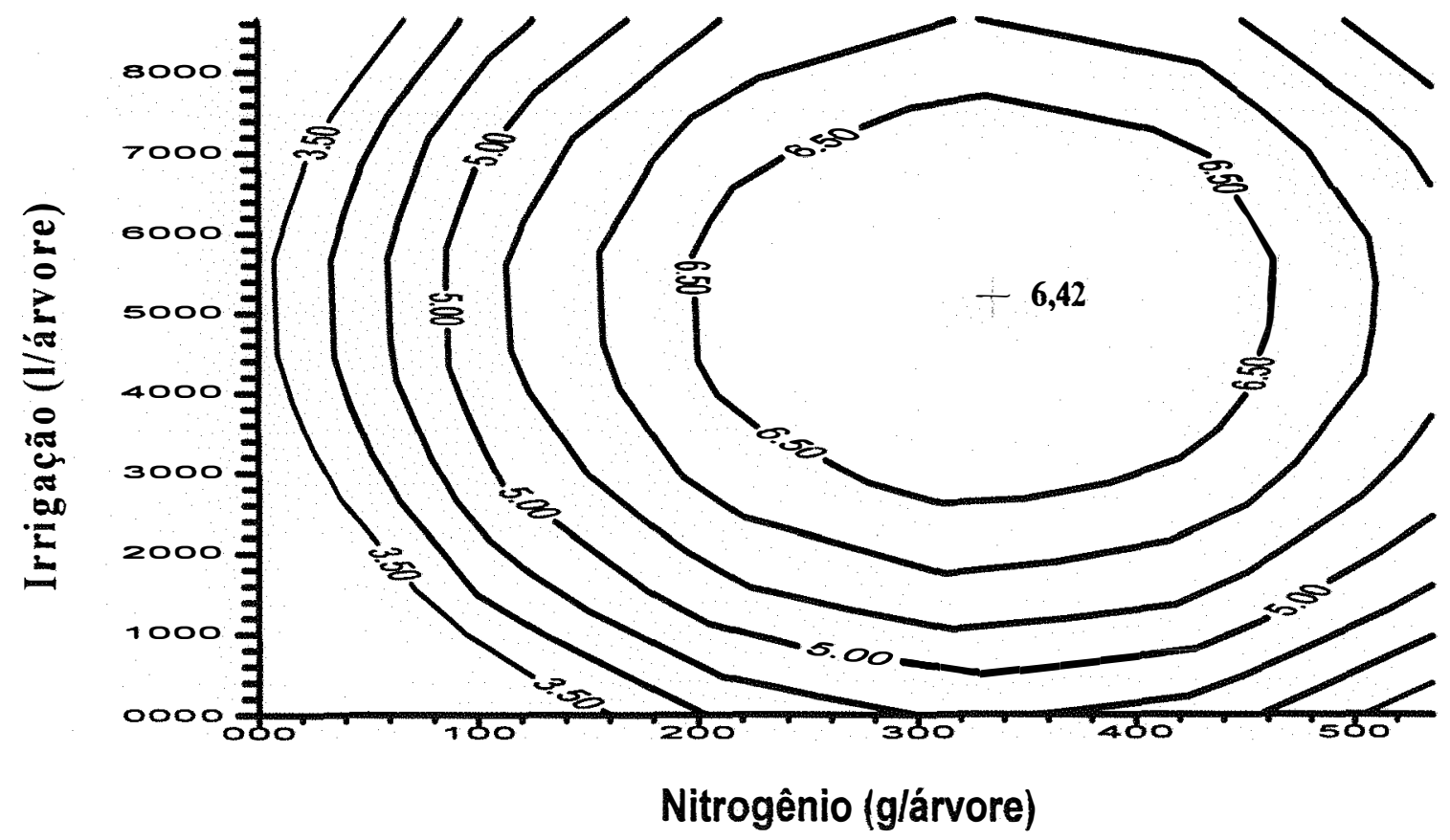

Figura 19. Curvas de isoprodução para sólidos solúveis produzidos por árvore em função da irrigação e adubação nitrogenada 


\subsection{Análise econômica do experimento}

\subsubsection{Custo da irrigação}

O custo fixo anual do equipamento de irrigação é $R \$ 0,6715$ por árvore, conforme apresenta-se na Tabela 20, considerando-se o pomar utilizado para este trabalho, com 360 árvores por hectare. O custo variável, estimado pelo custo da energia elétrica para cada tarifa, foi calculado em função dos volumes de irrigação, considerando-se a demanda e o consumo de energia. Ao custo variável foi acrescentada a tributação de ICMS (Imposto sobre circulação de mercadoria e serviços) de $18 \%$ (Tabela 21).

Para irrigar um hectare com os volumes $W_{3}, W_{4}, W_{5}$ e $W_{6}$ com a potência instalada de $0,981 \mathrm{~kW}$ são necessárias mais que 8 horas de operação. Para aplicar tais volumes foi feita a composição de tarifas que inclui a utilização da mais barata, durante 8 horas de operação (horário reservado), e da imediatamente maior para o restante da operação.

Tabela 20. Custo fixo anual do equipamento de irrigação.

\begin{tabular}{lcc}
\hline \multicolumn{1}{c}{ Itens } & & Valor (R\$/árvore) \\
\cline { 1 - 1 } Juro anual sobre o capital empregado & & 0,1667 \\
Depreciação anual do sistema de irrigação & & 0,4215 \\
Custo anual com reparos e manutenção & & 0,0833 \\
Total & & 0,6715 \\
\hline
\end{tabular}


Tabela 21. Custo anual da energia elétrica para as várias opções de tarifas oferecidas pela CPFL, em função dos volumes deirrigação utilizados no experimento.

\begin{tabular}{cccccc}
\hline $\begin{array}{c}\text { Trat. de } \\
\text { irrigação }\end{array}$ & $\begin{array}{c}\text { Irrigação } \\
\text { (l/árvore) }\end{array}$ & Verde & $\begin{array}{c}\text { Monômio } \\
\text { convencional }\end{array}$ & $\begin{array}{c}\text { Benômio } \\
\text { convencional }\end{array}$ & $\begin{array}{c}\text { Azul } \\
\text { fora de pico }\end{array}$ \\
\hline $\mathrm{W}_{1}$ & 1440 & 49,25 & 4,80 & 60,61 & 52,40 \\
$\mathrm{~W}_{2}$ & 2880 & 50,83 & 9,60 & 63,78 & 57,13 \\
$\mathrm{~W}_{3}$ & 4320 & 53,45 & 16,80 & 69,05 & 61,85 \\
$\mathrm{~W}_{4}$ & 5780 & 58,18 & 28,81 & 78,55 & 66,58 \\
$\mathrm{~W}_{5}$ & 7200 & 62,90 & 40,80 & 88,05 & 71,31 \\
$\mathrm{~W}_{6}$ & 8640 & 67,63 & 52,81 & 97,55 & 76,03 \\
\hline
\end{tabular}

Os menores valores do custo da energia elétrica foram conseguidos com a utilização da tarifa monômio convencional (Tabela 21). Havendo necessidade de maior potência instalada ou tempo diário de operação, o usuário pode optar por qualquer outra tarifa ou composição entre elas. A tarifa monômio convencional não apresenta custo de demanda, por isso seu preço é mais favorável.

Os custos da irrigação por árvore, em função dos volumes de água, estão apresentados na Tabela 22 e a variação dos mesmos na Figura 20 . O valor $\mathrm{R} \$ 0,6715$ corresponde ao custo fixo do sistema de irrigação por árvore.

Verifica-se na Tabela 22, que o custo total da irrigação correspondeu a 83,7; 85,3; 87,$8 ; 91,9$ e $95,9 \%$, respectivamente para $W_{1}, W_{2}, W_{3}, W_{4}$ e $W_{5}$ em relação a $W_{6}$.

Os volumes de água $\mathrm{W}_{1}$ e $\mathrm{W}_{2}$ podem ser aplicados exclusivamente durante $\mathrm{o}$ período de 21:00 às 5:00 horas (horário reservado), por exigirem menos que oito horas de irrigação por hectare. Os demais volumes de água exigem mais que 8 horas de irrigação e, portanto, não podem ser aplicados apenas no período de horário reservado. 
Tabela 22. Volumes de irrigação, custos fixos, variáveis e totais ( $\mathrm{R} \$$ árvore), durante o ciclo de produção.

\begin{tabular}{|c|c|c|c|c|}
\hline \multirow{2}{*}{$\begin{array}{l}\text { Trat. de } \\
\text { irrigação }\end{array}$} & \multirow{2}{*}{$\begin{array}{l}\text { Volume de } \\
\text { Irrigação } \\
\text { litros/árvore }\end{array}$} & \multicolumn{3}{|c|}{ Custos do serviço da irrigação (R\$/árvore) } \\
\hline & & fixo & Variável & Total \\
\hline $\mathrm{W}_{0}$ & 0 & 0 & 0 & 0 \\
\hline $\mathrm{W}_{1}$ & 1440 & 0,6715 & 0,0133 & 0,6848 \\
\hline $\mathrm{W}_{2}$ & 2880 & 0,6715 & 0,0267 & 0,6982 \\
\hline $\mathrm{W}_{3}$ & 4320 & 0,6715 & 0,0467 & 0,7182 \\
\hline $\mathrm{W}_{4}$ & 5760 & 0,6715 & 0,0800 & 0,7515 \\
\hline $\mathrm{W}_{5}$ & 7200 & 0,6715 & 0,1133 & 0,7848 \\
\hline $\mathrm{W}_{6}$ & 8640 & 0,6715 & 0,1466 & 0,8181 \\
\hline
\end{tabular}

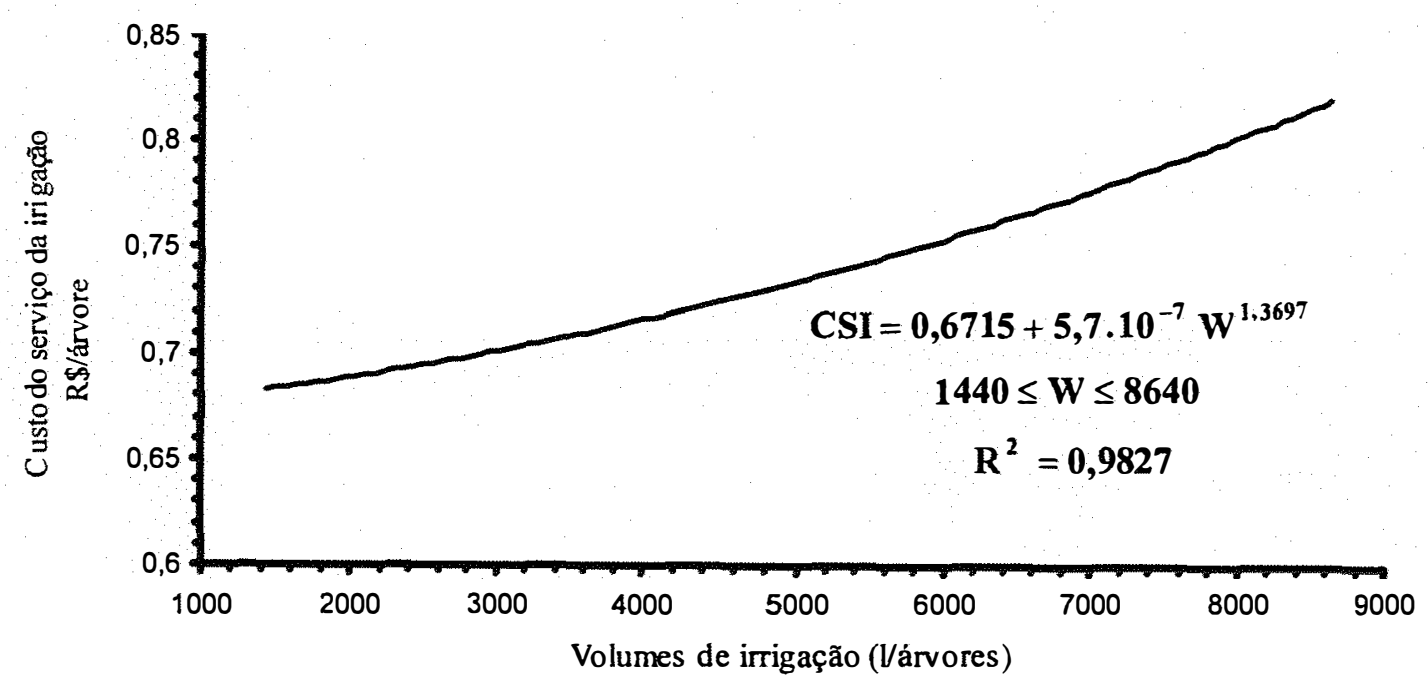

Figura 20. Custo da irrigação em função dos volumes de irrigação aplicados.

Para os volumes $\mathrm{W}_{3}$ e $\mathrm{W}_{4}$ o tempo de operação do sistema foi de 9 e 12 horas respectivamente para atender as três unidades operacionais. Por isso utilizou-se a tarifa convencional (fora de pico) em 1 e 4 horas de operação respectivamente, além das 8 horas de operação com a tarifa de preço reduzido. 
Nos volumes $W_{5}$ e $W_{6}$ o tempo de operação do sistema foi 15 e 18 horas respectivamente para atender as três unidades operacionais, sendo necessário a utilização da tarifa convencional em 7 e 10 horas de operação, além das 8 horas de operação com a tarifa de preço reduzido.

\subsubsection{Custo anual do pomar}

O custo anual do pomar para o $5^{\circ}$ ano foi estimado em $\mathrm{R} \$ 3,61 /$ árvore (Tabela 23), dos quais $\mathrm{R} \$ 0,55 /$ árvore corresponde a amortização do capital investido $(15,2 \%)$ e $\mathrm{R} \$$ 3,06/árvore corresponde ao custeio $(84,8 \%)$.

Das despesas do $5^{\circ}$ ano ( $\mathrm{R} \$ 2,75 /$ árvore) $28,2 \%$ foram empregadas com máquina e equipamentos, $12,1 \%$ foram destinados ao pagamento de mão-de-obra e $59,7 \%$ à compra de insumos (Tabela 4). Ainda relativo a essas despesas, R\$ 1,80/árvore foram gastos com defensivos e herbicidas dos quais $64,2 \%$ com máquinas e equipamentos, 59,2\% com mãode-obra e $68,3 \%$ com insumos. Verifica-se que os gastos com defensivos e herbicidas são 2,6 e 2,2 vezes maior que o custo do serviço de irrigação para os volumes $W_{1}$ e W6, respectivamente.

Altos custos totais do pomar no $5^{\circ}$ ano ocorreram nos tratamentos $\mathrm{W}_{4} \mathrm{~N}_{2}$ e $\mathrm{W}_{4} \mathrm{~N}_{3}$, os quais apresentaram as maiores produções físicas (Tabela 24). Isto destaca o custo da colheita na composição do custo total do $5^{\circ}$ ano. 
Tabela 23. Custo anual do pomar, no $5^{\circ}$ ano (R\$/árvore).

\begin{tabular}{lc}
\hline Discriminação dos valores & $\mathrm{R} \$$ \\
\hline Despesas totais do $5^{\circ}$ ano (Custeio) & 2,73 \\
Juro sobre as despesas do $5^{\circ}$ ano (12\%aa) & 0,33 \\
Depreciação do capital investido & 0,25 \\
Juros sobre o capital investido (21anos) & 0,30 \\
Custo anual do pomar, por árvore, no $5^{\circ}$ ano & 3,61 \\
\hline
\end{tabular}

Tabela 24. Custo total do pomar no $5^{\circ}$ ano (R $\$$ /árvore)*.

\begin{tabular}{lccccccc}
\hline $\begin{array}{l}\text { Níveis de } \\
\text { nitrogênio }\end{array}$ & \multicolumn{7}{c}{ Volumes de água (Várvore) } \\
\hline (g/árvore) & W0 (0) & W1 (1440) & W2 $(2880)$ & W3 (4320) & W4 (5760) & W5 (7200) & W6 (8640) \\
\hline N0 (0) & 4,60 & 4,89 & 4,97 & 5,41 & 5,10 & 4,99 & 4,74 \\
N1 (107,5) & 5,26 & 5,48 & 5,49 & 6,00 & 6,53 & 6,56 & 6,24 \\
N2 (215) & 5,71 & 5,79 & 6,01 & 6,73 & 6,91 & 6,38 & 6,55 \\
N3 (322,5) & 6,00 & 5,87 & 6,30 & 6,39 & 6,85 & 6,46 & 5,72 \\
N4 (430) & 5,91 & 6,69 & 6,42 & 6,86 & 6,76 & 6,44 & 6,47 \\
N5(537,5) & 5,80 & 6,51 & 6,31 & 6,96 & 6,86 & 6,54 & 6,15 \\
\hline
\end{tabular}

* Incluem nos cálculo os custos da colheita e do nitrogênio aplicado.

\subsubsection{Receitas}

A receita bruta relativa à produção de frutos destinados ao consumo in natura (Tabela 25), foi estimada ao preço de $\mathrm{R} \$ 3,00 / \mathrm{cx}$, utilizando os valores de produtividade observados. Aos preços cobrados pelas indústrias ( $\mathrm{R} \$ 1,80 / \mathrm{cx}$ ), não foi apresentada a análise econômica por resultar em receitas líquidas negativas em todos os tratamentos.

Os valores da receita líquida da colheita do $5 .^{\circ}$ ano estão apresentados na Tabela 26. Esses foram obtidos a partir dos valores observados de produção de caixas de frutos por árvore. A função de receita líquida por árvore é expressa pela equação (25), considerando o preço médio do mercado de frutas in natura. 
Tabela 25. Receita bruta por árvore, frutos para consumo in natura (R\$3,00/cx)

\begin{tabular}{|c|c|c|c|c|c|c|c|}
\hline \multirow{2}{*}{$\begin{array}{l}\text { Níveis de } \\
\text { nitrogênio } \\
\text { (g/árvore) }\end{array}$} & \multicolumn{7}{|c|}{ Volumes de água (l/árvore) } \\
\hline & W0 (0) & W1 (1440) & W2 (2880) & W3 (4320) & W4 (5760) & W5 (7200) & W6 (8640) \\
\hline N0 (0) & 1,50 & 2,70 & 3,00 & 4,80 & 3,30 & 2,70 & 1,50 \\
\hline N1 $(107,5)$ & 3,90 & 4,80 & 4,80 & 6,90 & 9,00 & 9,00 & 7,50 \\
\hline N2 (215) & 5,40 & 5,70 & 6,60 & 9,60 & 10,20 & 7,80 & 8,40 \\
\hline N3 $(322,5)$ & 7,50 & 6,90 & 8,70 & 9,00 & 10,80 & 9,00 & 5,70 \\
\hline N4 (430) & 5,40 & 8,70 & 7,50 & 9,30 & 8,70 & 7,20 & 7,20 \\
\hline N5 $(537,5)$ & 4,50 & 7,50 & 6,60 & 9,30 & 8,70 & 7,20 & 5,40 \\
\hline
\end{tabular}

A receita líquida máxima estimada pela equação (25) foi $R$ \$ 2,67/árvore por ano, para o volume de irrigação de 5067 1/árvore e dose de nitrogênio de 322 g/árvore. O maior prejuízo foi de $\mathrm{R} \$ 3,58$ /árvore por ano, tendo ocorrido na ausência da adubação nitrogenada e de irrigação suplementar.

Tabela 26. Receita líquida por árvore para o mercado de frutos in natura (R\$árvore).

\begin{tabular}{lccccccc}
\hline $\begin{array}{l}\text { Níveis de } \\
\text { nitrogênio }\end{array}$ & \multicolumn{7}{c}{ Volumes de água (l/árvore) } \\
\cline { 2 - 8 } (g/árvore) & W0 (0) & W1 (1440) & W2 $(2880)$ & W3 (4320) & W4 (5760) & W5 (7200) & W6 (8640) \\
\hline N0 $(0)$ & $-3,10$ & $-2,19$ & $-1,97$ & $-0,61$ & $-1,80$ & $-2,29$ & $-3,24$ \\
N1 $(107,5)$ & $-1,36$ & $-0,68$ & $-0,69$ & 0,90 & 2,47 & 2,44 & 1,26 \\
N2 $(215)$ & $-0,31$ & $-0,09$ & 0,59 & 2,87 & 3,29 & 1,42 & 1,85 \\
N3 (322,5) & 1,50 & 1,03 & 2,40 & 2,61 & 3,95 & 2,54 & $-0,02$ \\
N4 (430) & $-0,51$ & 2,01 & 1,08 & 2,44 & 1,94 & 0,76 & 0,73 \\
N5(537,5) & $-1,30$ & 0,99 & 0,29 & 2,34 & 1,84 & 0,66 & $-0,75$ \\
\hline
\end{tabular}

Na figura 21, estão apresentadas as isoquantas de receitas líquidas, em função da irrigação e da adubação nitrogenada. 


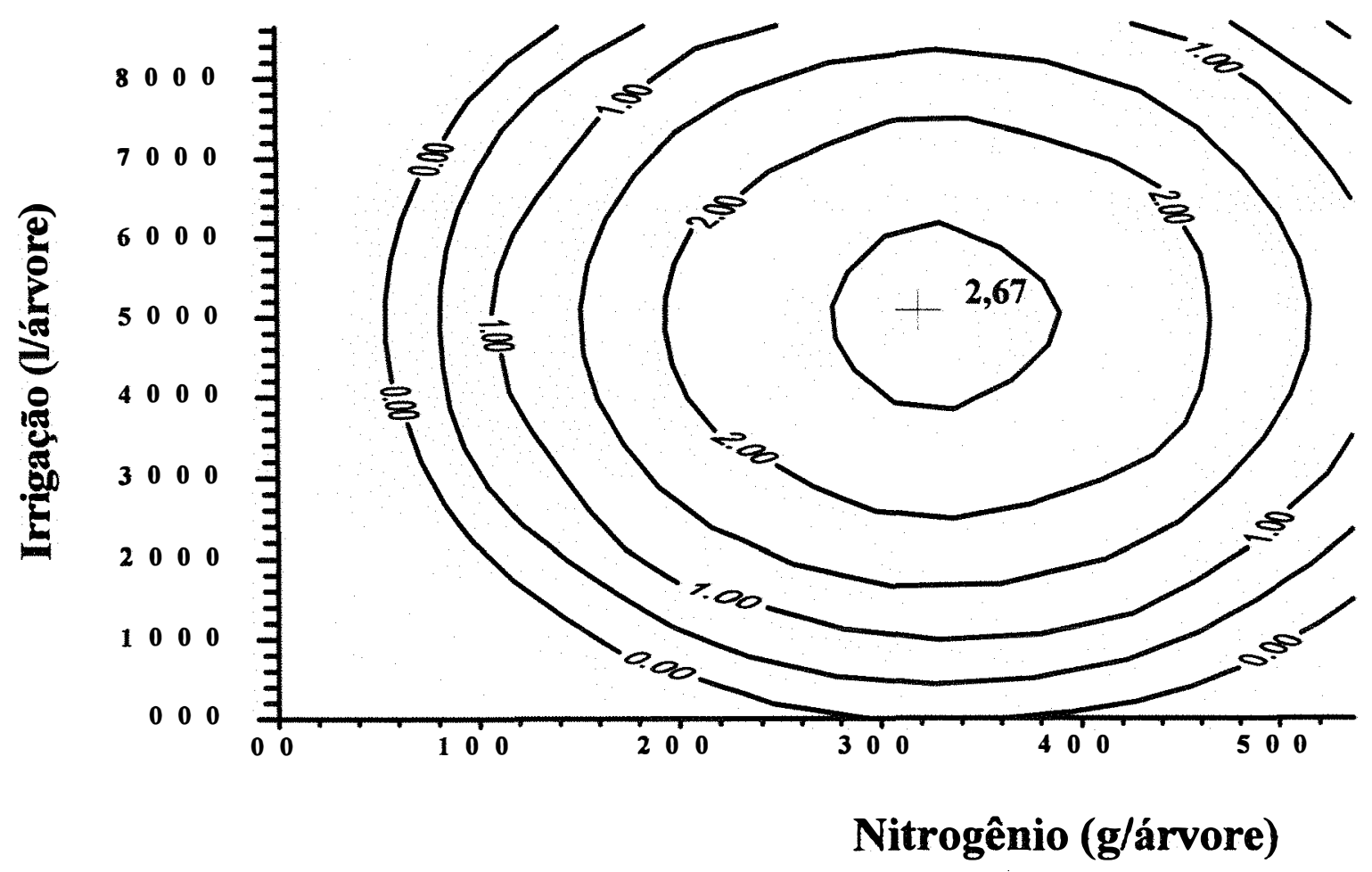

Figura 21. Isoquantas de receitas líquidas em função da irrigação e da adubação nitrogenada.

Observa-se na figura 21 que o volume de água necessário para maximizar a receita líquida foi próximo do volume de água necessário para a produção máxima (5067,0 e 5095,6 1/árvore, respectivamente) e qua a quantidade de nitrogênio necessário para maximizar a receita líquida também foi próxima da quantidade necessária à produção máxima (322,0 e 345,9 g/árvore, respectivamente). 


\section{CONCLUSÕES}

a) O número de frutos colhidos por árvore apresentou uma relação quadrática em função do volume de irrigação e da adubação nitrogenada, atingindo o máximo quando aplicados 4851,71 de água e $245,7 \mathrm{~g}$ de $\mathrm{N}$ por árvore.

b) O peso médio do fruto aumentou uma relação quadrática com nitrogênio e linear com água, atingindo o máximo quando aplicados $364,2 \mathrm{~g}$ de $\mathrm{N}$ por árvore.

c) O número de caixas de frutos produzidos por árvore teve maior correlação com o número de frutos que com o peso médio do fruto.

d) A produção de caixas de frutos por árvore apresentou relação quadrática em função da aplicação de nitrogênio e água, atingindo o máximo quando aplicados 5095,6 1 de água e $345,9 \mathrm{~g}$ de $\mathrm{N}$ por árvore.

e) Irrigação e adubação nitrogenada possibilitaram o aumento simultâneo do número de frutos por árvore e do peso do fruto. 
f) Aplicação de doses crescentes de nitrogênio aumentou o volume de seco por fruto e diminuiu o teor de sólidos solúveis.

g) Teores de sólidos solúveis superiores a 10\% foram obtidos com doses de nitrogênio menores que 337 g/árvore, independente do volume de irrigação.

h) $\mathrm{O}$ volume de suco produzido por árvore seguiu uma relação quadrática em função dos níveis de irrigação e nitrogênio, atingindo o máximo quando aplicados 50201 de água e $360,5 \mathrm{~g}$ de nitrogênio por árvore.

i) A quantidade de sólidos solúveis por árvore apresentou relação quadrática em função da irrigação e da adubação nitrogenada, atingindo o máximo quando aplicados 5158,31 de água e 333,3 g de nitrogênio por árvore.

j) Irrigação complementar e adubação nitrogenada possibilitaram obter receitas líquidas positivas em pomares de cinco anos, produzindo frutos para consumo in natura. 


\section{REFERÊNCIAS BIBLIOGRÁFICAS}

BARREDA D. G.; LEGAZ, F.; PRIMO, E.; LORENZO, E.; IBAÑEZ, R. E TORRES,V. Irrigation of Young WE. Navel CV. Frost Trees. In: INTERNATIONAL CITRUS CONGRESS, 6., São Paulo, 1984. Proceedings. São Paulo: International Society of Citriculture, 1984. v.2, p.121-123.

BESTRER, H. D.; FOUCHÉ, P. S. e VELDMAN, G. H. Fertilizing through drip irrigation systems on orange trees. In: INTERNATIONAL CITRUS CONGRESS, 1., 1977. Proceedings: Intenational Society of Citriculture. v.1, p.46-49. 1977.

BIELORAI, H ; DASBERG, S. ; ERNER, Y. E BRUM,M. The efect of fertigation and partial wetting of the root zone on producion of Shamouti oranges. In: INTERNATIONAL CITRUS CONGRESS, 6., São Paulo, 1984. Proceedings. São Paulo: International Society of Citriculture, 1984. v.2, p.118-120 
BOSCH, D. J. ; EIDMAN, V. R. ; OOSTHUIZEN, K. A review of methods for evaluating economic eficiency of irrigation. Agricultural Water Management, v.12, n.2, p. 231-245. 1987.

BRITO, R. A. L. Irrigação plena e suplementar nos cerrados do centro-oeste de Minas Gerais. In: CONGRESSO NACIONAL DE IRRIGAÇÃO E DRENAGEM, 8., 1988, Florianópolis: ABID/CIC, 1988. p.139-160

BRITO, R. A. L.; SCALOPPI, E. J. Estimativas de cusot da irrigação por aspersão no Brasil. In: CONGRESSO NACIONAL DE IRRIGAÇÃO E DRENAGEM, 7., Brasilia, 1986. Anais. BRASILIA, ABID, 1986. v. 3, p. 879-898.

CASTRO P. R. C. Comportamento dos citrus sob díficit hídrico. Laranja, v. 2, n. 15, p. 139-154, 1994.

COELHO, A. M. Balanço de nitrogênio $\left(\mathrm{N}^{15}\right)$ na cultura do milho (Zea maiz, L.) em um latossolo vermelho escuro fase cerrado. Lavras, 1987. 142p. Dissertação (Mestrado)Escola Superior de Agricultura de Lavras. 
COELHO, A. M. , FRANÇA, G. E. , BAHIA FILHO, A.T.C. Dinâmica do nitrogênio em um latossolo vermelho escuro fase cerrado cultuvado com milho sob irrigação. Sete Lagoas EMBRAPA/CNPMS, 1991.

COELHO, R. D. Regulagens de aspersores e seus efeitos sobre a uniformidade de aplicação de água e produtividade das culturas. Piracicaba, 1990. 141p. Dissertação (Mestrado) - Escola Superior de Agricultura "Luiz de Queiroz", Universidade de São Paulo.

COELHO, S.T. Matemática financeira e análise de investimentos. São Paulo: Ed. Nacional, Edusp, 1979. 279p.

COHEN, A. e GOELL, A. Fruit developement as an indicator of the irrigation needs of citrus trees. In: INTERNATIONAL CITRUS CONGRESS, 6., São Paulo, 1984. Proceedings, São Paulo: International Society of Citriculture, 1984. v. 2, p. 114 a 117.

COLWELL, J. Estudos dos efeitos do solo e clima sobre a resposta de culturas a fertilizantes. In: CONTINI, E. ; ARAÚJO, J. D. de; OIVEIRA, A. J. ; GARRIDO, W. E., ed Planejamento da propiedade agrícola: modêlos de decisão. Brasília: EMBRAPA, 1984. p. 67-100. 
CUENCAS, R. H. Irrigation system desing: An engineering approach. New Jersy: Prentice Hall, 1989. 551p.

DOORENBOS, J. ; KASSAN, A. H. Yield resposte to water. Roma: FAO, 1979. 193p. (Irrigation and Drainage Paper, 33).

DOORENBOS, J. ; PRUITT, W. O. Crop water requeriments. Rome, FAO, 1977. 144p. (FAO. Irrigation and Drainage Paper, 24).

ECKERT, J. B. ; CHUDRHRY, N. M. ; QURESHI, A. A. Water and nutrient response of semi-dwarf wheat under improved managment in Pakistan. Agronomy Journal, v.10, n.70, p.77-80, 1978.

ENGLISH, M. J. Deficit irrigation. I: Analitical framework. Journal of the Irrigation and Drainage Engineering, v.166, n.3, p.399-412. 1990.

ENGLISH, M. J. ; NAKAMURA, B. Efect of deficit irrigation and irrigationfrequency on wheat yields. Journal of the Irrigation and Drainage Engineering, v.115, n.2, p.172-184. 1989. 
FEICHTENBERGER, E. Gomose de Phytophthora dos citrus. Laranja, v. 11, n. 1, p. 97-122, 1990.

FOOD AND AGRICULTURE ORGANIZATION OF THE UNITED NATIONS. FAO

Yerbook Anuaire Production. Roma: FAO, 1995. 233p. (FAO Estatistic Série, 130).

FRIZZONE, J. A. Funções de respostas do feijoeiro (Phaseolus vulgaris L.) ao uso de nitrogênio e lâmina de irrigação. Piracicaba, 1986. 133p. Tese (Doutorado) Escola Superior de Agricultura “Luiz de Queiroz",Universidade de São Paulo

FRIZZONE, J. A. Funções de respostas das culturas à irrigação. Piracicaba: ESALQ. 1993. 53p. (Série didática 006).

FRIZZONE, J. A. ; ZANINI, J. R. ; PEREIRA, G. T. ; REITORE, P. R. Efeito da frequência e da lâmina de irrigação na produção de trigo (Triticum aestivum L.). Ciência e Prática, Lavras, v.9, n.2, p.198-207. 1985.

GARCIA, A. Nova análise da citricultura brasileira nos anos noventas. Laranja, v.l, n. 14, p. 1-43, 1993. 
GAZZOLA, R. ; OLIVEIRA JUNIOR, J.P.; et al. Correlação entre características químicas e físicas nos frutos de laranjeira (Citrus sinensis L. Osbeck c. Natal). Ciencia e prática. $\mathrm{n}^{0} 15$, v.2, p. 154-158. abr./jun. 1991.

GIORGI DI, F., YASUHIRO, B. , KELSON DIB, I.. , MARCHI, R. J. , TRIBONI, H.R.., WAGNER, R.L. , ANDRADE, G. Influência climática na produção de laranja. Laranja, v. 1, n. 12, p. 163-192, 1991.

GIRITON, R. E. The Growth Of Citrus Seedlings As Influenced By Enviromental Factors. University of California Agriculture Siencie. v.5, P.83-117, 1927.

GUARDIOLA, J. L. Fruit set and growth. In: SECOND INTERNATIONAL SEMINAR ON CITRUS, Bebedouros, 1992. Proceedings. São Paulo: International Society of Citriculture, 1992. v.2, p 121-123.

VITTI, G. C. Nutrition and growth of citrus plants. In: SECOND INTERNATIONAL SEMINAR ON CITRUS, Bebedouros, 1992. Proceedings. São Paulo: International Society of Citriculture, 1992. v.2, p 139-158.

HAAG, H.P.; GUTIERREZ, A.R.; DECHEN, A.R. Variação de matéria seca e de nutrientes nas folhas e nos frutos, produção de ácidos ascórbico e suco, em seis 
cultivares de citrus, durante um ciclo. Scientia Agrícola, n50, v.2, p.193-203, jun./set.1993.

HANKS, R. W. Model for prediciting plant yield as influenced by water use. Agronomy Journal, v.66, p.660-665. 1974.

HARGREAVES, G. H. ; SAMANI, Z. A. Economic considerations of deficit irrigation. Journal of Irrigation and Drainage Engineering, v. 110, n. 4, p. 3343-3358, 1984.

HART, W. E. ; NORUM, D. I.; PERI, G. Opitimal seasonal irrigation aplication analysis. Joural of the Irrigation and Drainage Division, v.106, n.3, p.221-235, 1979.

HAXEM, R. W. ; HEADY, E. O. Water production funcion for irrigated agriculture. Ames: The Iowa State University Press, 1978. 215p.

HILGEMAN, R. H. Response of Citrus Trees to Water Stress in Arizona. fertilizing through drip irrigation systems on orange trees. Proceedings. International Society of Citriculture, 1977. v.1, p.70 a 74, 
HOWEL, T. A. ; HILER, E. A. Organization of water utilization through multiple crops scheduling. Transactions of the ASAE, v.18, n.2, p. 293-2978. 1975

IANNINI P. L. Mercado interno de frutas cítricas, Laranja, v.2, n.13, p.165-188, 1992

INSTITUTO AGRONÔMICO DO PARANÁ. Cartas Climáticas Básicas do Estado do Paraná. Londrina; IAPAR, 1978. 35p.

KELLER, J. ; BLIESNER, R. D. Sprinkler and trickle irrigation. New York: Van Nostrand Reinhold, 1990. 651 p.

KOO, R.C.J The influence of $\mathrm{N}, \mathrm{K}$ and irrigation on tree size, and fruit production of "valencia" orange. Proceedings. Florida State Horticulture Society, v. 92, p. 10 a 13. 1979. (Florida Agricultural Experiment Staqtions Journal Series $n^{0} 2122$ ).

KOO, R.. C. J. , YOUNG, T.W., REESE, R.L., KESTERSON, J.W. Effects of nitrogen, potassium and irrigation on yield and quality of lemon. Journal of. America Society of. Horticulture Science. v. 99, n. 4, p.289-291, 1974.

KOO, R. C. J. e REESE, R.L. Influence of nitrogen, potassium, and irrigation on citrus fruit quality..In: International Citrus Simposium, 1., Orlado, 1977. Proceedings. 
Orlado: International Society of Citriculture,. 1977. v.1, p.34-38. (Florida Agricultural Experiment Sations Journal Series n ${ }^{0} 579$ )

KOO, R. C. J. Results of citrus fertigation studies. Proceedings. Florida States of Agriculture Society,. v.93, p.33-36. 1980

LABANAUSKAS C. K. ; LETEY, J. ; KLOTS, L.J. E STOLZY, L.H. Influence and irrigation and soil oxygen on the nutrient content of citrus seedlings. California Agricultura, p. 12-13, 1966.

LIMA, J. E. Devemos ou não expandir o plantio de citrus?. Laranja, v.1, n.14, p. 137 $148,1993$.

MAGALHÃES, A. C. Considerações sobre a fisiologia do sistema radicular: o caso das plantas cítricas. Laranja, v.2, n.9, p. 401-404, 1988.

MALAVOLTA, E. ; SILVA, A. Q. ; CESAR, M. J. A. ; TEOFILO SOBRINHO, J. ; PONPEU JUNIOR, J. Variação de matéria seca e de macronutrientes nos frutos de cinco variedades de citrus durante o seu crescimento. In: CONCRESSO BRASILEIRO DE FRUTICULTURA, 7., Florianópolis, 1984. Anais. Florianópolis: Sociedade Brasileira de Fruticultura, 1984. p. 424-434. 
MALAVOLTA, E \& VIOLANTE NETO, A. Nutrição mineral, calagem, gessagem e adubação dos citrus. In: III SIMPÓSIO DE CITRICULTURA, 3., Jaboticabal, 1988. Anais. Jaboticabal: Fundaçào de Estudos e Pesquisa, 1988, p.233-281

MARIN, M. R. G.; PEÑA, E. P.; MORENO, S. F. M. E SOTEL, F. V. Analisis economico do sistema de riego por goteo. In. SEMINÁRIO LATINOAMERICANO SOBRE RIEGO POR GOTEO, 3., Campinas, 1968. Anais. Campinas, 1968. P. 554578.

MARSH, A. W. Irrigation. In:Walter Reuther. The Citrus Industry . University of California, 1968. v. 3, pg 230-279.

MAZZA, J. A. e VITTI, G. C. Influência da compactação no desenvolvimento do sistema radicular de citrus: sujestão de métodos qualitativo de avaliação e recomendação de manejo. Laranja, v. 2, n.15, p. 263-276, 1994.

MOREIRA, C. S. Manejo de solo em pomar cítrico. Laranja, v.2, n. 9, p. 423-436, 1988. 
MUNGOMERY, W.V. ; JORGENSEN, K.R. ; BARNES,J.A. Rate and timing of nitrogen apllication to Navel oranges: efectcs on yield and fruit quality. In: INTERNATIONAL CITRUS CONGRESS,., Brisbane, 1984. Proceedings. Brisbane: International Society of Citriculture, 1978. p.285-288.

NEVES, E. M , ANDIA, L. H. , NEVES, M. F. \& PONPEU, R. B. Análises comparativas de cusos de laranja para a indústria: São Paulo (Brasil) e Flórida (EUA). Laranaja , v. 1, n. 14, 1993.

NEVES, E. M.; SHIROTA, R. Considerações sobre a importância, determinação e atualização dos custos agrícolas. Programa de treinamento BANESPA, Piracicaba, FEALQ, 1986. 23p.

NORONHA, J. F. Teoria da produção aplicada à análise econômica de experimentos. In: CONTINI, E.; ARAÚJO, J. D. de; OLIVEIRA, A, J.; GARRIDO, W. E. , ed. Planejamento de propriedades agrícola: modelo de decisão. Brasilia: EMBRAPA , 1984. P. 23-65.

ORPANOS P. I. ; ELIADES G. Nitrogen fertigation of valencia orange irrigated by drip minisprinkler. In: INTERNATIONAL SYMPOSIUM ON CURRENT DEVELOPMENTS IN MEDITERRANEAN TROPICAL AND SUBTROPICAL 
FRUIT PRODUCTION AND RESEARCH, Nicosia, 1992. International society for horticultural science. Acta Horticulturae 1994, p.105-120

PALACIOS-VELES, H. Response functions of crops yield to soil mouisture stress. Water Resource Bulletin, Minneapolis, v. 17, n. 4, p. 699-703. 1981.

PARSONS, L.R. ; MURARO, R.P. Economics of cirus irrigation. In: INTERNATIONAL CITRUS CONGRESS, Proceedings. International Society of Citriculture, 1991. p. 148-151.

PAZ, V, P, da S. Condições ótimas de operação de sistemas de irrigação por aspersão. Piracicaba, 1995, 125p. Tese (Doutorado) - Escola Superior de Agricultura "Luiz de Queiróz", Universidade de São Paulo.

PERES, J.R.R., SUHET, A.R. Adubação nitrogenada no planalto central. In: REUNIÃO BRASILEIRA DE FERTILIDADE DO SOLO, 16., Ilhéus, 1995. Anais. Sociedade Brasileira de Ciências do Solos. Ilhéus: CEPLAC; SBCS, 1986. p. 221242.

PIRES, R.C.M. Manejo da água na irrigação de citrus. Laranja, v. 1, n. 13, p. 237-260, 1992. 
PLESSIS DU, S.F. ; KOEN, T.J. Effect of nutrition on fruit size of citrus. In: INTERNATIONAL CITRUS CONGRESS，6., São Paulo，1984. Proceedings. São Paulo: International Society of Citriculture, 1984. v.2, p.148-152.

REICHARDT, K. Processos de transferências no sistema solo planta atmosfera. Campinas: Fundação Cargill, 1985. 486p.

RODRIGUÊS, O. Nutrição e adubação de citrus. In: RODRIGUÊS, O.; VIÉGAS, F.C.P. Citricultura Brasileira. Campinas: Fundação Cargill, 1980. p. 385-428.

SHARPLES, G.C.; HILGEMAN, R.H. Influence of differential nitrogen fertilization on production, trunk growth, fruit size and quality and foliage composition of "Valencia" orange trees in central arizona. Proceedimgs. International. Citrus Symposium, vol.3, p.1569-1578.

SMIKA, D.E. Nitrate-N percolation through irrigated sandy soil as afected by water management. Agronomy journal, v.69, p. 623-626, 1977. 
SOLOMON, K. H. Typical water production funcion. In: WINTER MEETING, AMERICAN SOCIETY OF AGRICULTURE ENGINEERS, Chicago, 1985. Paper 85-2596. Chicago: American Society of Agriculture Engineers, 1985, p. 17-20.

STARK, J.C. , JARRELL, W.N. , LETEY, J. Evoluation of irrigation - nitrogen managemente pratices for celery using continuous- variable irrigation. Soil Science Society of America Journal, v.47, p.95-98, 1983

STEGAMAN, E. C. ; MUSICK, J. T. ; STEWART, J. I. Irrigation water management. In: JENSEN, M. E., ed. Design and operation of farm irrigation systems. St. Joseph: American Society of Agricultural Engineers, 1980. p.763-816. (ASAE Monograph n.3).

SUHET, A.R. , PERES, J.R.R., VARGAS, M. A. T. Nitrogênio. In: GOEDERT, W. J. Solos de cerrados; tecnologia e estratégias de manejo. São Paulo: Nobel, 1985. p. 167-202.

TUBELIS, A. ; SABILE, A. A. Efeito da chuva na produtividade da cultura de laranja "Baianinha ". Laranja, v. 1, n. 12, p.141-156, 1991.

TUBELIS, A. Clima: Fator que afeta a produção e a qualidade da laranja. Laranja, v. 2, n.16, p. 179-212, 1995. 
VILLIERS, J. I. The effect of diferencial fertilization on the yield, fruit quality and leaf composition of navel orange Proceedings International Citrus Symposiun. v. 13, 1969.

VERMEIREM, I. ; JOBLING, G. A Localized Irrigation, Food and Agriculture organization of the united nations. Rome 1986. 203 p.

VITTI, G. C. Nutrition and growth of citrus plants. In SECOUND INTERNATIONAL SEMINAR ON CITRUS, Bebedouro, 1992. Proceedings. São Paulo: International Society of Citriculturer, 1992. V. 2, p. 139-158. 